\title{
A N N A L S
}

or TII:

\section{NEW YORK ACADEMY OF SCLENCES,}

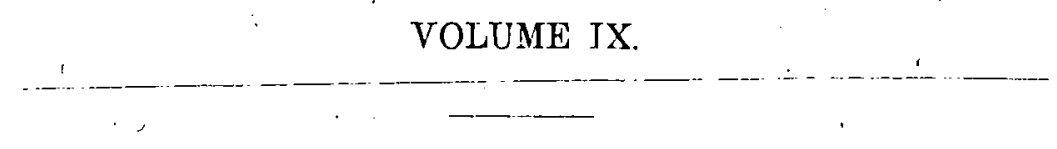

I.-The Craspedosomatide of North Ancrica.

BY O. F. (OOK AND G. N. COLLINS.

Rend October 7, 16ji).

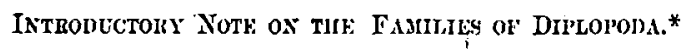

Since the completion of the paper on North American Craspedosomatidie many dissections and drawings of representatives of , other families of Diplopoda have been made, resulting in the apprehension of more light on the affinities of the group here treated. Among the forms studied are Striaria, Stemmatoiulus, Cambala, Cambalopsis, Nannolene, Pseudonannolene, Lysiopetalum, Paromopus, Siphonophorn, Siphonoutus, Siphonorhinus, Spirostreptus, Spirobolus, Parninlus, Pseudoiulus, and numerous representatives of the Polydesmoidea. The resnlt of this examination is opposed to the opinion of Pocock, Latzel and Berlese, that the present family is allied most closely to the Inlidx. It seems more reasonable to place the Craspedosomatida next to the Polydesmidie and to arrange the families of Diplopoda as follows :

\section{Class DIPLOPODA.}

Subclasg PEELAPHOGNATHA.

$\cdots$, Order Ancyrotricha.

Fomily Polyxexid $x_{2}$-genern Polyxenus and Lophoproetus.

Distribution: Cosmopolitan.

* By O. F. Cook.

ANnaLs N. Y. ACAD. SCr., IX, Oct., 1895.-1 


\section{Oriler Lophotricha.}

Fimily PALAOCAMPID), - - genus Palæocampa.

Distribution: A fossil from the enrboniferous Mazon Creck beds, Illinois.

\section{Subclass CHILOGNaTHa. Order Onlscomorpha. \\ Subrder GLoseromes.}

Family GLowenine, - genera, Glouncris, Jatzelia (preoceupied by a fossil chilopod.)

Distribution: Europe, Asia and North Africa.

Family Gerkatsum k, grenus Gernaisia.

Distribution: Europe.

Suborder ZNPHRONIOIDEA.

Family Zepirnosims, - penem Zephionia, Sphieropens, Spherotherium.

Distribution : South $\Lambda$ frica and Southern $\Lambda$ sir.

Orier Limacomorpha.

Suborler GLONERIIESMOINFA.

Fumily Gronerumenun.t,-genus Glomeridesmus.

Distrilution: South America and the West Indies.

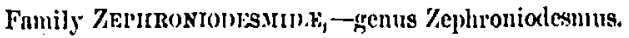

Distribution : Sumatra.

\section{Order Colobognatha.}

Sulworler I'oury NoIDris.

Family Pousosind,-genera Polyzonium, Platyzonium, type P. gclschmannii (Cryptodesmus getsclmamii Karsch.)

Distribulion: North tempernte regions of both hemispheres.

Family Siphoxotrn), - genera, Brellotus, type B. formosis (Siphonotns formosus, Pocoke), lihinotus, type $R$. africtum (Siphonotus africanus, Cook), Siphonotus.

Distribution : Tropies of both hemispheres.

This and the previons family may constitute a superfnimily Polyzonoida, equivalent to the superfamily Siphonophoroida:

Fanily Srliroxopilomula,-genera Bactrois, type B. villatus (Siphonophora vittatn, Pocock), Siphonophom.

Distribution: Tropies of both hemispheres.

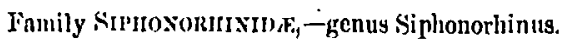

Distribution: 'l'ropies of both hemispheres. 
Suborder Pl.ATYNesioned.

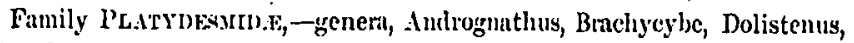
Platydesmus, Pseudalesmus.

Distribution: North America, Wurope and Asia.

Suborder SIPHONOCRYITOIDEA.

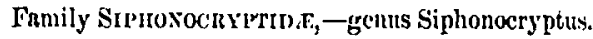

Distribution : Sumatra.

Oriler Monocheta.

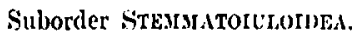

Fumily StensatomuLind, -genus Stemumatoinlus.

Distribution:- -1 lyppics-of-both-hemispheres.

Suborcler Xriontomed.

Family Xruottum.3,-genus Xyloiulus (Tylobius Do:vson).

Distribution: A fossil from the Sigillarian stumps of the carboniferous beds of Nown Scotin.

Order Merocheta.

Sulorder IASIOPETALOIDEA.

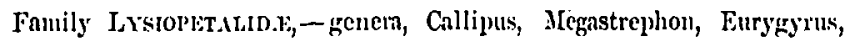
Iysiopetalum, Spirostrephon.

Distribution: North Temperate Zone.

Suborler Craspenosomatomal.

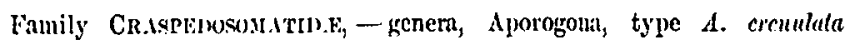
(Craspedosoma crenulatum, Lat\%el), Atractosoma, Attemsia, type A. stygic (Istzel), Aulacosoma, Bactropus, Basigona, tyje B. athesinu (Fedrizzi), Bomogona, type B. lomburlica (Brolemann), Branneria, Chelogona, type C. corputhica (Iatzel), Cascya, Chorleuma, Clcidogrona, * Conotyla, Cirspleclosoma, Grypogona, type fi. leizrli (Atractosoma latzeli, Verlund), Haasia, Haplogona, $\dagger$ type $H$. oculodislimela (Verhof), Mastigona, $†$ type dr. mutabilis (Iat\%el), Melogoun, type גe. rhemum (Chordeuma gallicum var, rhenanum, Verhoff), Sycogona, type Br. gormanica (Chomienum germanicum, Verhoff), Sonogona, type $N$. polydesmnilles (Leach), Ochogona, type 0. purilla (Atractosoma pusillum, Verhurff), I'hanogona, type $I$ 'h. loh'micr (Rosicky), P'sendotremia, Khiscosona, Scoterpes, Truchygona, + 'Trichopetalum, Underwoolia, Xiphogona, $\dagger$ type X. flaresces (Iatzel), Kigronopus.

Distribution: North 'lempernte regions and New Zealnnd.

* Cleidogrona is propeserl for Cryptotrichus I'ackari, procecupieal in Coleoptera.

t'These three names take the places respectirely of Latzelin, lomtia and Hasea, proposed by Verhu'f in recent numbers of the Zoülogisclier Anzeiger, but all preoceupied in Diplopola,- - Intzelia twice.

† For Traclyysoma, recently proposed by $A$ ttems but preoceupied in Crastacen. 
Family Hetrnochondeusmin,e,-genern Heterochorleuma, Pocockia.

Distribution: Ceylon and Sumatra.

Family Strinmide, -genus Striaria.

Distribution: Temperate North America.

Suborder POLydesworden.

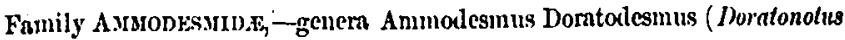
Pocock, pre-oceupied).

Distribution: Tropical Africa and Asin.

Family A toodfsirns, - - genern Augolesmus, Euryurus, Polylepis.

Distribution: Tropical A merica.

Family C.umpodssmine,-genera Campodesmus, Cyrtollesmus.

Distribution: Tropical A frica and America.

Family Cireronesmin.r,-genem Chelodesmus, * Leptodesmus, Odontopeltis, Odontotropis, Prioflesmus, lhachorlesmus (Rhachis, is pre-occupied), Strongylorlesmus.

Disiribution: Tropical A merica.

Family Cryptonesmids,-genera Aporodesmus, Cryptoilesmoides, Cryptodesmus, I'oratia, Trichopeltis.

Distribution: Tropics of both hemispheres.

Family CxcLon:syide,-genus Cyclorlesmus.

Distribution: Tropical America. There seems to be little ground for supposing that the Malayan genus Doratouotus is related to the Mexican genus Cyclodesmus.

Fanily Gostprodrsminx,-genera Astrodesmus, Aulodesmus, Gomphodesmus, Harmodesmus, Marptolesmus, Sphenodesnus, Tycodesnus.

Distribution: East 'Troplical Africa.

Family Hupxodessure,-genus Haplolesmus (Haplosoma Verhof, preoccupied).

Distribution: Amboina.

Fanily Oxisconesside, - genera Cyphodesmus, Oniscodesnuus, Sphæriodesmus.

Distribution: Tropical A merica.

Fanily Oxydrsmins, -genera Anibodesmus, Isolesmus, Minodesmus, Orodesmus, Oxydesmus, Scytodesmus, 'Tylodesinus.

Distribution: Tropical Africa.

* Pores 13, on segiments $5,7,9,10-19$, latero-inferior; sternum of fifth segment of inale with four processes, that of the sixtl with two; male legs with a large process from the apex of the penultimate joint. Type Chelodesmus marrii, U. S. National Museum. 
Family Paradoxosomatids,-genern Parniloxosoma, Trachydesnus.

Distribution: Corfu.

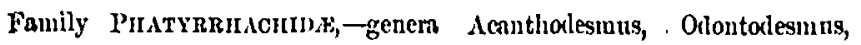
Platyrrhacus, Trachelolesmus.

Distribution: Tropics of both hemispheres.

Family PoLydesminde,-genern Brachyilesmus, Chrotaspis, Goniolesmus, type C. fusilobus (Polydlsmus fissilobus, Brolemann), Polydlesnuts, Scy tonotus. . Distribution: Temperate Kurope, $\Lambda$ sin and North $A$ merica.

Fanily Stronayuosomatide, - genern Anoplotesinus, Centrodesmus, Cne-

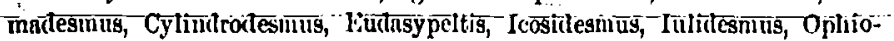
desinus, type 0 . verkrifi (Strongylosomum verhutfi, Brolemann), Orthodesmus, Prionopeltis, Rhachidomorpha; Strongylosoma, Tetracentrosternus, Trogodesmus.

Distribution: Cosmopolitan, mostly Tropical.

Fanily Styodesmidx,-genen Cynelesmus*, Lophodesmus, Pyrgolesmus, Styloriesmus.

Distribulion: Tropics of both hemispheres.

Fannily Xrstodrsyrd.F,--genem Eurydesnus, Fontaria, Pachydesmus, type P. crassicutis (Wood), Rhysodesmus, type R. limntr (Sauss.), Stenodesmus, Xystodesmus, type $\mathrm{X}$. mertensii (Peters).

Disiribulion: North America and Easterll Asia.

Order Diplocheta.

Suborder S1'IROSTuEPTOHNA.

Family Sprnosturimrid, E, genern Alloporus, Archispirostreptus, Ctenoitulus, Odontopyge, Plusioporus, Rhynchoproctus, Spirocyclistus, Spiropeus, Spirostreptus, Thyrolygus.

Distribution: Tropics of both hemispheres and South Africn.

Family Trucrystubrids,-genem 'Tu(hystreptug, type \%' cambaloidcs, $\dagger$ Lophostreptus, type L. magnus (Kansch).t

Distribution: Tropical Africit.

* Type Cynclesmus formicola, U. S. Sational Museum; the genus also includes" $C$. ornamentalus (Cryptolesmus ornamentatus, Karsch).

†Trachystrephus crmbalfuils sp. n.-Wearly hlack; antenme strongly clarate, lying in lateral conenvities of the first segment; heal, first and last segments closely punctate; other segments with numerous irregular cariniform Iongitudinal ritges. Segments $37-39$. I.ength $25 \mathrm{~mm}$.; wiltli $2.2 \mathrm{~mm}$. IIahitat, Liberia.

$\ddagger$ I hove exnmined the type of Cilyphinlus magmus Karsch, in the Berlin Muselim. 
Suborler Casibaromsia.

Family Pseudoxaxnolexids,-genus l'seudomannolene.

Distribuion: South America.

Family Naxxolwsind,-genera Namolene, Iulomorpha.

Distribution: Western North America and South Africa.

Family Cammands, -genus Cimbala.

Distribution: Eastern North Ainerica.

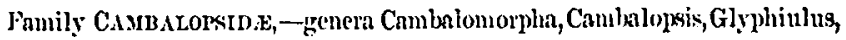
Trachyinlus, Trichocambsia.

Distribution : Sonthem $\Lambda$ sia.

Family Arcurnutud.e,--genera Archüulus, Archicambnla, type A. densoni (Xylobins dawsoni, Scutder).

Distribution: Fossils from the Sigillarian stumps of the carboniferous beds of Nova Scotia.

\section{Suborler IULorvts.}

Fumily Iucin.t, - grenera Allaiulus, Anaulaciulus, Brachyiulus, Chromatoinlus, Cryptoiulus, Cylimlroiulus, Diploinlus, Jiemipodoiulus, Iulus, Mesoiulus, Micropoliulus, Padyiulus, Palicoiulus, Tnchypodoiulus, Typhloitulus, Lnciger, Xestoiulus.

Jistribution : North 'Tempernte \%one.

Family Pardminds, -genera Paniulus, Pscudoiulus, Ptyoiulus, type $P$. ponusylcanicus (Bmolt).

Dislribution: 'Temperate Yorth America.

Family Promordos,-genus Picromopus.

Dislribution: California.

Family Braxichine,-genus Blaniulus.

Distrilution: Enrope.

Fanily Ison.tтux, -gemus Isolhites.

Distribulion: Europe and Temperate North America.

Suborder Sirnoxotutromki.

Family Siproxoruldef, 一renus Siphonoiulus. *

Jislribulion: Sumatra.

* This most remarkable form is probably worthy of orlinal rank and might lo called Rlinoguatloa. The alsence of legs from the thircl and fouth segments indicates want of allinity with the: Colologmatha, while the form of the heal and antenne will doubtlesy exclude it from the Iiplocheta. 
Orier Anocheta.

Sulorder Sprironotombis.

Fanily Sironor,me,-genen dcanthiults, Rhinocricus, Spirobolellus Spirololus, Thyroproctus, Trigoniulus.

Distribution: 'Tropics of hoth hemispheres.

Sullelass ARCHIPOIYPODA.

Family Lupromsrin,e,-with numerous genera.

This group is an assemblage of widely different fossil forms, some of which will probably prove to be true Chilognatha; this

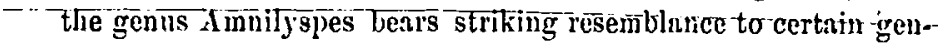
era of Polydesmoiclen. The species of Euphoberia and Acantherpestes, however, are types apparently very distinct from the Chilognatha. The six dorsal setie are located as in Craspedosomatilu, while the setere and unpaired seminal duct are both present in Stemmatoiulus, the representative of $n$ order equal in antiquity to the Archipolypoda, so that the derivation of the Chilognatha from the A rchipolypoda is not indiented by present evidence, though a common origin is most probable.

The orders and families of Chilognatha are in need of enreful description which will make the labor of charticterizing species and genera less difficult. In all the suborders, except the Polydesmoidea, the assignment of the genera to the different families is made with some confidence. The classifieation of the Polydesmoiden is in a backward state, owing to the fact that the older writers neglected many of the more important characters and the arrangement of some of the genera may prove to be more or less artificial and provisional.

The character which during our study of the Craspedosomatida we supposed to be unique among recent Diploporla-the dorsal seta-is shared by Stemmatoiulus, which has even the curious setiferons papille of the last segment, though there are four in Stemmatoinlus, and only two in Craspedlosomatide. The co-cxistence in Stemmatoinlus of pores and setwe show that the presence or absence of cither of these structures is not of itself evidence of close aflinity or wide diversity. The stpposition that the spines are in some way a substitute for the repugnatorial apparatus is also shown to have no foundation.

The presence of exterual seminal ducts in Inlida and their absence in Craspednsomatida is at once an important and an easily 
stated dingnostic character, and has been used in the following synopsis of orders. So various are the adnptations of legs in different parts of the body to assist in copulation, that the weight of the principal distinction on which the group Oniscomorpha rested has its relative importance somervlint diminished. Others of its characters are evidently coördinations with its habit of rolling into a sphere, and are not necessarily to be interpreted as evidences of a diversity of origin.

\section{Synopgis of Orders of Chilocinatifa.}

Böry conposel of not more -than-13-distinct-segruents; male_copnlatory organs seremal-jointel, situnterl at the posterior end of the booly.

\section{Orter Onigcomorpha}

Body composed of at least 19 segments.

Males with the legs of the seventh segment unmolified; external seminal ducts long, divaricnte, beset with whorls of setne... Order Inlmacomorpha Iales with one or both pairs of legs of the seventh segment transformed into copulatory organs.

Males with eight prirs of legs in front of the 4-5-jointed copulatory organs, which replace the posterior pair of legs of the seventh segment and the anterior pair of the eighth; seginents 1-5 each with a single pair of legs. Orler Colobognatha

Males with seren pairs of pre-copulatory lens; copulatory organs not more than 2-jointed, replicing one or both jairs of legs of the seventh segment.

External seminal apertures appearing as perforations of the coxe of the second pair of legs................................ Oriler Merochota

Coxic of second male legs imperforate.

Labrum with a median sinus; segments 1-5 with one pair of legs each; external scminal ducts wanting, the apertures located at the bise of the second pair of legs................... Order Anocheta

Iabrum with a metion tonth; segment 3 or 4 footless; external sominal ilucts present.

Pleurc entirely obliternted; legs 7-jointed; external scminal apertures throurh paired, unjointed; external ducts inserted at the base of the second male legr............ Order Dlplocheta

l'leura ncarly flee; legs 8-jointel; external senimal aperture single, through a :-jointed external duct inserted at the base of the sicond mule legs. Order ifonooheta

\section{Notes on Síchnens and Types.}

As Lysiopetalidia and Chordeumidre the American species of this family have been subject to more revision than those of ally 
other. W.e concluded, however, after attempting a study of the forms occurring in central New York, that more complete descriptions of the known species would be necessary for their identification and an understanding of their generic relationships. Especially undesirable would be the projection of the new species into the existing confusion.

Through the kindness of Drs. Riley and Gilbert we were permitted to examine the types in the National Museum and the collection of the University of Indiann. These, with our own collection, gave us examples of nearly all the described species.

Unfortunately the types of the species described by Wood, Pnekard, Cope, Ryder and Harger nre not accessible, and may be no longer in existence. Dr's. Cope and Ryder expressed their regret at being unable to assist us, as their specimens could not be found. Dr. Packard favored us with a vial of specinens of Pseudotremia and stated that his material may have been deposited in the Museum of Comparative Zoölogy, at Cambriige. Owing to the illness of Dr. Hagen we conld not get necess to the specimens, nor ascertain whether they are in the Muscum. The Museum of the Philalelphin Academy of Sciences contains but one-species of this family, a Cryptotrichus, but not Wood's type.

A study of the material at hand soon showed us that we had entirely underestimated our task; it purported to consist of twelve of the fourteen species then known, but from it we have been compelled to erect seven additional species. Collections male by ourselves added four more, and when this paper was nearly finished Captain Casey presented a bottle of California Myriapoda among which we found still another novelty, increasing to twenty-eight the number of species known from North America. From this it may be inferred that many species are still to be discovered, especially since the distribution is usually very local. Individuals are scarce, and require the most cneful collecting in very moist habitats where species of other families are not commonly found, and which are therefore not visited except in special quests for Craspedosomatidx.

Our thanks are due to Mr. R. Innes Pocock, of the British Muscum, for many kindnesses in the way of opportunity of examining the collections under his charge, and for specimens of European Craspedosomatidie which have enabled us to verify our opinion of their generic distinctness from American forms. 


\section{Notes on Habits and StRucture.}

'The habits of living Craspedlosomatidixe slow considernble diflerence from those of other fanilies, and emphasize the importance of some structurnl characters which have, we think, not received proper weight in classification.

Reference is made chiefly to Trichopetalum, * which on account of its abundince, small size and transparent exo-skeleton is well suited for observation. But so much alike are all the members of this family, that there is probably little difference with regard to considerations of habits or structure, with the exception of litck of cyes in cave forms.

In central New York T'richopetalum is onc of the most common and generally distributed of Diptopoda, thongh linbte-to-he-overlooked on account of its small size. Like the other members of this fimily it inhabits rather wet places, but does not seem particular in other respects, living among mosses and rotting lenves, and under sticks and pieces of bark.

When undisturbed the grat of Trichopetalum is quite leisurely, but when friglitened it never attempts to protect itself by coiling up, relying on its powers of flight. 'lhis course is warranted by the fact that the Craspedosomatidie are more fleet of foot than other Chilognatha, though some species of Yulidac are able to. progress at a very respectable pace. It is also noteworthy that the flecter species of Iulicla (Paraiulus) are not inclined to coil up when frightened, but attempt to rum, and even when captureri and held they do not at first employ the ruse of coiling up and feigning deatl, but attempt to escipe by vigorous wriggling. All Iulidie seem, howerer, to have the power of coiling up, and will sooner or later exercise it for protection.

The alsility to coil up rlepends on a certain form and structure of the segments. The dorsal part must be longer than the ventral, and the anount one segment overlaps the next must be greater in the form that is able to coil up. There is also necessitated a Iarger sunount of flexible integument between the segments.

The I luicie manifest all these characters, even to the flattening of the pedal laminse and the basal joints of the legs; other Chilognatla bave them, usially in a less clegree.

\footnotetext{
"The species deveribed in this perper ay Trichnetalum alhum.
} 
In the Craspedomatida, however, the clorsal and ventral portions of the segments differ less in length, and although the pedal lamina have no chitinized connection with the pleura, the body is not coiled in a close spiral. Even when tightly contracted in alcohol, Trichopetalum and its allies are able to do little more than form a circle, a position of cloubtful use as a means of defense, especially when compared with the close spirals which Inlidlæ assume. The Craspedosomatida lack, besides, the strong exo-skeleton and repugnatorial secretion of the other families, so that for them coiling up would not have much advantage as at means of defense.

$\Lambda \mathrm{s}$ might be inferred from the preceling statements the instinct of feigning deaih is not developed in Craspelosomatidis. While they are ate they attempt to-run-away, but if lield in the hitud the heat and drier ntmosphere are soon fatal. This was noticed especially in Undervoodia polygama. If held in the hand and exposed to sunlight they were soon unable to rim in the ordinary wa, wriggled convulsively a few times and died. This would happen in a minute or two, while the specimen was being exnmined with a leus to determine the sex. In such cases care wats taken to see whether the animals would recover, but they did not do so.

Individuals of Trichopetalum are also of very delicate organization. They will not endure captivity to any such extent as other Chilognatha, and will speedily die under conditions apparently furorable to the other families. Dryness of the atmosphere is quickly fatal, and the animals scem to suffer if the rentilation is insuflicient, eren thongh the moisture is adequate.

On the other hand, it slould be mentioner that a specimen of Conotyla fischeri was found running about on a log one morning in February, when the ground was frozen and the cold severe enongh to have covered with ice-crystals both the ground and the under sicie of the loy. Such thility to withstand the cold appenred repy strange at the time, and on investigation it was found that beetles and spiders under the log were incapalle of motion, though they recoverel after beiug warmed in the hand. The Conotyla wns not, however, under the log, but on the upper side of it, apparently ruite as lively and vigorous as during the warner parts of the year, showing that he had been able to withstand the cold of the Febiuary night and either keep lively 
through it or recover his powers at a temperature considerably below the freezing point. This can be understood if we mny suppose that these animals lave means of obtrining and using larger amounts of oxygen than other tracheata, and are more warm-blooded. In accord with this supposition is the following observation on Trichopetalum by $D_{1}$. John $\Lambda$. Ryder, several times verified by ourselves.

"While examining some living specimens of Trichopetalum lunatum under the mioroscope, abont a year since, I observed that the respiration of the animal appeared to be conducted in a most singular manner. The air seemed to be drawn in under the labrum, and in some way to enter the dorsal cardiac sinus as bubbles, which could be traced for some distance, more than half the length of the animal, as they traveled slowly backwards, until they disappenred orer the opnque mass of ingested food contained in the intestine. Thêse bubbles of air always passed backwards. It may be that they passed backwards inside of the intestine, bnt the impression that I got was that they were tiaveling through the cardinc sinus or dorsal heart of the animal. This circum. stance may explain why it is that there are no pores on the side of the boly, though it is true that the lateral pores af millipeds are usually 'foramina repugnatoria,' ancl have nothing to clo with the trachen or respiratory apparatus. This raises the question whether on! Lysiopetalidie are not distinguished from other forms in some more important way than lias been hitherto supposecl."

In connection with this ability to withstand cold should be mentioned the fact tliat in Europe the Alpune species aflecting the highest altitucles are Craspedosomatidr.

The eyes are well developed in Trichopetalum, though the ocelli are only moderately numerous. That is, the individual ocelli are large, promineut and convex, as is usual in the fanily, which has eyes apparently better developed than in other Diplopodn, and not flat or-merely pigmented spots as in other cases. But the type of eye seems to be the same as in the Iulidse and other families, and the animals take no notice of anything in front until the antenne are in contrat with the object, indicating that in all probability, the eyes are nnable to form definite images, but are merely spots sensitive to light. Yet the animals do not appear to have as decided objection to light as members of other 
fnmilies. When a specimen of Triclopetnlum is uncovered no perturbation is apparent unless, the animal is actually touched.

Not only do the antenna come in contact with an object, but also as a usual thing, the front of the head. The crentures are not able to overcome their momentum with sufficient quickness, or else their mental operations are too slow. They are not, however, worse off than mnny animals of higher organization, and better developed sense-organs, for many reptiles and mammals do not, as a rule, turn out for an obstacle until they have come into actual contact with it.

That the eyes of the Diplopoda aie incapable of forming images is, however, chicfly to be inferred from their plan of structure, as Lubbock has pointed out. And with the flattened eyes of Iulidx and Polyzonide this is at once plain; but the eyes of Craspedosomatida are much more convex, regular and well-defined than those of the others, and appronch more nearly the condition where effective vision might be possible.

One of the-most-noteworthy-characteristics_of Irichopetalum exists in the great freelom of motion enjoyed by the head. In other families the hend is set more or less deeply into the first segment which is hollowed ont in front to receive it, and is consequently incrpalle of more than a slight motion. In such cases the hend is smaller, that is, narrower than the first segment; but in the Craspedosomatide the hend is much broader than the first segment, against which it is fastened as to a neck, and upon which it moves with considernble liberty in any direction.

In like manner the mandilulary stipes are in this fnmily exceptionally developed, and capable of rapid movement in the process of chewing. The movement of the stipes in chewing has not been noticed in other Diplopoda, though its absence we have in some cases observed.

The antenna are, in most species of the family, exceptionally slender, but do not noticenbly differ from the diplopod type. In Trichopetalum, however, they re shorter and somewhat clavate. They are manipulated in the usual manner, though thcir motions are more than ordinarily quick.

If the antenne are dipped into a liquid or touched against any thing that sticks to them they are at once cleaned in the moutl. How the animals manage to kcep the other parts of their bodies clean is an interesting question, for although they live in places 
where they would be likely to become soiled they are always clenn to a degree. But when not to be cleaned the antenne are frequently bent at the fourth joint and the end held nenr the mouth, for no renson apparent.

In males the posterior pair of legs of the seventl segment are two-jointed, the distal joint being thick and clavate, and curved up agninst the side of the borly. In walking, this modified foot which cannot tonch the ground, is waved back and forth in unison with the legs on either side. The copulntion of these animals has not been observed. but that this structure can liave any part in the process is hard to believe or imagine, and that it is to be looked' npon as a merely rudimentary structure seems more reasonable. In American Craspedo. somatida are foumd the trinsitional stages between the condition existing in the Polydesmida and Lysiopetaliden, where only the anterior pair of feet of the seventh segment have been modified for copulatory purposes, and the condition present in the Inlida and Polyonidix, where hoth pairs are thus modified. As mightit be expected, the nodfication in form and the modification in function are apparently taking place grrodually, and in the present case a part of the leg aids in copilntion while the rest waves idly, "from force of habit."

Even in the Crnsperlosomatide which do not have the usual six bristles of each segment well-(leveloped on the anterior part of the boly, as in Pseudotremin and Chordenma, the posterior median bristles of the last sergment are well developed and to all appenrances alike in all the species. They are curionsly modified, consisting of a cylindric, or slightly conic, enlarged base, from. the distal end of which projects a long, exceedingly slender, flexible bristle, or in this casc more properly a hair. This is sumciently stiff to remain nearly straight, but is much finer than the bristles of the preceding segments, and not brittle.

A ttachel to the ends of these bristles liave on sereral occasions been noticed fine threads like spiders' wob dragging out hehind the animals as they walked, that is in Trichopetalum. And in the living specimens it has also been noticed that these modified bristles were sometimes carried vertically, and in others were nearly horizoutal. The peculiar conformation of the bases of these bristles aml of the apical portion of the segment suggests the possibility that these bases are articulated with the segment, 
and that the animal may have the power of moving them at will, and the desirability of being thus able to move them becomes evident if they are supposed to be spiuning organs, while it would be useless if they lave no special function.

\section{Sfansh-Orgaxs and Prombatateat Structures.}

In the course of the systematic examination of the different forms it was necessary to mount above a hundred microscopic slicles. These gave opportunity for the exrmination of the more minute structures of the animals, sometimes uncler tolerably farorsble conditions. Following are noticel briefly the structures which came to our attention. Some of them seem not to have been previonsly recorded, and our notes may be of use when a histologic study of the group is attempterl.

\section{I.-Antennie.}

On the antemne are sereral types of more or less hair-like structures, all of which may prove to be sense-orgains.

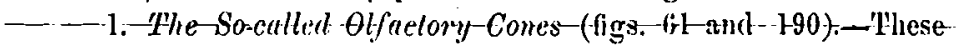
are well developed in all the species, the number being always four, as is the case in most Diplopocla. We have counted hun. drerls of specimens, including representatives of all the families, and have never fqund less than four. There are more than four cones in Glomeridie, some species of Spirobolus, and a genus of Polydesmidx from east Africa. 'The reports of one, two and three cones can he pardleled by the enrelessuess displuyed in counting the segments of Chilopoda.

The cones of Craspeclosomatide appent to differ from those of other families only in being more slender, more like a wine bottle in shape, and with longer bases.

2. Hairs of Ordinary Form.-Such may oceur on other parts of the body, and it is possible that all may have more or less of tactile function. Accorling to Sazepin's diagrams of the antenrixe of Iuliden and P'olydesmidre these hairs liare neural connection, and the same conditions scem to obtain in sections of the anteune of Conolyla fischeri.

3. At about the middle of the seventle joint, and pointing latterad when the antenne are extended, is a solitary, rather slender, mammillate-conic, transparent protuberance, narrowed at the tip and produced into a long, rery slender, and exceedingly fine- 
pointed hair. (figs. 61 and 190.) This structure is about the size of the olfatory cones, but histologically it is different, the contents of the enlarged base being cridently granular, instead of longitudinally fibrillate as in the cones.

Sazepin mentions nothing of this sort, and we have been unable to find anything similar on the antenne of Iulidre, Polydesmidre, Ly'siopetalidx or Polyzonidie. The structure in question is probably present in all Craspedosomatida, and may be looked upon as another evidence of the superior organization of this family. We have had no opportunity of examining the antenne of Scoterpes, but find it in all the other genern here treaterl.

4. On the same side of the same joint, just above the previously mentioned organ is a considerable number of long slender cones, differing from ordinary hairs in being thicker, and with a large internal lumen. The base inserted in the chitin is large and bulbous.

5. On all sides of the distal portion of the sixth joint are scattered transparent cones differing from the preceding sort in being somiew what bronder, with blunt rounded-ends- Thoy-ale-also-verythin-walled, the lumen being continued nenrly or quite to the end, and are not enlarged at base.

6. On the fifh joint, more numerous toward, but not confined to the distal portion, are structures very similar to the last, but differing in that they are longer, sharp-pointed, and of somewhat denser tissue. They differ from those of the seventh joint in being larger and longer and not enlarged at base.

7. On the distal portion of ench joint are hairs two or three times as long and large as the avernge. Similar hairs of other families are by Sazepin denominated "Schutzlaare," explaining their greater size by supposing them to be a special provision for the protection of the sense organs, near which they are locnted. They are probably articulated to the antennal surface, being surrounded by a chitinous ring at brse. That their role is not confined to what is mentioned above is shown by the fact that they occur on joints where there are no shorter sense-organs. $A$ lumen ean be seen extending throngh more than half the hair, the distnl portion of which is very slender and frequently flexuons.

The above structures are described from Conotyla fischeri. The same or equivalent seem to exist in other species, which do not, however, offer equal facility of observation. 


\section{I.-A Possible Auditory Organ.}

Between the base of the antenna and the neighboring ocelli is a ring-like elevation of the chitinous surface of the liear. We have been able to find this in most of the diplopod forrilies. In the Craspeclosomatida it is well-developed,-nearly as large as a single ocellus. Sometimes it appenrs that the surface included in the ring is coverel by a delicnte membrane, at others the appearauce is that of a dark central spot or aperture (fig. 133).

That the structure in question is a sense-organ appears very likely, but its function can only be conjectured. It is not impossible that it may prove to be an auditory organ. Certain species of Glomeridx, of the genus Spharotherium are known to lave stridulating organs, and in them, at least, an organ of hearing would be expected. That other diplopods stridulate is not known, and would seem unlikely. There have been also no experiments to determine whether they are able to hear, and such experiments would be very diflicult and probably unsatisfactory.

\section{$\mathrm{HI}=$ I'ke Labral Hairs.}

On the labrum is a transvere row of long hairs provicled in some forms, at leasl, with neural connections (fig. 194). These hairs do not nppenr to be especially differentiated in structure. They are placed in depressions, thongh this is not so much the ease in the present fanily as in the Inlidie. The best guess would probably be that they have merely tactile function. 'The number and arrangenent of the hairs is very constant.

\section{IV.-Gnathochilarium.}

1. Concs similar to those of the Antemne.-On the apjices of the processes of the stipes, and on the lingual lobes are more or less numerous conical structures resembling in a general way the socalled olfactory cones of the antenne (fig. 59). The fibrillated structure is still more apparent than in those organs, and the neural connections are very evident. They are also much shorter and proportionally bronder than the antennal cones, have thicker walls, and a more evidently hollow apex, the wall there being exceelingly thin. The size is very variable.

'lhere is no inherent improbability in the idea that these are

Axwaly N. Y. ACAn. Scr., IX, Oct., 1895-2 
also olfactory organs. They wonld enable the animal to detect substances suitable for fool, being always near the ground, and directly in front of the mouth. They are found in all Chilognatha, but in Craspedosomatidre are best developed. They are not so much as usual confined to the apices of the structures on which they are placed, occupying nearly the whole lateral edge of the exterior process of the stipes.

2. The interior Cone of the Lingual Lobes.-This is larger and longer than the others, directed mesal and somewhat curved in that direction. It is sharp-pointed and apparently of homogeneous strueture, no lumen being apparent. Its special function, if any, must be different from that of the other cones.

3. The Styliform Processes.--Near the anterior-interior coner of the lingual lamina is a peculiar, usually more or less tri- or quadri-dentate structure apparently consisting of a solid piece of chitin. This does not appear to exist in the other described families of diplopods, except in some Polydesnide (e. !., Scytonotus). We have no notion of any purpose it could serve.

4. The Bristles of the Gnathochilarium.-On the lower surfince and nitera edges of the gnathochilarium are a few hairs of greater size than the others, and with enlarged bases. They are probably tractile in function.

5. Probable Taste-pits.-The chitinous covering of the lingual lobe is on the superior side extended backward orer the ends of the lingual laminse. This extension consists of a chitinous rim enclosing an oral space covered by a transparent membrane in which are scattered numerous pits, each surrounded by a chitinous ring. 'These are slown in fig. 62 as they appenr in Conotyla fischeri.

$$
\text { F. The Dorsal Selo. }
$$

'These structures characteristic of the family are of transparent chitin, narrowly conic, with an enlarged bnse which fits into the socket of the setigerous tubercle. Sections show that the setre are hollow, and that the chitinous exo-skeleton is interrupted by an aperture in the middle of the socket.

The median pair of selx of the last seyment are different from the others in that there is a more brondly conic hase tipped with a slencler hair. The function of these may be different from that of the others, though what the function of either can be is hard 
to conjecture, unless they are spinning organs, as suggested in anotlier place.

In common with Polydesmida the anal valves of this fumily are provided with slenler bristles, but there are always three pairs instend of two, the constant number in Polydesmide.

The prennal senle lins two slender bristles, as in Polydesmidie. These are of the same form as those of the anal valves, have enlarged bases and may prove to be tactile organs; at loast this would be a rensonable inference in case neural connection can be proven.

$$
\text { VI.-Legs. }
$$

The legs are increasingly hirsute distad, some of the hairs being especially long and with enlarged bases, porhaps tactile organs. On the inner elge of the last joint of the first and sometimes of the second legs is a pectinate row of stout luairs or bristles; it may be these are of use in feeling or in cleaning the free and antenne.

The first legs have the claw large, and two distinct supplementary claws. The other legs usually have one supplementary claw.-She-otine-struetures-of the-legs are more properly to be noticed under the head of sexual characters.

On the claw of all the legs of Conotyla fischeri is a peculiar hair, which we have not found on otler species. The hair in question rises from the inferior groove abont midwny letween base and apex, and lies closely appressed to the claw, beyond which it extends as an oxceedingly fine, frequently flexwous filament, needing careful observation to be seen with a quarter-inch objective. When the animal is walking this hair necessarily comes first in contact with the ground and seems conveniently located for a tactile organ. It appears very remakable that the other species have no similar structure, but a careful search has failed to find it.

\section{VII.-Secondary Sexual Charracters.}

These are, as in other families of Diplopocla mostly confined to modiffentions of the anterior male legs. We give here a list of such modifentions, not inchuling those of the ninth male legs which are described under the different genera and species.

1. Body of males stouter and broader, especially segments six and seven, than that of females. This is not always noticenble, but is very evident in Cleidogona. 
2. Secoud legs strongly crassate, a charncter appenring only in Underwoodin.

3. Sccond legs nbnormally slender: Caseyn.

4. Coxæ of -second legs with a conic process: Zygonopus, or with a long curved or hamate process: Caseya, Lnderwoodia.

5. Third joint of second legs with a cushion-like bunch covered with conic processes : Conotyla.

6. Third joint of second legs tuberculate on ventral face: Caseya.

7. Lnst joint of second legs with a pectinate row of stout hairs on the imner edge: Conotyla, Cleidogona, and probably the other related genera.

8. Claw of second legs very sinall, much exceeded by a tuft of long flexuous hairs: Underwoodia.

9. Legs 3-7 strongly crassate : Trichopetalum, less so in most of the other genern.

10. Coxie of third legs produced into a rounded prominence with a tuft of hairs at apex : Caseya, Underwoodin.

11. Third joint of third legs much crassate: Underwoodia.

12. Last joint of third and many succeeding legs with the ven-

-. - tral foce hispit with line bayonet-like spines:-Conotyln, Cleidogonn, Pseudotremia.

13. Fourth joint of fourth and fifth legs with a cushion-like bunch corered with conic tubercles : Conotyla.

14. Sixth legs with coxa somewhat enlarged, and with a tuft of long hairs: Caseya.

15. Sixth legs strongly crassate: Zygonopus.

16. Seventh legs with coxa greatly enlarged, benring a conic process and tufts of hairs: Caseyat.

17. Coxn of seventh legs with a large tuberculate bunch on the posterior side: Conotyla (figs. 70 and 73).

18. Fourth joint of scventh leg with a proximally directed, apically quadridentate process: Conotyla fischeri (figs. 70 and 71).

19. Tenth and eleventh legs with the coxn perforate: Cleidogona, Pscudotremia, Conotyla. Sometimes a shapeless mass of membrane or lardened secretion projects from the aperture; perhaps this is what is described by Latzel as a wart-like process in European Chordeumidx.

20. Coxx of tenth male leg greatly enlarget and with a distal aperture: Caseya, Underwoodia (figs. 185, 210, 211). In Ca- 
seya there is a rounded projection from the rim of the opening, on the posterior side.

21. Coxe of eleventh leg with $\Omega$ lnrge conic process: Pseudotremia, Cleidogona. In Pseudotremin the process projects from near the base of the coxa, in Cleidlogona from the inidlle or above.

22. Eleventh and twelfth legs with coxa prominent, tuberculate: Conotyla.

23. Eleventh legs witli third joint proximally produced into a large, somewhat curved process : Conotyla.

24. Eleventh and twelfth, and probably the succeeding legs, tulberculate on the third and fourth joints : Caseyr.

25. Pedigerous lamina of twelfth legs with a large conic pro: cess directed ceplalad: Cleidogona Conotyla, Pscudotremia.

In addition there should be noted an aperture nenr the distal end of the second joint of the ninth legs of Cleidogona Inside the joint may be traced a duct or gland running nearly its whole length. In one monnted specimen this is filled with air and shows very clearly, also very numerons minute tubes opening into it. The opening-is on the-ventrat fice of the joint, under the base of the third joint, which is flexed upon the second. In the specimen mentioned $\Omega$ irregular mass, probably a secretion hardened by alcohol, lies in tho aperture.

\section{- Characters of thr: Famuy.}

As nolhing purporting to be a complete description of the present family has ever appeared in English, we offer the following attempt at supplying the deficiency, although future study will probably necessitate amendments.

\section{Family Crasprosonmatidis Gray.}

Tolld's Cycl. III., p. 5.16 (1842).

Chordcunidx, C. I. Koch, such many recent anthors.

Iysiopetalida (pro parte majore) of Cupe, Ryder and l'ackard.

Body moderately elongate or slemler, depressed, convex or cylimiric, subfusiform, capable of being spirally coiled.

Head larger and broader than the first segmont, which fits into a concavity of the head instend of coveriug the hind portion of it as in Iulidic.

Eycs usually well-derelojed, of numerous (10-30) ocelli armanged in definite patches; entirely wanting in certain cave forms. 
Antennx remote at base, generally elongate, third and fifth joints longest, eighth joint with four olfnctory cones.

Mandibles with 8-12 pectinate lanelic, a molar tooth, is dentate lamella, and a masticatory plate. The stipe has a distinct curdo; exposed surface of stipe (buccal area) very large and prominent, convex, not areate.

Gnnthochilarium with stipes separate, carlo small; in front the two coniferons processes common to Chilognaths.

Mentun entirc, trapeziform, large.

Promentum evident, triangular, included between the kases of the lingual Jamina, or nearly ohsolete.

Singual lamina mother long, distinet, anterionly with or withont a denticulate lobe, pusteriorly separaterl by the promentum.

- Median lobe well-developed, with a longer or shorter usually tridentate process on each sicle.

First segment slightly longer, but otherwise smaller than the second.

Segments laterally strongly, moderntely or not all cariunte; the dorsal face of mel provided with six bristles, sometines rudimentary and very minute, more or less armnged in a transverse row; each bristle usually located upon a smąller or larger tubercle; surface otherwise smooth or roughened with tubercles not setigerous.

- -liepugnatoriat porcs Whinting.

Peligerous laminie all tree; plenra completely corlesced with scuts.

First, second, fourth and antepenultimate segments each bearing one pair of legs, the thirl and last two foutless.

Anal segment obtuse or broadly truncate, with two pupille at apex, each ending in a long, slenter bristle.

I. ga sevcu-jointed, generally long, the thirl, fourth aml last joints longest.

In males any of the legs of the first eight segments are subject to more or lesg molification.

Genital opening of males in the coxie of the second pair of legs, as in Polydesmidic.

Sumber of segments, 26,28 , or 30 , in adults; in young $28,20,: 23,19,15$, 19 younger stages unknown.

Distribution: Europe. North America, Northern $A$ sia and Northern Africa.

The scarcity of individuals of this family, the small size of the animals, and the fact that few localities outside of Europe and Sorth America have been thoroughly searched, lenve it entirely probable that the above distribution will be extended to the momntain regions of Central and South America and Asia. One species is known from the mountains of Mexico. It is a significaut fact that not a single form has been reported from the tropical regions, and the writers are confidant, after repenterl and care- 
ful searches, that the family is not represented in Liberia and the neighluoring European colonies of the west const of Africa.*

The above is substantially the sane characterization of this family as that given by Latzel, with a few deviations, two of which are noteworthy. The first is that we credit all Craspedosomatidie with six bristles to a segment, and the other that we give the number of segments as sometimes $2 \mathfrak{h}$ and 28 , chnnges which we will later on attempt to justify. 'The following additional description will npply to all the American species known to us and included in this paper. It has been oir intention to omit from it no character common to all the species, no matter how unimportant any might seem to be, and for the sake of brevity, charncters given here will not be repented in generic and specific descriptions.

We consider it probable that most of the statements will be found true, except where noted, for all Craspedosomatidie, but as many of them have to former writers seemed too mimportant to be included-in-family deseriptions, and-others liave not been previously recoried at all, it seemed the part of cantion not to combine them with the preceding description male to accommolate the European forms, and moditied only enough to admit the $\Lambda$ merican.

Body moderately elongate, about ten times as long as its greatest trangverse diameter; posteriorly laterally compressed (except Branneria), giving an oval cross-section with dorso-yentral diameter greatest.

Vertex smooth, prominent, broally and sub-angulately emarginate pusteriorly, sparsely hirsute with hairs of moderate length; a short; fine, unclian sulcus and suture on the posterior portion ending at the point of grentest elevation.

Clypeus not distinct from the vertex by an apparent snture, + rather flat; lower part more hirsute, and with an elevated trausverse ridge just above the labrum.

Inbrum anther long, somewhat clecurvel, ns lenst as broad as the lower part of the clypeus; corners l,roally rounded, the emnrgination rather slallow. There are two transverse rows of setigerous punctations as is usual in Iulidac, the upper row containing four and the lower ten punctations. The lateral bristles of the upper row are farther from the median than the latter are from each other; lower row interrupted behind the emargination.

* After the alove was written Mrr. Poeock published his new genus Heterochorleumn from the mountuins of Burmah, and we became acquainted with the description of a New Z/ailand species of the fanily, Craspedosoma trisefosmm Hatton (Ann. \& Jag. Nat. Hist. Ser. 4, Vol. xx., p. 116, Aug. 188\%.

$\dagger$ Differing in this from most Inlidic and Polydesmiclie. 
Antenne filiform or sub-clarate, moderately pilose, the hairs increasing in length and number on the distnl joints. Seventh joint of antenna with a conic-nannillate sense-organ tipped with a long fine hair. Mandibulary stipe with the exposed surface smooth, more or less hirsute with short hairs.

Hypostoma apparently not a part of the gnathochilarium, in the sense of haviur any intimate connection with that structure. In all the species examinel it apjears as a chitinized ridge around the ventral side of the slender neck of the animal.*

The stipes of the gnathochilarium are proluced posteriorly far beyond the menturn and embrace the sides of the neck, which lies in the sinus thus formed behind (nbove) the mentum.

First seginent semi-cireular to broally reniform in front; nearly straight behind, except for a broad, shallow enargination in the middle; anterior margin and haterul angles with a fine raised edge; three seta on each side; surface smooth.

Subseruent segments with three setse on ench side, one close to the posterior angle of the lateml carina, the second slightly farther from the anterior angle, the third shout midway from the carina to the median line. On posterior scyments the armagement tends toward a stiajglit transverse line, and the setax are longer than on anterior segments. Beginning at the midulle of the first segment and ending on the penultimnte segment is a fine longitudinal sulcus, or rather a pair of sulci with a very fine raised line between (not apparent in Bianneria). The surface of the segments, when not otherwise roughenel, is fincly reticulate, the pattern of the reticulation varying on different species and different parts of the body. When carind and tubercles are present the exo-skeleton is scarcely thickened, the body cavity extending out into all prominences.

Supplementary margin not evident.

Anal segment without merlian furrow, trumente behind or with a bronl shallow emargination; broally sinuate on the sides. On this segment there are eight setigerous tubercles, two lnated near the niddle of the lorsal surface of the segment, the other six near the posterior margin, one on each side by the sinuation, one at each corner of the enargination, and two near the median line, these last with thickened, conic or papilliform lases.

A nal walres tot strongly convex, more prominent above the middle, each with three setse close to the margin.

Prenual seale scmi-clliptical, bronder than long, broadly truncate posteriorly, with two long lristles directed backwartl.

Peligerous lamine inedianly produced into a conic process which lies between the approximatel coxic, and has its anterior face exposed. This cx-

* Judging from the present family it would not be an antecedently improbahle theory to regard the hyjextoma as the ventral part of the first segment. In that case it would not be necessiry to consider the third segment footless, but to suppose that the ventml plates of the second and thirl segments have been crowded somewhat ahead. This also accorls with the opinion of Heatheote, the result of a study of the cmloryology of Iulus. 
posed face may be smooth or roughened, plane or with a longitudinal carina. On the 12th legs of males of some species the apex projects antero-ventrally as a large conic process.

First two pairs of legs 6-jointed, the others 7-jointel, by the intercalation of a very short joint just beyond the coxa.

As the species here described have usually been placed under the Lysiopetalida by American students of this group, it may not be superfluons to notice a few considerations regarling the systematic importance of the charneters on which this family is based.

The Family-Chordemidre was erected in 1847 by C. L. Koch, his entire characterization being: "Der Körper standhaft mil 30 lingen," and this would be suflicient, as far as known, to distinguish the Europenn species among Chilognatha. Mature indivicluals of certain small species of Iulida sometimes occur with as low as 30 segments, but in no Iulus is the number of segments constant. We have, however, in $\Lambda$ merica at least four species of Craspedosomatide with less than 30 segments in the mature condition, a fact which might scem to militate against the validity of the fnmily.

The number of segments, howevei; though appenring to be a claracter of considerable value on account of its supposed constancy, is by no means the most important of the numerous differences between this and other families. The more important distinctions have been neglected entirely or passed with a mere mention because of the easy statement of which the above apparently sufficient character was capable. In many respects the Chordeumidx are evidently the highest of the helminthomorphous Diplopoda, if not of the whole group.

In the first place, the hend is proportionally much larger than in nny other diplopod family. Instend of being enclosed or covered by the first segment, this last structure forms a sort of neck, fitting into the posterior concavity of the head, and allowing a much freer motion for that member thin is possible for other Diplopoda. All the organs connected with the head are in a comparatively high state of levelopment. The eyes, antenuie and mandibles are all capable of more effective service than the corresponding structures of other families.

The legs are proportionally longer and the animals capable of faster locomotion. 'This fact is correlated with the absence of re- 
pugnatorial pores as a menns of defense. There is no reason for supposing that the meabers of this fnmily have or ever had any thing like repugnatoral pores, notwithstanding such statements as "Annuli with two pores on ench side of the median line.Pseudotremia,"* and the charncterization found in some of the more careful Europenn works "Repugnntorial pores obsolete," or " repugnatorial pores evinescent." In the one case the the sockets of the Iateral seta have been taken for pores, while in the othel there has been an unwillingness to say "pores wanting," on account of their constant presence in other families.

The six setigerous tubercles of ench segment are perhaps the most distinctive fanily character. In some species the setre or tubercles or both are microscopic and rudimentary, but this only shows the tenacity of the character, as in no other recent family are there similar bristles.

In common with-the-Lysiopetalick-the-pedigerous tamina are all tistinct from the otherwise complete segmental rings.

It seems to us that the combination of these lnst three characters, want of repugnntorinl pores, six setx or spines, and the free pedil lnmina is sufficient ground for the opinion that the Craspedosomatida have of all living Diplopoda the greatest resemblance to the carboniferous gromp A rchipolypoda.

That the relationship is very close we do not contend, but merely that the similarities are greater than in other recent forms and are not merely apparent but real.

The spines of existing Chordeumida are insignificant in size when compared. with those of some of the fossil genera, such as Acantherpestes, but are the same in number, arrangenent and method of attachment to the segments, $i . e$, they stand in socketlike. bases. Moreover there were other carboniferous forms which had bristles proportionally not much, if any, larger than those of Trichopetalum and Scoterpes, and of the same slape.

Other minor characters reinforce the nbove view, such as the large size of the hend, prominent eyes, fusiform, somewhat flattened body and long legs.

That Chordeumidse were probably more abundant in former geologic periods is seen from the fact that a consilerable number

* Dr. Cope informel me recently that this statement was the result of accident by which the words "Spirnstrephon" and "Pseudotrenia" were substituted for mach other. [O, F. C.] 
of species have been described from the Baltic amber. They are at present probably among the least numerous as far as individunls of each species are concerned. North America is perhaps to be looked upon as the headquarters of the family, on account of the comparatively large number of generic types, though the number of nerr forms yet to be discovered in Europe is probably very great.

If the Craspedosomaticla are the highest, in certain senses at least, and at once the most primitive of recent Diplopoda, it follows that the other families are to be looked upon as comparatively degraded, even if more complex, as in the aldition of the repugnatorial apparatus.

\section{Generic Classification.}

The-more-recent European_writers_have-seemed inclined_to -in _-.. clude all the previously described American gener, except Pseudotremin, under the Furopenn genern Craspedosoma and Chordenma. Pseudotremia was kept distinct mainly on account of the misapprehension that it had no dorsal setr. From deference to the usually more thorough methods of the Europen investigators we began our study with somewhat of an expectation of the probable correctness of their view, which we still think was more or less justified by the incompleteness of American descriptions. We were soon convinced, however, that among the American forms are natural and compact groups of species meriting generic recognition. Between the species of such groups the characters of the antenne, eyes, body-segments, gnathochilarium, legs and genitalia agree in indicnting close affinities. Especially valuable, by renson of their constancy and ense of expression, are the characters of the ninth* legs of the males, and differences in these have always been reinforeed by those drawn from other parts of the body. That these secondary sexmal charncters have not had their importance generally recognized in classification is no reason why they should not now be made nvailable, and

\footnotetext{
* These have been referred to hy Packard and others as the eighth legs, while Latzel considers them a part of the genitalia and loes not count them. We believe it will be found more contionient to think of the eighth legs as replaced by the genitalia, and thus keep the numbers of legs and segnents uniform in the sexes.
} 
we helieve they are worthy of being put forward as the most satisfactory yet suggestecl.

\section{Synopsis of Genera.}

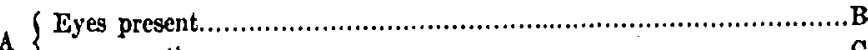

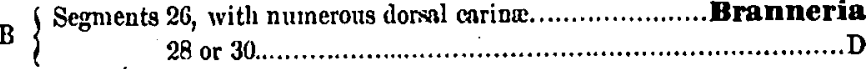

C Sixth male legs crassate, the ninth unarmed..................Zy Eonopus

C \{ normal, claw of niuth large.....................Scoterpes

D $\{$ Ninth male 'legs 2-jointeh, withont claw.....................................

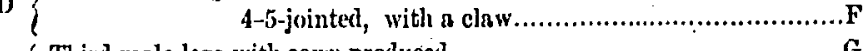

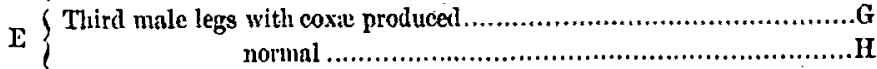

$\left\{\begin{array}{c}\text { Ninth male legs embracing a bifid plate; dorsum granular. ; } \\ \text { Pseudotremia }\end{array}\right.$ I

without plate; not granular...............................

\{ Secomh male legs-strongly erassate; seventhlegs norninj. Under wootia

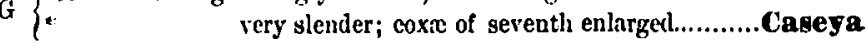

H Last joint of male legs hispid; segments $30 . \ldots . \ldots \ldots \ldots . . . \ldots . . .$. Conotyla

H $\{$ not lispid; segments $28 . . . . .$. Trichopetalum

I S Ninth male lergs distally clavate; second joint slenter ........ Bactropus

\{ hamate; seconl joint robust.................Cleidogona

'The presence or absence of eyes may not, of itself, be a sufficient generic character, as Latzel has said, though it certainly shows considerable divergence. In the preceding table this character is used merely as a convenient means of separation; the other features we believe to be of diagnostic value.

The external differences between the genern are not inconsiderable and it is possible to separate them without dissection. To facilitate this we add a key in which mere external chnracters are employed. That new forms will soon be discovered which will interfere with the continued utility of these keys, we can but expect.

Artificial Key to Genera.

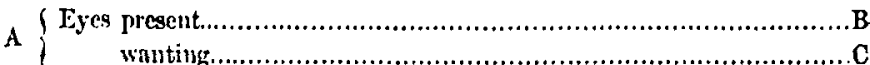

B Jorsum rough with mumerous (arinae or grunules....................... D

smonth, except the six sctigerous tubercles......................E

C Sixth male legs crassate; the ninth unarmed ..................Zygonopus

C nomal, elaw of ninth large.................................Scoterpes

D f length $6 \mathrm{~mm}$.; segments 26 ; dorsum carinate................ Brammeria

f $18-30 \mathrm{~mm}$.; segments 30 ; granulate.............. Pseudotremia 


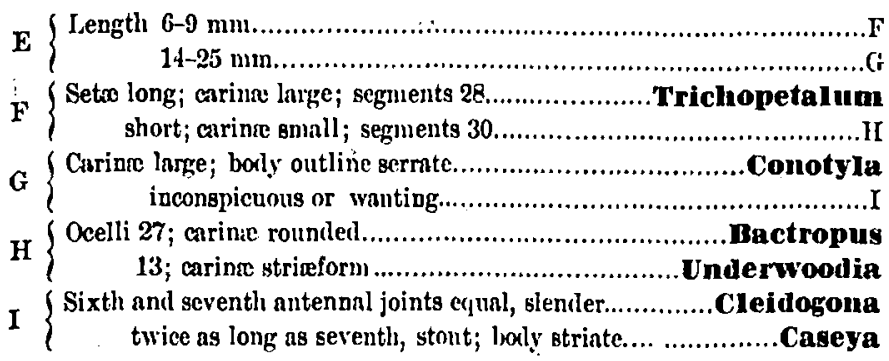

To judge from the works of Latzel, Haase and Verhoeft, there are also among the European Craspedosomntidie groups of species. agreeing in secondary sexual characters, but. there secms to have been no attempt at an arrangement based on homologies of this sort. We notice after the descriptions of the American forms the more striking of this class of chuncters-as-exhibited in the European genera and species, the generic descriptions being arranged on lines parallel with those previously given.

Dr. John A. Ryder was the first to use such characters as a bnsis of generic distinction. In describing /yggonopus he calls attention to the recognized importance of sexual characters in the generic classification of other groups, notably Crustacen, and affirms their avilability in the Myriapoda.

In the Polydesmida the ninth male legs are unmodified, while in Craspedosomatida we have a series of gradations from the fivejointed down to a nearly or quite complete transformation into complex genital apparntus. In A merica are found the first members of the series, from five-jointerl to two-jointed, while the others are found in Furope. It may be that in the European forms these legs have so completely taken on the function of genitalin as to be more susceptible of specific modification and are not of so much value in generic distinction; in the American forms, at least, they seem worthy of all the weight given to rudimentary and secondary sexual characters. Among the species already known the form of the ninth male legs is so constant an index of a whole complex of characters of other kinds that it is possible to distinguish the genera by them alone, as in the following table:-
$\Lambda$
$\left\{\begin{array}{r}\text { Ninth inale legs } 4 \text { - or } 5 \text {-jointe } \\ 2 \text {-jointed.......... }\end{array}\right.$
B \{
...B
$\{$ First and second joints thick, snbequal in size very large, the second cylindrical, slender. 
Second joint rounded oval, busal joint flask-shitpetl............................ much longer than wide, the first not attenate................... \{ Third and fourth joints suleequal, uarrow. Pseudotremia much longer than fourth, thicker than second..............Bactropus

E First joint gradually attenuate distal......................Underwoodia

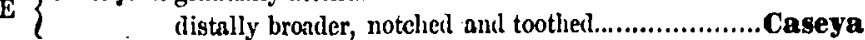
F Second joint with a small chitinous knob, genitalia simple..................G smooth; the first attrchel to prosterior genitslia....Conotyla G S Second joint clavate; eyes present; serments 28 ........Trichopetalum G $\left\{\begin{array}{r}\text { obclavate; eyes wanting; segments } 30 . . . . . . . . . .2 \text { ygonopus } \\ \text {. }\end{array}\right.$

It should be remembered, lowever, that these genera rest on other charncters, and that for the present, at least, the ninth legs are not a necessity to the generic classification here adopted.

A merican species of this family have been referred to the following genera not here recognized as valid or as properly ap- .- plied._. It mny be warth while to notice briefly the different rensons for such treatment.

Spirostrephon, Brandt (1840) was erected to contain Lysiopelalum lactarium (Say), then looked upon as one of the Iulidx. To use the name for species distinct from lactarium by differences of family importance was entirely unjustifiable.

Campodes of C. L. Koch (1817), was referred to this family by its author, and was not heard from afterward until Mr. Bollman identified Cryptolrichus cesioannulatus (Wood) Packard with it. It was clear to us on reading Koch's description with specimens of cxsioannulalus in hand that the description could not possibly apply to that species, and the idea suggested itself that Koch's description portrayed an animal astonishingly similar to Iulus virgatus Woorl. On comparing specimens of that species we found the agreement with the description to be complete, down to the smallest detril mentioned. Both the varieties of coloration which Koch described as species are also common, so that the two can be united. Koch's specific name (1847) antedates that of Wood (186t), and the species must stand as Iulus favicornis (Koch). The genus Campodes never had any reason for its existence, and can be dismissed from the subject. It might be well to acld that we have found sexually mature I. flavicornis with 30 segments. This species' seems to be very nearly allied to the European I. pusillus Leach, described long before the time of Koch, but with which he did appear to be familiar.

Craspedosoma of Lench and Rawlins (1814), is the oldest genus of the family and contains a considerable number of European spe- 


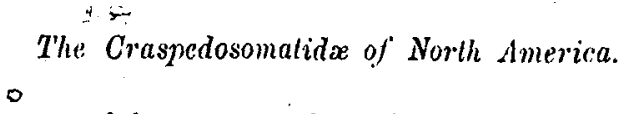

cies, but none of these seem to have the second pair of feet of the seventh 'segment with more than one joint, a club-shaped, perpendicular'structure, thus differing distinctly from the more closely allied of the American genern: Conotyln, Trichopetalum, Scoterpes and Zygonöpus.

Chordeuma, C. L. Koch. Latzel suggested tho possibility that Trichopetalum juloides Harger would be placed here. Charaters drawn from the genitalin, gnathochilarium and secondary sexual characters give ample reason for holding the American form distinct and erecting a new genns for its reception.

Striarin has been recognized as the type of a distinct fumily.

Cryptotrichus Packard, is replaced by Cleidogona.

In Austro-Hungary are found two genera of Craspedosonatida with broad lateral carina, Atractostoma closely resembling the Polydesmidx, and Rhiscosoma the Polyzonidie. Latzel failed to find bristles on an immature specimen of Rhiscosoma, but as "other individuals referred to the same species lind bristles we have not lost confidence that the bristles are iniversal in Chordeumidie, more especially since finding them on Psendotremis where Latzel asserterl their non-existence.

Humbert and Sanssure * proposed to include all the species of this family as here constituted under Craspedosoma, divided into two subgenern, Craspedosoma, in a stricter sense, and Chordeuma, alleging that in Craspedosoma there is a promentum distinct from the mentum, while in Chordeuna the mentum is entire, and rounderl anteriorly. Iatzel takes no notice of this distinction, and does not describe or figure the gnathochilarium of the only species, Chordeuma sylvestre Koch, leaving the implication, however, that there is no important difference in this respect, since the family description states that the promentum is "dentlich entwickelt, dreieckig."

Meinert anited Craspedosoma with Polydesmus, but his reasons for so doing do not seem to include a knowlerge of the more fundamental relationship, and were matters of generic descriptions based on external characters.

Dissection is an absolute necessity in studying the genitalia of the smaller forms, and the greatest caution inust be exercised, for the different views of the same irreguiarly shaped genitalium will look like entirely different structures. The small size of the

* Etudes sur les Myriapoles, p. ij9. 
members of this family makes the study and preservation of the dissected parts difficult unless they are mounted on microscopic shdes. This method has the further advantage of allowing corresponding parts to be viewed at the same angle, so that fictitious differences are not multiplied. Some genitalia are, however, so irregular in slane as to make it diflicult to determine a species from one drawing alone. Descriptions of genitalia are nearly worthless without diagrams to aid in their interpretation.

In describing the antenna we linve adopted the form of a continned ratio for showing the comparative lengths of the joints. The third joint, the longest, is taken as the standard, and given the value 10, thus the ratio of ench joint to any other can be rendily seen.

We have not attempted to describe the immature stages of the species, since the material wns nol collected with n view to such study._Young individurls of this family are less commonly found than in the others, and are usually so delicate as to need special care in preservation. Such observations as we have been able to nake have been entirely in the line of those of Latzel.

In the direction of describing forms and varieties we have done equally little. This is partly due to the fact that our material has been neither fresi nor very extensive, so that variations of color and external claracters bave not been seen to advantage. It is also dne in part to the fact that we consider that in Diplopoda, as in Arnclinida and Crustacen a different plan of male genitalia is to be looked upon as of specific importance. There is not in the habits and habitats of the Diplopoda apparent reason for the multiplication of external differences, but the differences

$--\quad$ of genitalia and secondary sexual characters are not therefore less important when they occur, but inther more so. Until we have a recognized criterion of what a species is, the matter of specific classification must remain largely a question of convenience. The characters of the genitalia indubitably have important bearing on the question of specific distinctness. The ultimate value of every difference, as a menns of specific definition must of necessity be settled by ascertrining the constancy of the particular charncter in the forms to be separated. As a practical method we lanve proceeded on the assumption that species with evident and rendily assignable differences in the genitalia should be considered distinct until the differences are shown not to be constant. 
HRANNERIA Bollman, 1893.

Bulletin No. 46, U. S. Nat. Yusenm, p. 158.

Lyes of numerous (16) ocelli arranged in triangulur patches.

Antennax of moderate length, subclarate.

Segnents depressel, with prominent latemal carine; dorsally with numerous longitudinal corinic.

Male geuitalin complex.

Segments of adult 26 .

We have seen four specimens of this genus, one being a mature male, but clissection was not attempted, owing to searcity of material and small size.

This genus does not appear to be closely related to any other, the sculpture of the dorsal surface being unique in the present fnmily, as is nlso the small number of segments. This last peen. linrity is the more interesting from the fact that European writers lave insisted that the number of segments in this family is always 30 , refusing to believe the statements of American writers to the effect that a less number occurs.

The mature male is in the collection of the University of Indiaina, and we diel not have opportunity of making drawings or $n$ description of the genitalin. We were, lowever, nble to assure ourselves that their complexity equals or exceeds that of any other species known to us.

Bramueria carinata (Bollm.).

Craspedomoma carinatum Bollman: Ann. X. Y. Acad. IV., 109 (1888); Bulletin 40, U. S. Nat. Suscum, p. 83; 1 is.

Eyes triangular, ocelli 16, withont regular armungement.

Antenne large in proportion to the size of the animal, sulsclavate, the two distni joints being ejual in length, while the fifth and fourth are subequnl, ench about twice the length of the seventh. Sixth joint thickest, $.14 \mathrm{~mm}$. in diameter.

First segment semicircular, anteriorly rugulose and with irregular depressions; along the posterior chage n row of longitulinal rilges; in front of these are several similar rilges not arranged in a regular transverse series, and not placel with regularity in front of those of the posterior row. $A$ setigerous tubercle situated at the posterior angle; another ahout midway between the anterior and posterior margins, a little closer to the median line than to the lateral corner; a third tube:cle nidway between the other two. Setro.1 mm. long, slender, topering.

Subseruent segments with the anterior subsegment covered with short,

ANwats N. Y. ACAD. SCr., IX, Oct, 1895.-3 
rather irregulur, longitudinal, subreticulate ridges; yosterior portion anteriorly slightly rugulose, also finely reticulnte, the reticulation extending over the entire postetior portion of the segment; on the posterior margin is a row of ridges similar to those of the first segment. Cephalaul of these are also irregular rithes which are sometimes in a somewhat definite series and ocasionally joined to those of the posterior row. Internl carina well cleveloped, the carine and Interal surface evidently reticulate. Tho three tubercles are situnted, one at the yosterior angle of the lateral carina, the second at the anterior origin of the carima, the third between the anterior and posterior sulbsegments and about midway between the median line and the lateral carina. On posterior segments the tubercles come to be arranged in a straight line, as is usual in the other species of the family. Dorsil line not evident.

Aual s'gument rugulose, posteriorly nearly straight, not produced to cover the anal valves. $A$ tabercle on ench side close to the median line, nenr the mirldie of the segment.

Anal valves inargined, rugulose.

Preanal scale, broally and deeply emarginate; on each side of the emargination is a long, posteriorly directed bristle.

Length 2 mni.; wiltlr. 4 nmm.; - 20 segments.

Color hors-brown, the feet paler and the antenne darker than the boly.

Habital: Benver Creek, Jefferson Co., Tenn., Prof. J. C. Branner; Little Rock, Ark., Mr. C. H. Bollman, U. S. Nat. Museum, No. 164.

The hend is proportionally snaller in this species than in the others known to us. The sinall size, fewer segments and polydesmoid clanracters seem to indicate a clepauperate form.

The pair of large terminal spines with prpillate bases were not present, but it is probable that they had been broken off. The small size of the animal makes it impossible to distinguish their sockets.

By "Interal plates distinct" Mr. Bollmnn probably intended to imply that the lateral carina are evident. There is nothing suggestive of the distinct pleure of the Glomeridie.

PSECDOTREMIA Cope, $186 \%$.

Journ, Am. Philas. Soc, XI, p. 179.

Tyes moderntely developed, of namerous (13-27) ocelli arranged in irregu lar pitclies.

Antenne very long and slenter, third joint longest.

Manulibles with 12 pectinate lamellic.

Promentum present, triangular.

Segunents with swollen, shoulder-like carine, the laternl surface longitudinally striate, the dorsal uneven with rounded tubercles; setax short; clavate. 
First two pairs of legs of male short and slender, the next five pairs longer and much crassate.

Anterior male legs hispicl on the interior face of the last joint.

Ninth pair of legs of male four-jointed and clawed, the bisal joint large and thick, inferiorly decply sinuate; second joint slender, cylindricnl; distal joints short, the apical conic. The basal joints enbmce a bifid lamina (sec fig. 6).

Tenth and eleventh legs of malc with large coxal apertures; the coxa of the eleventh legs with a conical process at base.

Pedigerous laminne with a vertical carinn. Segments of ndult 30 .

The two known species of this genus inhabit caves, and have been collected in Virginia, Kentucky and Indiana. They are not, howerer, to be looked upon as enve animals in the strictest sense of the word, as they are provided with eyes. The eyes are less numerous and less prominent thin in the other large species, and seem sometimes not to be fully pigmented. That the number has been reluced by cave life is an unsafe inference. The Polyclesmidie have noeyes and yet very few-anceave species.

The legs and antenna are proportionally the longest of any Diplopoda known to us. That this is due to cave life camnot be maintained, for such thoroughly carernicolous species as St:olerpes copei and Zygonopus whitei do not lave longer antennx than some of the open-air forms.

The proximnl three or four pectinate lamella of P. caicernarun have the apices of the spines bifid. We have not marle sufficiently numerous dissections to be conficlent that this is a constant character, but its occurrence is certainly wortly of note, for such a condition does not seem to have been recorded.

The sculpture of the dorsal surface is also characteristic, none of the subsequent genern being roughened except by very fine areolation, excepting also, of course, the six setigerous tubercles. The carine also are somewhat squarer and higher up, making the dorsal surface flatter than in other American genera, although the body as a whole is not depressed.

In a description of this genus, purporting to be clrawn from specimens sent by Dr. A. S. Packarl, Jr., Latzel * says: "Dic 6 Borsten und die zugehorigen Wälzchen fehlen ganz." The bristles must have been rubbed off in sending, as is usually the case, though some of the bristles of the posterior seginents can nearly always be found.

* Myr. d. Öst.-Ung. MIon. Bai. If. pr. 6.4 and 21 t. 


\section{Pseudotrentia caveruarum Cope.}

Pycudutrmia caternarum Cope : Joutu. Am. Philos. Soc., XI, pp. 179 (1869); Trans. Am. Ent. Soc., May, 1870, p. (j7.

Spirostrephon cavernarum Cope : Am. Nat. VI, 1872, pl) 409.

P. corernurum Copc, liyder : l'roc. U. S. Nat. Mus. III, 1881, pp. 526; MeNeill, Bull. No. 3, Brookville Soc. pl. 8 (1888); Bollman, Ibid. XI, 1888 , pli. 405; Bulletin 46, U. S. N. M., lp. 106.

Body somewhat fusiform, brondest anteriorly at abont the fifth or sixtl segnent, narrowed aloruptly cephalal, and gradually coudad to the last two or three segments, which are narrowed very absuntly. Carince molerate, situated above the midlle line of side.

Clypeus near the middle with two well-pronounced depressions about the size of the antemual sockets; lsclow are two smaller depressions sulsconfluent with the others.

Eyes morc or less triangular in form, sometimes elongate or lumate, ocelli varying from 13 to 17, usually 15 or 16, without legularity of arrangement.

Antenna filiform, 4-4.5 mm. long, .18-.22 mm. thick, moxlerntcly pilose, approximate ratio of lengths of joints to each other, beginning with the seventh, $2: 3: 8: 6: 10: 4: 1$ :

Mentum subrectangular, twice as loroad as long, the anterior and lateral margins convex, the posterior concave.

Promentum witlout lairs, triangular, broaler than long (8:5), sides nearly strmight, posterior corners not resching the stipes.

Stipes with lase of inner process more than half the length of outer process; lateral elge of outer process with cones nearly to lanse.

Lingual lobes subecual to lingual lamine, with five sense-cones.

Middle lobe nearly square in front, twice as brond as long, subequal to. lingual laminx.

Styliform process deeply trilobed.

Fìrst segment anteriorly nearly semicircular, slightly concave behind, medianly broally cmarginate. Anterior margin elevated, as well as the posterior along the enuargination. Surface smooth; a fine furrow on ench sidu of a median ridge, begimning about the middle of the segment and extending to the posterior margin. On each side three setigerous tubercles, one situaterl near the longitudinal middle of the segrment near the median line, a second close to the laternl angle, the third on the posterior edge of the corner. The lateral bristles measure. $2 \mathrm{~mm}$. in length.

Subsecjucnt segments with the posterior subsegment coarsely tuberenlate on its lorsal portion; laterally and ventrally with about 12 longitudinal striations; the superior striation is tlie langest, being on the portion of the segment laterally most prominent, and is directed obliquely, the posterior end lower down. On the superior elye of the posterior end of the carina is a slight protuberance bearing a short, clavate bristle; on the anterior edge of the elevated portion of the posterior subsegment are two similar slight protuberances the outer of which bears a similar clavate bristle. On the anterior segments the surface of the melian portion of the posterior subsegments is smooth, the 
tubercles being confined to tle sides of the dorsal surface; tubercles become more numerous catdad to alout the twentieth segment, where they begin to le gralually obliterated, sil that the last few segments are nealy smootl. On the other hand, the bristle-bewing tubercles become larger and the bristles longer on the posterior segments. The tuhercles, especially the lateral, are conical or papiliform, and tipperl, especinlly the lateral and posterior ones, with a very short seta. Tlie circular, light-colored bases of the other clavnto or long setec distinguish them at once from ordinary tubercles. On posterior segments the six bristle-hearing protulferances become more and more arranged in a straight tiansverse row. The fine median rilge loceted in a shallow furrow is continued from the first segment to the penultimate.

In males the sixth and seventh segments are noticeably latger timn the others, being loth longer ami broader.

Amal segment with surface smooth, very slightly hirsute with short hairs. Posterior margin deflexed, syuarely notched in the midule, decply sinuate on the sides. On each angle of the emargination is a setigerous tubercle.

Anal valves margined, slightly rugniose, the vidges ruming oblinge to the anal opening, three setigerous tubereles at intervals, near the inner margins of the values.

Fint jair of lens of male six-jointer, the joints, berinning with the coxa, respectively, .20,.06, .50,..50,.16; aml .60 $\mathrm{mm}$. long; witlth of thirt joint .14 num. 'The joints are not specially morlifierl, nor roughened cxcept by' sparse hairs. Two small superior sccomlaly claws.

Scend legs of male also six-jointed, the joints, excepting coxa, measuring $.08 ; .50, .22, .16$, and .60 mu. long; third joint .16 mun. wide.

Third legs of male seren-jointed, as are all the others (except the ninth), joints measuring . $.30, .08, .10, .60, .26, .20$ and $.04 \mathrm{~mm}$. in length; wilth of first joint .40 inut. The serenth joint has the distal part of the inferior surface beset with fine bayonet-like proceses; as described for Couolyla fischeri. Two small superior secondary elaws.

Fourth legs of male with joints .3t, .0ti, .40 .60,.24, .20 and .60 mm. long; width of first joint .34 mm.; sesenth joint as oir third logs. Two superior sccondary claws.

Fiftir legs of mnle with joints .34, .06, .60 .74, .34, 20 and .ti6 mun. long; first joint . $34 \mathrm{~mm}$. widle; otherwise as for third legs.

Sixtl legrs of male with joints .40, .06, .3.t, .72, .30, .20, and .6.t mm. long; first joint . $.30 \mathrm{~mm}$. wille.

Seventh legs of male with joints.40, , .04, .56, . T.1, .30, .20 and .08 mm. long; width of first joint .30 $\mathrm{mm}$. Inferior surfice of coxit coveren with small rommled knols. Otherwise ats for thirel legrs.

Male genitulia (plate I, firg. 2 amd 3) very complex, consisting of four different structures:

1. An irregular, deeply bificl lanina (tig. 2) brond at hase, the lobes crossed by a very prominent, jounded, dingomal clcration, projecting mesad, beyond which they are nurowed to binentate apex, the teeth diverging, ono curved laternd, the other eamlac. A side view (fig. 3) shows that the mesal edge of the inner tonth is continuous with a broad subertical lanina, 
concave on the outsile. This whole structure is proliably articulated to a large basal joint whioh bears a few spines along its laterul margin.

2. An unpaired metian, slender curved spine, bifid at the tip, the teeth sharp-pointed, decurved and diverging. I'roximally the spine is thicker, somewhat compressed laterally, bronder dorso-ventrally, and yojects througl the fissure of the large lamina described above. Our clawing (fig. 2) might bo thought to indicate that this structure comes from one side, but this is not the case.

3. Caudad and laterud is on either side a slender, two-jointed, npically bificl, styliform structure, curved cephalo-ventral towarl tlye apex. But one of these is shown in our clrawing (tign. 3 , to the right).

4. Between the enlarged hasal joints of the ninth pair of legs is a sublylane deeply bifid lamina, the lohes of which are more or less deeply bitid with divaricate sublivisions. Our dmwing (plate $I, \cdot$ fig. 6 ) is from a specimen in which the inner elye of the primary lobe is merely enarginnte.

Ninth legs of male 4-jointed, the lassil joint subequal in length to the others taken togetler, and of twice the diameter; on the mesul face this joint. is derply excavite near the hise and agrin slightly above the middle, the sinuses separated by a large roundel knob, benring on its upper side a conical chitinizcl tubercle. Sccond joint slender, cylindrical, much longer than two distal joints taken together, sōinetimes twice-ns long.-.Third joint alout as long as brond; apienl joint somewhat conic, exceeling the third in Iength. Claw sometimes large and distinetly hooked, at others reduced to a shapeless chitinous tubercle.

Tenth legs of male with joints .34, .06, .54, .74, .26, .20 and .80 $\mathrm{mm}$, long.

Distal inferior surface of coxa with a large slightly elevated cushion of small, rounded knows. Thirl joint with the inferioc surface sparsely corered with rounded knobs somewhat larger than those of the coxa. Fourth joint proximally with a few knobs similar to those of the thirl joint. Seventh joint and secondary claws, as given for third legry. The secondary claws of this gpecies are situated farther distad on main claw than those deseribed in tho species of other grencin.

Elcrentl leg with joints .46, .08, .56, .70, .26, .18 and .78 mm, in length; width of first joint $.30 \mathrm{~mm}$. The first joint with a cone $.12 \mathrm{~mm}$. long and .08 nm. wille about the micldle of the inferior surface; just clistal of this a convex area covered with smull, rounded knobs, as is also the inferior surface of the thirrl joint. Serenth joint as in the preceling. Two superior secondary claws.

Color, according to Cope, varying from nearly white to a pale red, We have scen only alcoholic specinuens and these vary from a dirty white to palc horllarolor.

I.engtlı of mature specimens $18 \mathrm{~mm}$; widith $1.5 \mathrm{nmm}$.

Habital: Sonthern Virginia, first collecterl by I)r. E. D. Cope in Erlart's Cave, Montgomery Co., and in Spruce Rum and Big Stony Creck Cares, Giles Co.; Temnessee, Lost Creek Care, Granger Co., also Nickajack Cave (1)r. Cope); Indiana, Wyan- 
dotte Cave, Bradford and Marengo Caves, Craẃford Co. (Drs. Cope and Packarl and Mr. Bollman).

We have examined about seventy specimens from Wyandotte and Marengo Caves. The proportions of the sexes are about equal. U. S. Nat. II suseum, Nos. $87,420,421$ and 438.

Dr. Cope remarks: "This animal inhabits the ileepest recesses of the numerous caves which abound in Southern Virginin, as far as human steps c:u penetrate. I have not seen it near their mouths, though its eyes are not undereloped, or smaller thun those of many living in the forests, Judging from its remains, which one finds under stones, it is an abundant species, though rarely seen by the dim light of a candle even after consiclerable search. Five specimens only were proçured from about a dozen cnves."

In Indiana, on the contrary, Dr. Packard foum specimens in a small grotto, and that these were paler and had more rudimentary eyes than those collected in the Senate Chamber of Great Wyandotte Cave, three miles from daylight.

Accorting-to-Pr-Packint - the eyes of this species lave no neural connection with the brain, or rather, he failed to find an optic nerve after cutting over 400 sections. 'l'he origin of the specimens sectioned is not stated, and the conditions may differ in the species, as does the development of the cyes. Dr. Packird considered $l$. carterensis to be a variety of the present species, but we are unwilling to believe that its well-developed eyes are functionless.

As miglit be expected in a species limited in habitat, but with an extensive range there seens to be a large amount of variation in nearly all the characters, even those of the genitalia. It will not be surprising if a further study shows that some of these forms are sufliciently differentiated to merit specific recognition. While our material was aloundant it was all alcoholic, and the structure of these animals is so fragile that a thorough examination can scarcely be made without the destruction of the specimen.

The median process scpitrates it from the other $A$ merican genera, and indeed from all others. The genitalia of Craspedosoma raulinsi, lowerel, have two similarly placed slenter processes suggestive of homology.

*The Cave lauma of Sorthi Ameriea, p. 113. 
Pseudotremia carterensis Bollman, 1888.

F. curmomam var. carlerensid Packard: Proc. Am. Philus. Soc. XXI., p. 188 (1883). .

P. carlerensis Bollman: Proc. C. S. Nat. Museum XI., 1888, p. 405; Bulletin 46 L: S. Nat. Iruseum, [3. 107.

l:yes of 17-25 ocelli, groupred in triangular natches, but usually not in regular rows.

Posterior sulosegments dorsaliy denscly and erenly tuberculate with rounded elevations of somewhat equal size.

Male genitalis (plate $I_{3}$ figs. 9,10 ) consisting of three structures:

1. $\Lambda$ thin sulsplane lamina, with subparallel gides, one of which turns distally at a slarp angle and is proluced into a tapering though blunt-pointed process. The other margin is brondly sinuate, the distal half fimbriate with fine short hairs, the apical corner cut into longer lacince.

2. A thin lnmina apically curved upon itself and tapering to a point. . A duct can be traced from the lase to the aprex.

3. A bifil subplane lamina, lying between the bises of the ninth pair of lers, similar to that described for 1 '. cavirnarmm.

Color ahove dark horn-brown, soinetimes variously mottled with yellow on the the carine; helow, and laasl joints of lears yellowish in alcololic specimens, the apieal joints and antenna horn brown. Length $23-30 \mathrm{~mm}$. in mature individials; dimueter $2.5 \times 3 \mathrm{~mm}$.

Mabitut: "The Carter Caves, Kentucky, viz.: Bat Cave, $\mathrm{X}$ Cave and ' $Z$ wingler's Cave, besides a cave across the road from the hotel, which is used as an ice-house," (Dr. Prokard); Wyandotte Cnve (Mr. Bollman). We have seen four individuals from Wyanclotte Care (U. S. N. M. 436).

This species is the largest member of the family yet known from North America, and appears very distinct from $P$. cavernarum in its dark brown color and larger size. 1 careful examination, however, revenls the closest similarity in minor detnils, and we have not male our desciption cxtensive, for beyond the characters noticel above all the statements made for $P$. cavernarum seem to apply to this species. The eyes are more prominent and better pigmented, the segments more evenly tuberculate, the color darker, the size usually larger, and the genitalia entirely different. The antenne and the relative proportions of their joints are rariable in hoth species and we have been unable to observe any constant diflerence.

That the speeies, however, is ralid cannot be doubted. The male genitalia have but little similnrity of detail with those of P. covernarum. At the sane time the legrs of the ninth pair are 
practically undistinguishable from those of the former species, thus showing that variation in the genitalia proper does not affect these neighboring structures, making their use as generic characters desirable.

According to Dr. Packard this is "what may be called a 'twilight' species, living in small caves in situations partially lighted." In this connection it onght to be renembered that nearly all Diplopoda are nocturnal and lucifugous. It would not be a surprise to us if carefill collecting in the neighthorhood of the caves should reveal many of the so-called species in dark comers and crevices of rocks along with the open air species. There has been much more; careful collecting in the cares thim outsile.

\section{CheIDOCONA gen. nor.}

Cryplotrichus || lackarl, Pros. Am. l'hil. Sw. XXI, p. 180 (1883).

Spirostrephon Wool, not of Brandt; P'seutotremia C'ope pl).; C'ampodes Bollman, not of C. I. Koch.

Eyes well derclopel, of numcrous (2,i-29) prominent ocelli arlanged in triangular patches.

Antenna filiform, vely long and slender; third joint longest.

Manclibles with 12 jectinnte lamell:e.

Promentun present, triaungular.

Segments with lateral carina nearly olsolete; setigerous tubercles very sunall.

First two pairs of legs small aml siender; the noxt five paits in males moderately crassite.

Anterior male legs hispid on the interier lace of the last joint.

Genitalia of male of two priss of processes, the prosterior articulated with the anterior at lase.

Ninth legs of male ij-jointed and clawed; two hawal joints large, subeyual in length; threce distal joints suall, forming a book.

Tenth mul eleventh legs of male with larese coxal ajertures; coxa of eleventh leg with a conic proess, the third joint ummoditied.

Pedigerous lamina of tweltell lergs of male produced at apex into a large conic process directed cephalat.

Segments of adult 30 .

Distribution: Eastern States; reported from Mimnesota and Arkansas; thus far we lave been mable to find it in western Ontario, central New York, Isong Island, Connecticut and the enstern shore of Maryland.

'That the affinitics of Cleitlogroma are with P'seudotremia may be inferred from the numerons character's conmon to both genera. 
At the same time the differences are so great that to unite the genera as several aulhors have done seems unwarranted. In addition to the above dingnosis, the following description applies to the species noticel in this pape: :-

Body fusiform, brondest in the auterior portion, narcowed very abruptly cephaimi, very grauluuly caudal; in cross-section cireniar, slightly compresser? dorso-ventrally in front of the mindle, slightly compressed laterully cumbla. Carine very small, placed near the middic line of side.

Vertex prominent, nearly smooth, shining.

Clypeus sparsely hirsute with short and long huirs; a prominent trunsverse stipralabral ridge, ahove which are a few more or less evident fine transvence

.re wrinkles. $\Lambda$ long the latenal margins a deep, somewhat oblique furrow curving mesad below, above the transverse ridge.

Eyes in a triangular patch, armanged in several transverse rows; as in other gencia there is tritally one ocellus on the lateral margin above the upper row, with which it is usually comtel.

Antemuc moderutely hitsute, thic distal joints move hirsute than the basal. Approximate proportions of lengths of joints beginning with the seventh, 3: $3: 7: 5.5: 10: 5: 2$.

First segment, viewed from above, pointed reniform; surface smooth, excepting three very suall light-colored protuberances on each side; the lateral located at the cxtrenie corner of the superior buylace of the scenent; the second a short distance mesul and cephalarl from the fist; the third neares to the median line than to the second. The bristles mensure as much as . 15 mul. in length.

Subseruent segments with the lateral carine more pronouncel for six or seren scgnents, whenee they decrease in size. On the anterior segments the lateral bristle-hearing protuberance is close to the posterior margin; on succeeding seyments it is not so close, mitil the antepenultimate is reached. As the carine decrease the bristles of the lateral protubernnces incrense, posteriorly; they are directed horizontally and appreseed to the side of the borly. The middle pair of protuberances appronch the median line on pusterior seirments, and the six bristles are more and, more nearly armuged in a strnight transverse row. A line median rilge placel in a furrow runs from the first to the last segment.

Anal segment without median furrow or ridge; broally truncate or slightly emarginate prosteriorly anul deeply sinuate on the sides; with eiglit bristles, of which two are locited on the anterior portion, near the melian line; the others are directed more or less horizontally from the posterior margin. The median pair have thickench conical bases nearly as long as the slender bristles risingr from then. The other brintles are locaterl at the corners of the traneation and the upper part of the latemal sinuation. I'osterior margin very thick and slightly grooved postoriorly.

Anal valves slightly excecling the anal sccrment, not strongly convex, more prominent above the middle, and angulate, the margins scarcely raised; above on eaclı sicle with threc bristles at epual distauces from each other. 
Preanal seale semi-elliptical, bronder than long, broally trumente posteriorly; with two long slender bristles directed latchward from near the posterior margin, and appressed to the anal valves.

First two pairs of legs much smaller than the others; next tive pairs in male crassate. Iegs 10-12 longest, the leys dëcrensing both in length and thickness crudad, so that the last peirs are very slender.

Second leugs of male with a regular row of spines lordering the last joint on the vêntral edige.

Legs 3-7 not specially moxlitied, further than being crassate, and hispid on the ventral fuce of the last joint.

Inle genitalia of twro paiss of apprendnges, the posterior jointed at base to the anterior. The anterior pairs langer than the other and cursetl lackward, the posterior is more or less clavate or capitate.

Ninth legs of male $\overline{5}$-jointed, the two proximal joints sulvequial in size and length; the other three very small; the last joint somewhat longer than either of the two preceding. The shupe of the joints differs somewhat in the different species.

'Tenth lerr of male with a conic process on the rentral face somewhat leyond the midalle of the proximal joint.

Tenth anl eleventh legs of male with large npertures in the lassl portion of the coxe. Sometimes the ajertures have raisel rims which alter the ontline of the joint when viewerl from in front or behind, and sometimes a membrane or harlened secretion project from the aperture.

Color purplish horn-brown, usually dark, mottled and marbled with pinkish or dirty white.

\section{Cleidogona casioamunlata (Wool).}

Spirostrephon cersioumultetus Wool: Trans. Am. Philos. Soc. XIII, p. 194 (1865).

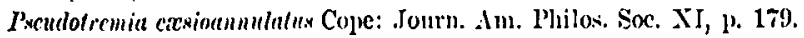

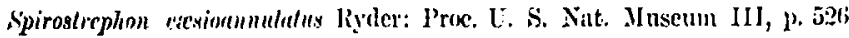
(1881).

Cryptotrichts crsiontmutettes (Woxt) Packart: P'roc. Am. Philes. Soc. XXI, p. $190(18 \times 3)$; McNcill, I'rne. I. S. Sat. X[useum X, p. 333 (1837); Bull. So. 3, Brookville sice. p. 8 (1:88).

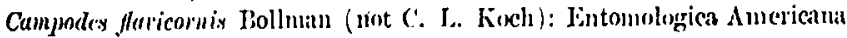

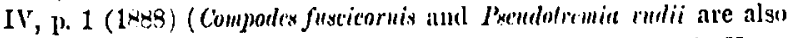
here placed as synonyms ly Bolluman) Amm. N. Y. Acatl. Sci. X, p.

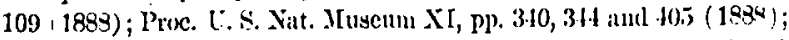

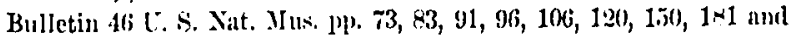
183.

Fyes more or less triangular in form, of about 25 scerlli, six of which lworler on the margin of the vertex, and if groupel in rows purallel to these apprar to be arranged $6: 5,2,4,3: 2 ;$ (sometimes) $1-2,2$ or 26 . If the rows are looked upon as transwerse the numbers are, beginming posteriorly, $1: 1 \div 2$ : $3 \div 4: 5: 5:-4=25$, or diagimally $1: 8: 6: 5 ;: 4: 3=25$. 
Anteunic filiform, $3 \mathrm{~mm}$, long, $16 \mathrm{~mm}$. thick.

Male genitalin (figs. 138, 139, 145-148, 150), with the anterior and larger arm bent abruptly coudad (or (lorsad). At apex it is more or less bifid, with the outer lobe longer, so that seen from below the end appears either nore or less trunate, or if the animal is tilted so as to look nore directly at the apical portion of the genitalia the appearance is that of figures 139 and 146. This last is somewhat of a side view as well. The longer lobe is at apex more or less fimbriate on the posterior side.

Posterior arm of genitalium clavate, the apex curved toward the anterior arm. The shape will be seen to vary consilerably in the three figures 138, 147, 150; from the explanation of plates it will be seen that the figures are from different localities, and further stuly may necessitnto another disposition of the different forms.

Ninth legs of male (figg. 144-145) with basal joint molcritelywarginate on the ventral side, near the basc; toward the apex, on the sime side, is a slarp tulsercle directed distal. Sccond joint nearly laalf as broad as long, the Heatest diameter at nlout two-thinds of its length, gralually jarrower below, more abruptily so above. Three distal joints small, togrether equal in length to alout lialf the second joint. Last joint nearly equal in length to the tivo preceling, constricted above the mirldle and obliquely crossed on the anterior side, just below the constriction, by an ohlique rilge the edge of which

- is sharpant spinose-traininte, giving the appenance of another joint. Two proximal joints with few lairs, the three distal incrensingly hirsute. Clnw nearly normal, one evident supplenentary claw.

Color of alcoholic specimens: Ifeal dark brown, lighter above; the mandibulary stipes areolate, jale lines sẹparating darker areas; antennac dark brown.

Boxly usually with a yellowish median longitudinal line of grenter or less wiltlı, on erich side of which is a usunlly broater dark line, below this a narnower yellow onc, and then another dark line or longitudiunl row of dark spots. Ventral surface yellow, legs pullit, or the distal joints tlark. On each segr ment the brown color is much darker on the posterior subsegments; that of the anterior portion has sometimes a bluish tinge. 'llhe uncdian yellow line is frequently obsolete, and the lateral reduced to a row of transwersely oblong syots. In the dorsal dark lines there are, on eneh segment, two longitudinally owal or circular small yellow sjots, in which the snall bristle-bearing protuberances are locented. Even when the lateral yellow line is present there is, lesow the outer of these spots " brighter, longitudinally oval spot. The lateral bristle-bentiner protuluerance is located in the upper part of the lateral dark line and is colored yellow. Length $14-16 \mathrm{~mm}$; width 1.5 .

IIabital: In the U. S. Nat. Musemm are the following nunbers labeled Campodes flavicormis by Bollman. While there was supposerl to be but one species in the genus determination was compramtively easp, but it is now impossible to assign specimens to the different species withont a dissection or at least a 
very careful examination of the male genitalia. Hence the determination of the female and young specimens is in the present state of our knowledge impossible, and these and the other reports of the species have value only in showing the distribution of the genus. Sonctimes two species werc found in the same bottle. Nos. 18 and 28, Bloomington, Indinna, largely young specimens. The whole ones have 26 segments; No. 67, Fort Snelling, Minnesota, a female; No. 159 Little Rock, Arkansas, a female; No. 197, Mossy Creek, Tennessee, a female; No. 247, Chapel Hill, N. C., a male, but not dissected; No. 325, Winona Minnesota, immature; Nos. 16, 142, 44t, 448 no localities given, probably from Indiana.

Besides the localities mentioned, specimens of this species have been reported under onc or the other of its synonyms, from the following places :

Alleghany county, Pennsylvania (Wood); Culmana, Alabama, or Ocean Springs, Mississippi (Packard); Monroe county, Indiana (McNeill); Benver Creek, Jefferson county, Wast 'Temnessee (Bollman); Washington, D. C. (Bollmain); -Bloomington, -Ja-Fayette---and Salem, Indiana (Bollmam). We found about a dozen specimens among leares in rather dry woods near the Catholic Lniversity, Washington, D. C., October, 1894. These are represented by figures $138-143$.

The above description was made from the U. S. Nat. MIuseum material (No. 16, no locality given, but probably from Indiana) from which figures 145-148 were drawn. We cannot, however, be confident that either the description or figures apply to the original caesioamulatus. Descriptions under this name have been published by Wood, Packard and McNeill. None of the chancters given by the earlier writers are more than generic, with the possible exception of the size. According to Wood's original description the length was "about an inch." The only species known to us to which this is applicalse is C. major, from Washington, D. C. Wood's type snecimen was from Alleghany County, $\mathrm{Pa}$., and is probably no longer in existence. The only specimens of the genus in the museun of the Philadelphia Academy are a female specimen and a half labeled, probably by Dr. Wood, cresioannulalus. 'They were collected ly Dr. Leidy in West Virginia, and are rather large, of light color, and perhaps more fusiforn than usual, in which chnracters they agree with C. major. 
Packnrd's. material was from Alnbama or Mississippi. The length is given as $15 \mathrm{~mm}$, from which facts if we may infer anything it is that the species studied by Dr. Packnrd is likely to have been different from the type of Wood. The matter is further complicated by the fnct that we have found two distinct species in the vicinity of Washington, I), C., and three in the material referred by Bollmm, and probably also by MeNeill, to C. cresioannulata. One of these Indiana species was described by McNeill, who was the first to give charncters avilable in drawing specilic distinctions.

The description was confined to the ninth leg of the male. He says: "l'he eight* pairs of legs are modified as follows : joints six, $i$. e., femur and tibia, and four tarsal joints united to form $n$ look. The basal joint is slightly lengthened and curved upward nearly parallel to the body. The tibia is compressed, and gradually enlarged to a point one-third its length from the distnl end; from this point it is abruptly constricted so that the diameter of the proxinal and distal ends is about-tho-sane. -The-enlarge-- ment of the tibia is on its ventral side and ends in a tuberele which does not bear a seta. The four tarsal joints (with the distal third of the tibia) form a semioircular hook tipped with a normal claw. The two proximal joints of the look are equal in size, cylindrical, leingth equal to the diameter. The last joints ne conical and very small. The length of the four tarsal joints is equal to the greatest diameter of the tibia. Femur and tibia are white and not pilose, the hook is brown and pilose."

If we interpret this by the light of the accompanying drawing (reproduced as fig. 149), it will be seen that the ninth leg differs considerably from those studied by us (cf. figures 117, 127, 140, $145,162,163,167,168)$. The number of distal joints is different, $\dagger$ as well as the shape of the large proximal joint. What appenrs like a small basal joint is not explained in the description quoted. The description also mentions a tubercle on the tibia, but the figure does not slow it. One of the Indiana species, however, has such a tubercle (ef. fig. 163). 'lhis snggests that the drawing and the description may not have been made from the same

* Iot counting the genitalia.

†This is probibly to be explained by the fact that in the slecimen represented by fig. 145 there is a somewhat obligue ridge acrosy the last joint (ct. figs. 145 and $145 \mathrm{i}$ ). 
specimens, since it is extremely likely, to julge from the Indinn material we have studied, that Mr. Mlcheill's numerous specimens represented more than one species.

In addition to that of the ninth leg, Mr. MeNeill gives a fignre of the genitalia. In his explanation this is said to be plate xii, figure 5. 'This figure ben's no resemblance to the genitulin of Chordenmide, but las evidently been tinnsposed with figure 5 of the preceding plate, which we here reproduce (fig. 150). It so far resembles figure 147 as to make its specific distinctness a matter of doubt. The resemblance between figures 150 and 138 is more striking. Figure 138 represents a specimen collected at Washington, D. C., which wouk give the species a considenble range, leaving it entirely probable that it my be found in Alleghany connty, Pa.; thus the question of what Cleidogona crsioannulata really is seems likely to be settled in one of two ways. Either we must retain Mcxeill's for'm as representing the species lecause he was the first to describe it in a tangible way,-ol'-we must find by collecting whit species is found in the indicated part of Pennsylvania. 'The only clue seems to be the size. The Indiana material we have seen is only $14-16 \mathrm{~mm}$. long. If there should prove to be one species in Alleglinny comnty' 'about an inch' in length, we must call it casionmulata. In the mentime species indicated by MeNeill should have the use of the nume unless a new onc is to be made.

The Wnshington, D. C. specimens (figs. 138-143) differ somewhat in the shape of the gentitalin and ninth legs of male, especally in that the distal joints of the latter are in the Washington specimens short and thick, while those of figure 145 are the longest we have seen. Notwithstanding, there is not the same necessity of distinguishing the forms specifically as appents in the other species in which the genitalin are so different as to lenve no room for doubt.

\section{Cleidogona major sp. $n$.}

Plates VI and VII, figures 110-137.

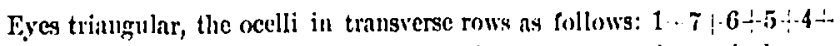
$3 \cdot 2 \cdot 1=20$, in oblipue rows: $1: 1 \cdot 2,3,4,5+6,7=$ or in sertical rows: $8 ; 6-5 \div-1+3-2 \div-1$.

Yale genitalia (fius. 128-130) with anterior irm much curred at lase, nearly stright at apex and bilobed, but not deeply as in $C$. cevionmulala; apical sinus broad and rounded (cf. litr. 129, an apical view). On the anterior 
ventral face there is a deep groove, and some distance below the apex a broad lateral emarginution. Near the base of the posterior arm are a few long bristles. Posterior arm abruptly capitate, iatcmlly with a rounder projection above.

Ninth legs of male (fig. 127) with basil joint broully cuarginate on the ventral side, very prominent above, sometimes truncate; without tuberele. Secoud joint three times as lonir as broal, the line of the ventral sile beingr gently curvel, not with a sharp tum at the grentest dianicter. Distal joints ratler stout, with a similar ridge across the anterion side as described for $C$. cessionmulata. Claw ruther simall.

Color horn-brown, nottlen with pinkish white. Head dark lorown, especially the vertex, mort or less mottled with white in tine points arranged in irregular areas, with more or less bilateral symuctry. Lower purt of clypeus nearly white. Margin of labrum transparent yellowish.

Segments with exposed portion dark brown above, dirty-white below. Anterior sulsegment pale, except where exposel. $A$ pale transwerse line is usually present along the suture between the subsegments; dorsally the suture is especially on anterior segments, sinuate, and sometimes the lighter ${ }^{-}$color rūins $^{-}$ brack on the mertian line. The six sete of pach segment are located in light spots, and between the outer pairs of setic there is a large transwerse area coarsely mottled, bounded in front and hehind by a datrk line. The posterior line is extended below the outer seta and is broaler; $w$ ) that the aninal appears to have a row of lateril spots. Jelow the spots the color ropidly fales to yellowish white. On posterior segments the dark color of the dorsum is iarker than on the anterior, the lighter spots smaller, but more vivid.

I.egs with basal joints dirty white, the distal dark brown.

Antenne very dark, except a short 1 ale ring at the hase of each joint.

Length of mature males $18-20 \mathrm{~mm}$., width $2.2-2.4 \mathrm{~mm}$.; length of females 20-24 mm., witth $2 \mathrm{~mm}$.

Habilul: Washington, D. C. Vine mature specinens, including three males, were collected among leaves on a wooded hillside in the Zoülogical Park, Washington, D. C., October, 1894.

This species, from its great size, secms likely to have been the original of cxsioannulala, and may be taken as the type of the genus Cleidogrona. It also seems more relnted to the species identified by MeNeill as cresioannulata than do the three following species. It is possible that this species is among those reported as Campodes flavicornis, but we did not recognize it among the specimens from the National Museum.

\section{Cleidogona Iaminata sp. $n$.}

Plate IX, figures 164-171.

Eyes as in C. mnjor, ocelli of the sume number, arranger in transverse row: $8+6-5-4 \div 2 \div 2+1$. 
Genitalia of male (figs. 165i, 166i) with the anterion arms obligne, deeply bifid at apex, the lobes subequal, hut of clifferent slape; the inner somewhat resembling in otutline the heal of a bird; the onter more or less truneate and

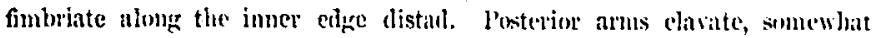
acuminate at apex and with a notely on the median face. Below, attaceled to the anterior arm, and somewhat embancing the posterior is on calch side at thin lamina.

Ninth legs of male (ligs. 167, 169) with the basal joint broad helow aml deeply entarrinate above. From the posterior fate projerts mesul a triangular plate dentate on the proximal elge, partly cosering the enampination, amel giving the apperanece of a deep notel when the ley is viewel from the jus:terior side. Serond joint more slember than in the otler spereies, more than three times as loner as broud $i: 2$. Proximal joints with seattering hatirs, thie distal increasingly hirsute. Claw mother sulnall.

Tenth legs of male (tig. 170) with matgins of coxal apertures proluced, and the inner edge of the coxil somerwhat comiryinate.

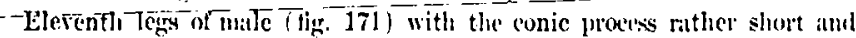
blunt.

Color of alcolonlic specinuens, prohably ficlen, liorn brown, danker above, frmilually changing to dirty white hulow. The spots deseribel for the proceding species are present, but are less distinct, so that the animal appears: nearly concolotous unless more closedy examinod.

Length of male 15,5 mun. : widtlt :? mun.

Hubital: Locality unknown, probably Indiana, Us. S. Sat. Museum, No. 427, a male and two femnic specimens. In the form of the genitalia and ninth legs this species seems very distinct.

\section{C'Reidogoma jorcepas s. 11.}

Plate IX, tigntres lis?-16ias.

Ihle genitalia with anterior arms broth below, grathally narowed, then dilated and again narrowed, decply bilobell at apex, not decurcel; superior

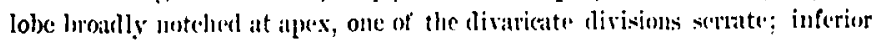
lohe longer, the apex slightly notched, twisted.

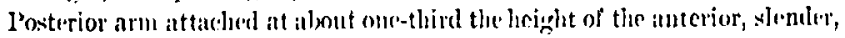
decply divided, forcipate.

Sinth legs of male with hasi joint motrotely emarginate below on the ventral face, slighlty so alowe on the dowil face. Secoml joint searecly twite as long is wide, at about the midlle on tle ventral sidc swollen into a large roumded prominenes: above is it hroul sinws into which the distal joints are folded.

The specimen on which this species was founded was taken from the s:une bottle (U. S. Yat. Inseum Yo. 16, no locality), with those represented log firrures $1+4-148$, and uot apparently

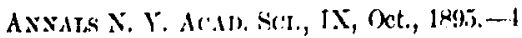


differing from the others in external appenrnnce. The form of the genitalin and nintlı male legs is so distinct and chartcteristic ns to make iclentification easy.

\title{
CIeidogona fustin sp. $n$.
}

\author{
I'late VIIL, firures 151-153.
}

First legs of male six-jointed, the joints, beginning with the coxa, .20, .06, $.30, .12, .10$ and $.38 \mathrm{~mm}$. long; third and fourth joints $.10 \mathrm{~mm}$. Two superior secondary claws and a small inferior one.

Second leys of male nlso six-jointed, the joints .20, .06, .32, .14, .10 and .32 mm. in length; width of third joint .12 mm.

Third legs of male sevan-jointed, .22, $.04, .32, .36, .14, .10 \mathrm{and} .40 \mathrm{~mm}$. in

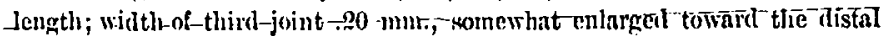
eml. Serenth joint with hook-like transparent roughenings like those of Conolyle fischeri, lut smaller. The third joint with a few conic or knob-like protuberances on the inferior surface.

Fourth legrs of male seven-jointed, the joints, beginning with the coxa, .24, $.04, .40, .44, .14, .12 \mathrm{mil} .44 \mathrm{~mm}$. long. Seventh joint roughened as on third lers. The third joint with a few kuobs, as on the fifth leg.

Fifth legs of male with joints .24, .04, .48, .46, .18, .10 and $.44 \mathrm{~mm}$, in lenuth. Inferior surface of third joint coverel with small knobs abont .04 נmm. in diameter. Seventh joint frith inferior seconlary claw, apex with process like the twelfth lege.

Sixth leys of nalle with joints .28, .0.4, .44, .46, .18, .12, .44 mm. Third joint sparsely covered with cones and knols. Serenth joint as given for serenth legs.

Serenth legs of male with joints .28, 04, .2, .48, .16, .10, 42 mm. long, .26 mm. wide; eoxa with a large transiarent rounded protulurance, alont as long as wide (.06 mm), coverell, like the surface of the coxa, with sparse small knols, smaller than those of the thirl joint. Third and seventh joints as for the sixth leg. Distal two-thirds of inferior surface of seventl joint roughened with crowded, appresserl, distally directed short, sharp, bayonct-like processes. One superior and onc inferior sccondary claw.

Tenth legs of nale with joints respectively .36, .06, .32, .46, .16, .10, and $.48 \mathrm{~mm}$. long, will of third joint .20 $\mathrm{mm}$. First joint thickened distad, and with two large protuberances, one (eonical, the other larger; and of irregular slupe. The first is chitinous, the secoul menibranous, apparently protruled from an aperture. Inferior suffuce of third joint thickly covered with very flat knols. Serenth joint with distal half as on seventh legs. The superior

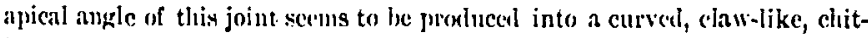
inized proxess nearly eyumlling the true chaw in size. $A$ small inferior secondary claw.

Eloventh lage of male with joints respectively .36, .0.4, .32, .46, .14, .12 and $.50 \mathrm{~mm}$. long; third joint . $.8 \mathrm{~m}$ mm. wille. Coxn with a large irregular process at alvout the midille of the inferior surface, directed meso-coudad. Seventh 
joint with distal half as on seventh ler; near the alex of the joint, and on the upper side a lancenlatc, thin, transparent, twisted process as long as the claw. No seemilary (laws.

Twelfth legs of male with a large, blunt, comical median process on the pedigerous lauman, directed ventro-replahad.

Genitalia of male (figs. 151-1533) viewed from lrelow (anterior face) with the anterior arms dilated aboye the middle, sudelenly twisted at inex and deeply bifid, one of the divisions longr and grently curved. the other broul and in some cases at least, perforate.

Posterior arm simple, clavate, the anterior corner above slatrp and sonewhat producel; on the same side a short distance below is a tooth-like prominence.

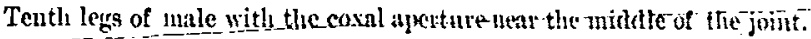

We have examined two male specimens, U. S. Nat. II useum, No. $\mathbf{4 6}$, no locality given, but probahly from Indiana. Externally they did not appear different from the other species.

The mensurements of the joints of the legs were male with a view of finding ont whetiler specific differences existed. The relative proportions appear to be. maintained, so thint it does not scem necessary to introduce meisurements for the other species.

\section{Cleidogona vudii (Cope), 1 Eitig.}

Pseudotremiat rudii Cope: Proc. Aner. Philos. Soc., XI. p. 180.

- "This species differs from the last (Peudotrmia coternarum) and resembles rather P. cresioamulatus of Wood. The points separating it from the latter will be pointed out below.

"Number of secments the same as in the $P$. carcmarum, twenty-vine, hut they are neither envex or rugnese nor coatsily striate, but maked with a very minute, irregular longitudinal striation. Segments cylindric, without shoulder, but with a small clirected backwards on the posterior margin of the lower part of the ammulus, which is cnlarged on the front segments. This eleration is furnished on the anterior and posterior refrions, and probably everywhere in an uninjucel condition, with a bristle. On the anterior segments a hair in front of ench pore. Front plane, with finer and coarger lairs sparsely distributed. Jatemal marrin with an open noteh. Autemuse hairy, with a bristle at the distal extremity of each. joint. Ifengthe, 34,5 th, 4th, 2l, 8th, Fth, 1st; the eighth joint longer than in $P$. corechorum. Eye pateh triangular, not in a dlepression. I'osterior segrments considerally compressed, thie last segment with four transparent malginal bristles; extremity of boly slightly recurved. Total length cleven lines.

"Color pinkish-brown, with a pale band from below to the ex. termal pore on each side of each aumulus. 'lop of head black. 
" $\Lambda$ single specimen, to exact locality not preserved, but probably from Montgomery Co. (Va.), and, I think, not from a cave. I have conferred on it the nume of my friend, l)r. II. C. Wood, Jre, to whom we are indelted for a system of the Myritupoda and the menus of sturlying the American species. It differs from the $A$. cresionmelatus of his monograph in the romeled dorsum without keel oir groove, the 29 instend of 32 segments, and the coloration. The eye patches are not in a depression, nor is the labrum deeply' emarginnte, as Wood describes."

Cleidogona mexicanus (Humb. et Siuss.).

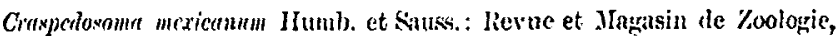
1809, 1. 153; Etudessur les Myringoles (\%oologic du Mexiquc), p. 59, $18 \pi^{2}$.

\section{Plate VI, figures 105-109.}

Boxly cylintrical, smootli; shining, slightly attemuate cephalad, strongly so caulad, laterally conpressed toward the extremity and teminating in a point.

Heal fattened in front, its lateral and superior parts swollen and projecting, the vertex forming an arched prominence concave behind.

Eyes forming a triangular plate bchind the antennie.

(irathodilartm (sce plate).

First serment narrower than tle second, forming a constriction behind the heal; anterior border simuate, the middle projecting and arcuate, correspondinge to the (malrgination of the oceiput; its lateral lobes sharp and lent downward, bearing a small horizontal carinib which is continued along the anterior border as a niatyinal threal-like clevation.

Sulsequent serments gradually lararey, truneate below with rounded angle; dorsil line extremely fine. Each segment (the preanal excepted) earrying at half-height a small, pointed tuberele, directed lackward, and terminated ly a lomer bristle; and besides, on enel side, between this line of tubercles and the dorsal line, two other lines of very small piligerous grantules, lookingr sometimes like piligerous points. On the anterior segments the lateril region situated below the line of tubercles is striated.

Jaist segment forming a triangular arch, compressed, molerately truncated at the cxtrenity; the truncated borler ornamented with small spines (3?).

A mal valves marrow, compressed, forming a crest which projects as far lackwards as the extremity of the last segment.

l'reamal scale roumeled.

J.ers long, slentler, completely covered by a fine villosity.

Color chocolate brown, paller below, posterior horier of segmenfs ormamented by a grity bame; thr sulall tubercles forming spots of lighter color surrounded by a palc ring. leet and anteme pale.

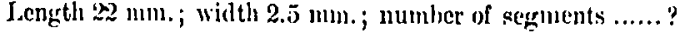

Hebilat: Katstem Cortilleras of Mexico. 
The above is a translation, partly rearanged, of the description given in the 'Etules.' It seems to have beon' based on one female specimen. The atuthor's acld the following remark:

": 'This species is cridently very nearly relnted to Spirostrephon cxeionmulalus, Wood. but judging from the description and figure, Mr. Wood's species scems not to have upon the sides a row of tubercles larger than those of the dorsil surfice. If Mr. Wood had not given thirty-two segments for his species, instend of thirty, we would not doubt that it should be included in the

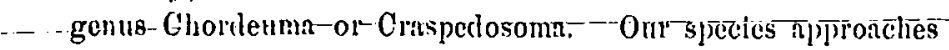
Craspedosoma, Ieach, in the form of the gnatlochilarium, and the development of the piligerous' tubercles, and Chordeumi, Koch, in the eylintrical form of the body."

\section{BACTROPUS gen. nov.}

Eyes of mumerous (27) prominent ocelli armanged in triangular patches.

Antenne long and siender; third joint longrest, nearly ecfuatled by the tifth $(10: 9)$, followed by joints $4,2,6,7,1$.

Sandibles with ten pectinate lamellic.* *

Promentum not tlistinet.

Segments with lateial carina represented by a gentle bulging of the surface; not striate; setjgerous tubercles obsolete, the setic slort.

Ialc genitalia simple, lamate.

Ninth legs of male live-jointel aml with a small claw; coxa much larger than the other joints taken together.

Segments of adult 30 .

This genus resembles Cleilogona in general appethince, but the borly is smaller and more slenter. It also has chancters in common with Pseuciotremia, Irichopetalum, and Conotylat. From I'seudotremin it differ's in the better development of the eres, being evidently an open-tir ereature; also in the lateral carina nearly obsolete and the lateral surfice not striate. It resembles I'scudotremia incl Cleidogronit in the slight development of setigerous tubercles and in the number of joints of the ninth male legs. This last resemblance is, lowerer, only :tplatent, for the form and function is very different: In P'sendotremia and Cleidogona the ninth legs ane (ulpable of use as clasping organs, while in Bactropus, as in Trichopetalum, it is difficult to moderstand how the ninth legs could serve such a purpose. Bale-

* The coudition of the specimen was such as to make the number somewhat tuncertain. 
tropus also differs from the genern mentioned in the number and sliape of the joints of the ninth legs, the slight development of carine, tubercles, and bristles, and in the want of . distinct promentum.

\section{Bactropus conifer sp. $n$.}

Plate IX, figures 172-176.

Body tapering more gradually behind than in Cleidogona.

- Fertex-slightly rugulose, sparsely hirsute; sulcus indistinct.

Eyes triangular, armuged in six rows, beginning posteriorly; $7: 0 ; 5-4-4$ $3+2=27$.

Autenne slighly clavate, approximate ratio of lengths of joints, beginning with the serenth, $3,4,9,5,10,4,1$.

First secrment rugulose, semi-circular, the tubercles very nearly obsolete. The furrow in which the dorsal ridge is situated runs nearly, if not quite to the anterior maryin.

Subequent segments slightly rugulose, anterior portions finely reticulated, carine small, tubercles and luirs very small and indistinct. P'sterior margin gently siunate on cach side belind the onter setigerous tubercles.

Iast segnent, ana! valves anl preanul scale (figr. 176 ! much as in Cleidogona.

Malc genitalia (fig. 17.4) simple, with broad lase and attenuate njex, curvell bickward.

Ninth legrs of male (figs. 174 and 175) with a few hairs on the two proximal joints; the claw very small.

Color dark brown, the posterior margin of each segment and a very fine median line yellowish. A light spot at ench setigerous tubercle, the outer two spots on each sicle sulcoulluent, givingr the apyeatrance of a light longi...tudinal line. Ventral parts and bakil joints of fect dirty brown; apical joints darker. Antenna nearly black, darker than those of any other species known to us.

I.engrth about $9 \mathrm{~mm}$.

Habital: Indiann. We have examined one male and thee female specimens collected by Bollman in the vicinity of Bloontington, and deposited in the National Musem (No. 43) under the nane "Craspedosoma lumalum."

The material is in poor condition so that many important facts cannot be determiner. Further study will probably multiply minor similarities with Cleidogona.

The joints of the ninth legs of male are not, in the specimen examined, easy to distinguish, the sccond, third and fourth appearing nenrly coalescel. This suggests the idea that the second joint of the ninth leg of Scoterpes, 'Trichopetalum, /ygonopns and Conotyla may have been formed by the grachal coalescence 
of the four distal joints. Indeed, this iden becomes reasonably probable when we consider that there is a claw in Scoterpes, and a similarly located ehitinous bunch in \%ygonopus and T'richopetilun, which may be interpreted as the rudiment of a claw. It shonld also be noticel that in P'seulotremia and Cleidogona there is evidently a tendency towarl the development of two large proximal joints at the expense of the distal.

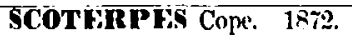

Am. Yiat. VI. p. 414.

Spirostrephom (Ise'ulolsemia) Packarl and Ryler, not Brandt.

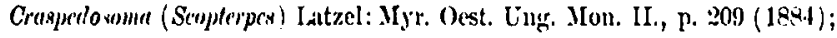
Haase: Keitsch. f. Fintom., N. F., XI., p. 60 (188(i).

Fyes wanting.

Antening of molerate length, third joint longest.

Serments with molerutely prominent shoulder-like carines.

Ninth pair of lens of male two-jointed, the distal joint with a strong claw. Serments of adult 30 .

The single species of this genus is from Mammoth Cave. It is known to us only from descriptions and figures, but there c:un be little donbt of its close relationship with \%ygonopus and Trichopetalum, from both of which it is distinct in the large claw of the ninth legs of the male. We reprorluce Dr. Packard's figures of the genitalia and ninth pair of legs, but it is not possible to get from these or from his descriptions a satisfactory idea of these structures, nor one which will enable us to compare them with allied forms. Indeel, we are not certain that the ninth legrs of males onght not to be spoken of as three-jointed. In IDr. Packard's figure they appear entirely detacherl, and if the two joints are correctly dirwn another would seem necessary to connect them with the looly.

It is in this genus that the six dorsal bristles peculiar to the present family have their greatest development. According to Drs. Cope and Packard these bristles approximate in length the diameter of the hody, giving the animal very much the appearance of a caterpillar.

Scoterpes copei (I'nckurel) Cope.

Spirostrephon (Parmlotremia) copre Packural: Am. Nat. V., 7.18 (18i1).

Scoterpes copci (P'ackard) Cope: dm. Sat. VI., p. 414 (1872); I'ackard:

Proc. Am. Phil. Soc. XXI., p. 1933 (189.3); MeXcill: Bull. No. 3, Brookville Kos., p. 8 (1898).

I'lite I., figures 12-13. 
"Heull with wather short, clense lairs; no cyes, and no ocular clepression behind the antemne, the surface of the ppicranium being well rounded to the antennal sockets; behind the insertion of the anteme the sides of the head are much nore swollen than in $S$. Inclarims.;

Antennie slender, with sloort, thick laais ; relative length of joints, the 6th

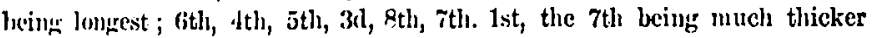
than the stll.

Twenty-eight segments behind the head ; they arc entirely smooth, striated neither lomeitudinally nor transversely ; a few of the anterior segments rmpidly decrase in rliumeter toward the head. The equienty are but slighitly convex, and on cach side is a shoulder, bearing three tubercles in a tmusverse row, cach grivingr rise to a long stiff hair one-half to two-thirds as long as the segment is thick; these hairs stand up thickly all over the luck, and may serve at once to distinguish the species.

No pores.

Fect long and slender, nearly as long as the antenne, being very slender towarks the claws.

Color entirely white.

Length of boily .35 inch; thickness .04 incls."

Hetrilut: Manmoth Cave, Kentucky.

'The above description is that originally given for this species. 'l'he importance of several of the included statements is questionable. especially since the accompanying diagrams do not arree with the description.

The antenna are said to have eight joints, while in the dingram but seven alpens. In giving the "rolative length of joints" the second is entirely omitted, so that we have no ground for supposing tliat there was a synall basal joint not given in the diagram and are obliged to fall buek on the fuct that in this fanily the antenua liave, as far as known, but seven joints. It might also be noticerl that if " $2 \mathrm{~d}$ " is unclerstoorl for " $3 \mathrm{ll}, "$ " $3 \mathrm{~d}$ " for" " 4 th" and so on, the relative length of joints will be the same as 'Trichopetalum, jth, 3il, 4th, 2il, 7th, 6th, lst.

The drawing of the entire animal also gives thirty segments insteal of twenty-eight. as in the riescription.

At al later dite Di: Packard gires a more extended descriptiont of this species and gents, differing, besides, from the former leveription in some important particulurs, so that it seems desimble to add a trunseription of it. 'Tlhese descriptions con-

" Dr. lakkard wrote this whilc believing the present species to be congeneric with Lysiopstalum lactarium (Say).

$\uparrow$ I'roc. Am. Philos. Soc, XXI, p. 177, Sept. 1883. 
tain, howerer, many statements which we look upon as of doubt. ful import or questionable truth, and such are griven in italics, our reasons for cloubt being stated later on.

"Borly very long nud slemler, uot furiform! consisting of thirts scuments besides the head, wilh about fifty-fu'n putios of legs, wilh llwe penulliwute joint rery lomy. Head mather large, and unustally broat; no eyes present; the geno unusually large, but not so grolose as in Trichopetalum; the front is also collricd farther up on the certex then usterl, and is merh browh then long; the

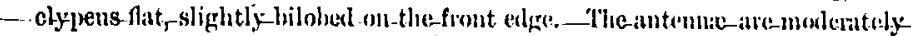
loner and hairy, with the sixth secrment scarcely longer than in 'Trichopetalum, but more uniform in thickness, scarcely longer tlin thick; the triminal joint as long as the sixth, the end conial, more produced thun in Trichopetalum

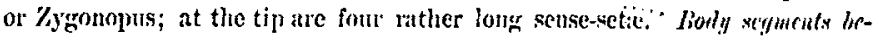
coming as usual smmller next to the hetrl; the anferior of ench division of the arthromer muh swollen high up on the sicles; each shonleler with three tubereles, which are arruged in a senlene triangle and bearing much longer setec than in the other genem, though not quite so long as the bong is thick. The legs are lomy and slender, more so tlan in Trichopetalum, and somewhat more than in \%yonopus, In the male the eiglth pair of lens are rudimentary, being two-jointed, the second joint ouly one'-fourlh longer thrm the busal, and ending in a well-teveloped stout claw. The genital armiture minute and very rudimentars, pale, scarcely clitinous; the outer laminil shot and thick, with a stont external recurved spine, and two terminal oht use points; the inner_lamina shorter, forming a truncated angulat spine, and not much more than half as long as the outer lamina; between the inner and outer lamina, its lase next to the immer lamina is a midhlle spine ending in an irregular tuft of fine spinule's.

"This gremus is distinguisherl from Trichopetalum by- its want of exes, its

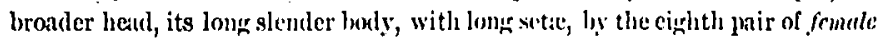
rudimentary legs ending in a claw. From Zygonopus it differs in the shorter sixth antennal joint; its brokter head; its slenderer legs, the sixth pair in the femnle not being unlike the others, and ly, the more prominent shoulders and longer set:c. The species of the two generi are of the sume greneral form and вize."

"Ahout 208 and \& exanined. Jonly white, with no dusky diccolorations; 30 segments belind the head in specincess $11 \mathrm{~mm}$. in length amd is pairs of legs; in one female inlividual ox mm. longer there were 49 paiss of legse, including the eighth or rudimentary pair ; in another individual 6 mm. Iong there are 2.1 segments behind the lical. The heal is proviled with sliort, fine erect hairs of clifferent lengthis, especially on the sicles of the gretie."

"Males and feminles are alike in size and form."

That the body is "not fusiform," lut that the segments become, "as usual smaller next to the heal," seem to us mutually" contradictory statements. In all the Chordeumidis known to us the last joint of the legs is longest, not the ponultimate, though 
this is not necessnrily the implication of Dr. Packirl's statement, What is intemled by the front being curried up on the vertex, we cannot imagine. In the species known to us it is practically impossible to make out any definite lines of division between these purts of the hearl. "Femnle," is twice used where "male" was eridently in:ended. I)r. Packard was of course aware that in chilognaths the eighth legs of females are unmodified. 52 legs rould be a most unusnal number for allowing one pair of legs ench for the 1st, 2l, th and 28 th segments, and nore for the $3 d, 29$ th and $30 \mathrm{th}$, there can be but $50 \mathrm{legs}$ on a female chordeumid, 48 or 4!) On a male.

I). Patckard's figure (see pl. I., fig. 13) of the ninth pair of legs and the genitalia gives us no idea of the method of attachment of the former, and the length of the second joint does not correspond to that given in the description. A laciniate process is probibly present as in /ygonopus and 'lrichopetalum. but in other respects-there is a wide difference from those types, and a further study of the species will probably prove very interesting.

Reasoning from analogy and from the statements of the writers quoterl, we suppose that this species has unlergone the same deterioration of the exoskeleton as is deseribed for Zyggonopus uthitei.

Regarding the distribution of this species, Dr. Packind adds:

"The specimens, were most abundant in the Ialyyrinth in Mammeth Cave, but also oceurred in other lonlities in the cave. It is also common in Diamond Cave, where I collected it, and was diecovered by Mr. Samborn in I'oynter's Cave, 300 yards from claylight. In one of the slecimens from the lastmentioned care, the antemic are rather more slender than usual.

"The genus Scoterpes, and its single species copri, appears to be limited to Mammoth Cave and the others near, in aluarently the sume system of cares. It was erroneously reported by me to oceur in Weyer's and the Itury Caves, as the specinn'ns collected belong to K,yonopus whilei. Without doubt the genus is a moditicd 'Trichopetalum, which has beconse longer and slenderer in bolly, with longer legs and antenue as well as seta; whether it is a lesendant of 'Trichny fulum lumulum or not is uneertain; it mily lave descenderl from a different species; but there suems to be no rensonable dount that it is a modified form of a small hairy lysionetnlid form, with antenule exictly like those of 'Trichopetalum."

Dr. Packard's sections led him to the conclusion that the present species is as truly eyeless as a Polyelesmus. All traces 
of eyes, with their accompanying nerves and ganglia having disappeared. A compensating hypertroplyy of the olfuctory organs is notecl.

ZMgONOPLA Ryler. 1881.

Proc. L. S. Nat. Musemu, Vol. III, p. 524.

Zygonnutes, Packard: P'roc. Amer. Philos. Soc. XXI, p. 194 (1833).

Eyes wanting.

Antenua-rather-stont, subclavate, difth joint longesteiud thickest

Mandibles with eight pectinute lanelle.

Promentum not distinct.*

Segments with molente, sloulder-like carine, the surlace delicately areo-

late, appeiring smooth; setigeroms tulbercles prominent, setic long.

Inle legs with last joint not hispicl.

Coxn of secont male legs with conic processes; legrs without the cusition-

like processes juresent in Conotyla.

Sixth legs of male nuch crissitc, expecially the fouth joint.

Male genitalia simple, cousisting of a decply bifid lamina and two laciniate? processes.

Ninth legrs of male two-jointed, the distal stout, oleluvate, with a small chitinous knob on its outer face.

Segnents of adult 30 .

Distribution: Luray Cave, Tirginia.

On account of the small size of the animal and special difliculty of manipulation, we were not able to satisfy ourselves whether the coxa of the tenth and eleventh pairs of legs of the male are perforate.

In many of its characters this genus shows such evident and close relationship with 'lrichopetalum that we have sometimes doubted its validity. On the other hand the character's by which it is distinct from that genus ( $p . !$, want of eyes, swollen sixth legs of males, corric process of seconl legs, and 30 segments) are so numerous that there seems ample ground for retining it.

The similarity to Scoterpes is probably even more striking, since both are cave animals, lack eyes, and are more or less soft-lodied. We have not had the opportunity of making a stully of Scoterpes, but retain both genern, helieving that the differences in the sixth and ninth male legs are sulliciently important to warraut such a conrse. nud that these are inclicative of the probable existence of still other differential characters.

* The microscopic preparation was not suficicntly successful to make this certain. 
The importance of diflerences in the ninth male legs as diagnostic generic charncters is evidencel by the fact that forms so different is 'lrichopetalum and $Z_{y}$ gronopus have these legs almost undistinguishable (of. figs. 21 and 43) even to the presence of the small, more or less chitinous lumeh, possibly the ruliment of a claw on the lateral face, near the apex. Conotyla has a similar form of ninth legr, but does not have this bunch, and differ's widely in other chanacters. 'These ficts are suggestive of the probable inportitice of the farge clat-on the niuth legs of Scoterpes as deseribed aud figured by I)r. Pasckaxd (ef. our figure 13).

\section{Hygonopus whitei liyler.}

spirostrephon copri I'ackard pro parte: Am. Nat. XV, p. 231 (1881); Proc. Amer. l'hilos. Sox. XXI, p. 194 (1883).

Zy!mounpus uhitei Rydler: l'roc. U. S. Nat. Museum III, p. 527 (1881); Mic.Yill, Bull. No. 3, Brookville Soc. p. 9 (1888).

Plates I-II, figures 14-2I.

lody scarcely-fusiform, slightly broalest toward the front, marrowed very aluruptly on the last few pesterior seoments.

Vertex with a lange, shallow, transversely oral depression between the antomute.

Clyjeus with a large traussersely oval depression in the upper part.

Antenue of moderate length, subelavite, morlerately pilose.

linerub! lobes with three seuse-cones.

stylitorm pricess decply quadriclentate.

First serment louger than seini-circular, regularly roumled in front, nearly straight behinl, lateral comers not producet. Outer lyistle directed outwardly aml lipwardly; and locited at the posterior cornel. Second bristle mesid and cephalad from the outer, and about as far from the anterion margin of the serment as from the lateral bristle. Inside bristle mesud from the second, and ahmut cyually distant from it and from the median line.

Second segment slorter than the lirst, and with longer bristles.

Thirl and sulssequent seerments with rather small lateral (airina, on which are Jocated the two outer lristles, the inner one of which is somewhat anterior to, antl but little alove the outer. The jnsile bristle is rather slose to the others, receding from the median linc. All the bristles are slightly curved, and the length of the longer is about two-thirds the diancter of the borly. Surface of the kegments dorsally with irregular longtitulinal wrinkles. Below the earime the sisles of the lykly are very delintely striate, after the manner of the Inlidic, except that the striations are much finer and more curved, esprially the upper ones. These striations are very much slighter than thore of l'schulotremia and are much more numcrous, numbering about twenty, On the anterior portion of the sulscermont they are reticulately joincd. All the segments, including the last, have a tine modian sulcus. On 
posterior segments the loristles tend to separate from eawh other and tu anrange themselves in a tamsverse row; the insile pair appresch on the posterion surments very close to the median line.

Anal segment short, posteriorly broally truncate-emarginate, with right bristles. The anterior two located near the median line and close to the anterior elge of the segment. Losterior six bristles much more sleneler than the others, located alongr the posterior marrin at about exulal distances from cacl other. The midclle pair are not quite so elose together as the ofler's, and have papilliform enlarged hases about one-fifth as long as the excetingly line flexible hair that proceeds from them. 'Tlis sextent, ats well as a fow prececolingr, and the anatratses is supplied with it seanty, short puhescence.

Anal valves moderately convex, producel pusteriorly into a tather-tump point, considerably exceelingr the last segrment. Surface linely vertically striate-wrinkled. Margins not mised, the three bristles very slender, almut equally distant from ench other and from the apex of the amal sigment.

Pre-anal seale small, semi-cireular, with two very tine longr bristles.

Sule genitalia (plate II, ligns. 20, :21) simple, of a thin deeply bibohed lamina. the lohes apieally decurred and bidentate, the teeth long and connivent. The anterior face is hispid at base with short hairs, which grade distad into payille; a few long varionsly eurvel hairs near the bottom of the tissure, and a few others near the margin distad. On the posterior side (ligr. 21) splriugring from near the base of the lamina are two phirs of plumose-laciniate preseses, the inner pair mucli shorter', and laciniate on both sisles.

Ninth legs of male two-jointed, the basal joint perpenticular, charate, with a few long bristles towath the apex, one of which is longer than the others and curved lxasnlly. This joint panses insensibly into a menblamous lamina which connects the two joints ind is not interrupted medianly. Second joint oblong-oval, with a-few bristles near the upuer and lower maroins. On the lateral face near the apex is a rounded chitimus knoh, which may be intorpreted as the rulinent of a claw.

Color in alcohol, dull white.

Length 9 mm.; width , 4 mm.

We have latd for study one male specimen collected by IJr. J. M. Underwood at Lumy Cave, Tirginia, September, ISST.

The body of this species is nearly eylindrical, that is, less fusiform than any other known to us.

Owing probably to the cave life of this species, the exo-sketeton usually so hard and brittle, is soft mul flexible. Psemlotrenia has not suffered so much morlitication, as the presence of eyes also testifies. 'l'here alppears to be very' little curbonate of lime present, so that on drying the skin of an aleoholic specimen shrivels up like that of a spicled. 'The legs and other parts wrinkle instead of breaking, and tend to become distorted in matuipulittion. Fven the month-parts are eviclently softer than in the open-air genera. 
Another result of this condition of things is that the joints and sutures are not so evident, and the distinction between the mentum and promentum appears to be obliterated. 'The mentum, as well as the surrounding parts, is merely membranous, and no flexibility would be added if the usual joint were present.

TRXCHOPETALM ITarger, 1872 (emended).

Am. Journ. Sci. and Arts IV, 117.

Crrmprifosoma, Jatzel and Bollnan; Scotcrpes Bollman.

Eyes molentely tevelopel, of severul (10-14) ocelli arranged luntely in two or tlire curved rows.

Antenue rather short, elavate; - thitrd and fifth joints-subequal in length.

Mandilıles with nine prectinate lamclice.

l'romentum present, triangular.

Serments with molerately prominent, shoulder-like curine.

Male less with first joint not hispid.

Third, lourth, fiftl and sixth legs of males strongly crassate.

Ninth pair of legs of male two-jointed, the distal joint broadly clavate, unarmed except that on the outer face of the lnst joint, nenr the apex is a small, blunt, chitinized knol, possilly the rudiment of a claw.

Tenth and eleventh legs of male with the coxe perfornte.

Genitalia of male consisting of a single juir of decurved structures hirsute antero-hasally and with plumose-laciniate processes posteriorly.

Segments of adult 28 .

Distribution: Northeastern North America.

The original description of this genus leads as follows :

"Sterma not closely united with scuta; third and fifth juints of the antenne elongated ; senta furvished with bristles; no lateral pores ; eyes present."

It will be seen that these characters, with the exception of "eyes f)resent," are applicable to all Craspeclosomatidac. Indech, it is probable that the genus 'l'richopelalum would not have been erected laad not its anthor been misled by Gervais' figure into the supposition that in Craspedosona the pedigerous lamine are coalesced. But notwithstauding that the generic chancters originally alleged are entirely insullicient, there ean be no doubt that in IIarger's Trichopetalum lunalum was discovered a generic type, and we have preferred to retain the name, supplying other characters for the generic diagnosis.

In comparison with this genus the anterior legs of the males of \%ygonopus tre remarkable for their slentemess, only the sixth legs being comparable in size with the corresponding ones of 'Trichopetalum. 
The species of 'l'richopetalum which we have studied have the ninth legs of the male (Fig. 43), apparently exactly alike. They differ from those of $/ y$ yonopus in being somewhat clavate, in. stead of olclavate.

The fifth joint of the antenne is equal to or longer than the third in this grenus, \%ygonopus and Underwoodia, while in all other American species of the funily the fifth is sloorter than the third, never bearing a greater ratio to it than $8.5: 10$. In this species, too, the fourth joint is aliont half the length of the fifth, while in Conotyla the fourth and fifth are subequal.

We are nequainted with three speeies falling inder this gents, as here characterized. The original description of Trichopelalum

- tūnatunt gives-no-characters not common to all three, but the figure of the genitalia, on the other hand, does not bent any close resemblance to those of either of the species known to us, although it is possible to imagine it as having been mule from either of them. It is thus impossible, without a study of his type, to know which of our species, if any, was described by IIarger. Under these circumstances it would secm that the course least likely to canse confusion is to lescribe on three species new, giving figures of the genitalia, so that when the type of $T$. lunalum is studied a definite conclusion maty be facilitated and the specific name not misappliel.

\section{Trichopetalum lunatum Harger.}

Trichnpetalmm lunatum Harger: Am. Journ. Sei. and Arts, IV, p. 118 (18\%2); Iiyiler: P'roc. L. \&. Nat. Mus, V, jei (1892); Packarl, I'roce. Am. Jhilog. Soc. X.JI, 192 (1883); Mc.leill, Bull. So, 3, lirowkrille Six. $8,(1 \times 88)$.

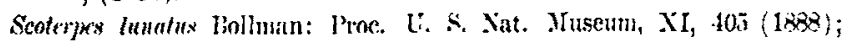

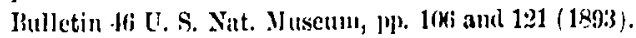

L'late IIT, fifrure's 5i2-5.t.

"Dirty white, Landed transiersely and unttled with light brown nuteriorly. Segments 2N; males with Li, females with to pairs of lers. Ilead large, dilated laterally, covereel with short, cret, hristly hairs. Eyes of 10 ocelli, in a lunate group, comvex towarl the hase of the antemuse. Antemus pilose, seren-jointerl; the joints meisure, the first .0\% mm., secomol: $10 \mathrm{~mm}$., third .23 nm., fourth .11 mm., fifth .22 mm., sixth .09 mm., serenth .07 um. Fingt scutum nearly somicireular, with the posterior margiu slightly concive. Near the outer augles of this scutum are two snall tuhereles on eich side, ench bearing a stout bristle, and higher up a thirrl tuberde on cach side also hears a bristle. The remaining sentat throughlout are furnisherl with threc bristles 
ou each side, springing from tubercles, the lower two being approximate and situated on the upper surface of the short lateral processes, and the thind higher up on the seutum. On a few of the posterior seyments these bristles are in a triusverse row, and on the last sentum, which is broul and truncate, the two inner ones are thickened at their listes. Fliere is an impressed dorsal line. I.egs slencler, white, hairy, with the penultimate joint lengthener. The undel' side of the serenth segment of the male is furnished anteriorly with a pair of appendages directed backward and curver upwarl, and pow teriorly with a pair of cylindrical jointerl organs, directed horizontally outward, tipped with a short lnistle, mul appentring like molified legs of the posterior subsegment. In chawlinge these organs lave a motion similat to that of the basil joints of the aljacent legx. I.ength 6 mun.

"This sprecies is not uncommon under or among decayiner lenves in moist wooks nbout. New Haven."

-. - We-have-copied abore the original cescription of this species, although a large part of it consists in an enumeration of characters common to all Craspedosomatida, and nothing diagnostic of a species is mentioned, with the possible exception of the form of the ninth legs of the male. The accompanying diagram of the genitalia and ninth legs, we reproduce (plate III, fig. 54). If correctly drawn by Inarger, it certainly represents a species not seen by us, as a comparison with our diagrams of corresponding part will show.

\section{Trichopetalum album sp. $\mathrm{n}$.}

l'lates II-III, figs. 22-29, 36-4is.

Eyes in a lumate pitch; the neelli counted from the exterior edge show the following arrugement: $4:-2 \quad 2 !-1 \div 1=10$, or $4: 2-2-2+1=11$.

Antenne somewhat elusite, $.7-.8 \mathrm{~mm}$. long, the fiftli joint thichest, .12 mm. in diameter; approximate ratios of length of joints:3:5:10-11:5.5:10:5:3.

Jingual Jolses with three sense-cones.

First senment lnoully reniform, with mather pointed enls, mot twice as broal as long (5:3), with three setigerous tuberclis on cach side, one near the posterior angle; the second cephlalad, ausl semewliat mesal of the first, near the anterior marrin of the sernent; the thirt alout mid way letwe(n the first and the median line, and situated in a latge shallow depression. A delicate raised anterior margin. P'osteriorly the scrnent is brondly emarginate. A delieate median line begins in front of the middle and extends to the posteriol margin. Surfice smothl and shining, or faintly areolate.

Subsechuent sigunents with the lateral cariud gradually increasing in size to alout the middle of the lorly, and then decreasing so that the posterior serments have mo distinct entin:e. The second pair of bristleg are gradually placel more directly mesud from the onter pair, and on the terminal segments the six bristles are inrmuged in a straight transverse line. The anterior seg- 
ments are broally enamginute pasteriorly. I'usterior dorsal part of segment smovotlier than the anterior, and diviled from it ly a more or less delinite transverse gently eurvel line. In front of this line the surface is finely areolate, behind it smooth and shining, with a few faint, usually longitudinal lines dividing it into layger arrolations. A very tine merlian riolge, located in a nearly olsolete furmow. Below the lateral carina the posterior subsegment is longitudianally striate.

Anal segment short, bually truncate, latenally broally sinuate; medianly the margin of the truncation is slightly produced, giving a convex ellge between the thickened papilliform leises of two long, excedingly fine hairs which are, lases includel, three times as long ins the exposed part of the anal segment. At the curls of the truncation are two slender bristles, and one farther down on the sinuation. 'Two smull loristle-leetring tubercles on anterior part of the seguent close to the mellian line.

doul valves smooth, not strongly couvex, more prominent above the middle, and with a roundel angle, faintly maryined; near the margin on each side threc slenter hristles, oue close to the superior enge of the valves, the second near the angle, the third about half-way from the angle to the edge of the pre- amal scale.

Prennal seale semi-elliptical, posteriorly truncate; two tubercles with long posteriorly directed setie, near the posterior marrin; surface smooth.

Ifale genitulis (ficrs. 3fi-43) sinple, consisting of a pair of more or less areuate, lukally and haterally hirsute structures, behind which are two pairs of laciniate processes. The apices of the genitalia of different specimens appenr to vary consilleribly, but in all cases the end is somewlat broadened and emarginate, so as to leave the corners more or less produced, as shown in fig-" ure 36. The apical portion is fattened and very thin and the different ways it may be bent and the different angles at which it is conseguently viewed will largely explain the apparent variation. 'The form shown in figure 41 is nearly or quite the same as the others, the apparent differeuce being caused by the fact that one of the corners is invisible on account of perspective, while the other is recurvet.

Ninth lens of male oblong-clavate, with a few seattered hairs.

C'olor white, sometimes reticulately mottled with light horn-lirown. The exo-skeleton is so trunsparent that the contents of the alimentary canal, if dark-colored, show through as a dark median line.

Length $6 \mathrm{~mm}$; ; witlth .6 $\mathrm{mm}$.

Halvitat: Common in moist, woorled localities in central New York and western Ontario. We have cxamined about 200 individuals collected at Onativia, Marcellus, Syracuse, Pratt's Falls and Kirkville, New York; also at Orillia, Ontario, and Chief Island, Isake Couchiching.

On the anterior serments the setigerous tulereles are little

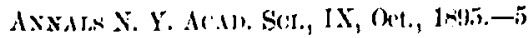


more than a circular ring-like base for the sete, while toward the posterior end of the boly they become distinct prominences.

We clescribe this species with the expectation that it will prove to be Harger's lunatum, and consequently the type of the genus Trichopetalum, if the original specimens can be re-examined. For the present, however, it claes not appenr warrantable to make a determination, for the reasons stated under 'T'. Lunatum.

\section{'Trichopetalnm cornutum sp. 11.}

Plate III, figures $46-40$.

Tery similar to T. album, but, somewhint larger, the lateral. striations more regular and more pronounced, the elevations lateral from the median seta more prominent, the arrangement of the ocellisomewhat different, but rliffering more especinlty-in-the-male genitalia. These differ from album in having the apex deeply bilobed, the lobes more or less comnivent, figure 49 being a lateral view. Fignres 46 and 48 we were able to understand as being the same in form as 49, the apparent differences being conused as in allum by the fact that the apical portion is so thin as to be hent in different ways, and is riewed at different angles. Figure 47 did not so ensily homologize, but it is not impossible that it inay do so, and as we hand but one specimen it seemed best to include it here for the present.

The specimens of this species are in rather poor condition, with the setie nearly all rubbed off. The remaining setre are considerably shorter than in album, but may not be entire. 'The color is uniform dirty yellowish, without a trace of the brownish motthings of $T$. album. This may result from their bcing eave animals.

Habitat: Indiana, Bloomington and Coon's Cave (Bollman). U. S. National Museum. Numbers 24, 42 and 441.

The Bloomington specimens are mixed with those of the following species. Eight specimens referred to the present species have heen extmined, lut in their present condition the determination cannot be made with confidence without dissection sutlicient to show the male genitalin.

\section{Trichopetalum uncum sp. 1.}

P'late III, figure 51.

Very similar externally to the two precelingr species, but evidentiy distinet in that the male genitalin are bihanate with the 
inner branch large and very deeply bifid, the divisions pointed and slender.

Habilat: Bloomington, Indiana, collected by Bollman. A single specimen was found in vial No. 42, of the National Museum collection, along with material of the preceding species. It should be noted that none of the Indiann interial which we have examined is the same as that from the Fast, and that the two species here estallished are founded on material which Mr. Bollman determined as $T$. lunatum, so that it hecomes improbable that the last species is found in Indians. $\Lambda$ comparison will show that if Harger's descriptions and figures .camot be reconciled with our eastern specimens, still less is this probable in the case of the Indiana material.

Tlie geisitalix of this species show an evident approximation to the Zygonopus type, for the lateral hooks may be looked upon as homologous with the oviter tooth of $Z$. whitei, while the inner tooth of that species is repliced by the forcipate process. Our specimen did not show plumose processes, but was not in proper condition to warrant the supposition that they are alsent.

Trichopetalum Aavidum (Bollman).

Craspedosnma flatilum, Bollnan: Eutonmologica Ameriana. Vol. iv, p. 2 (April 1888).

l'late III, figure 50.

"Yellowish brown, feet and antenne lighter. Kobust, segments not constricted, lateral carince small, and hody strongrly resemblingr that of Camporles. Antenna longer than width of borly. Ocelli 12-14, distinct, arranged in a triangular patch and in 5 or 6 scries. Dorsil plates mither smonth, setigerous granules small, seta rather large. Male fect crassite, those of female slender."

"Length of holy $5.8 \mathrm{~mm}$; width .7 mim.

"Hab).-Okolona.

"This species strongly rescml)les a Compoder. In life the individluals are a dusky yellow. This descrintion is based upon a male and femalc."

In the National Museum collection is a small yellow female specimen with 26 segments purporting to be the type of this species. Supposing that it is one of the specimens mentioned hy Mr. Bollman it is clifllenlt to understund his reiterated statement of its strong resemblance to Cleirlogonn (Camporles). The size and habit are certainly that of Trichnpetalum, although the carins are somewhat less developed than in the other species known to us. The sides are striate and the clorsal surface areo- 
Iate as in T', album. That this is really a Trichopetnlum we are not confident, but judging from the exterior it is nearer to Trichopetalum than to the other genern. One of Mr. Bollman's specimens is mentioned as being a male, and it may be reasonably supposed that he would have recognizel and mentioned the conspicnons and characteristic ninth pair of legs." The eyes depart somewhat though not seriously, from the Trichopetalun type, for they have a third row of ocelli in addition to the lunate arrangement in two rows (fig. 50).

A further difference consists in the fact that the setre are smaller and arranged more nearly in a transverse line, even on the anterior segments.

Trichopetalum-(?) ocellatum- $-($ Paokard $)$ - - - $\ldots$

Polylesmus occllafus Packard: Am. Nat. XVII, 428 (1883).

Craspedosoma packardii Stuxberg: $\Lambda \mathrm{m}$. Nat. XIX, p. 400 (1885).

Craspedosoma ocellatum (i’nckard) Bollman: Bull. 46 U. S. Nat. Mruseum p. $120(1893)$.

Plite III, figures :30-3i).

"The boly is snall, wather short, somewhat spindle-sliaped, and unusually cylindrical. There are twenty-nine segments behind the head; the senta are provided with the usual prominent lateral riclges. There is a row of clorsal setce on each side of the modian line; the surface of the scutes is finely granulated. The silles (genie) of the heal are fnll and swollen, somewhat wider than the first scute but about as wide as the hody behind. Ocelli 12-13 in number, conspicuous and black. Antenna with joint 4 half as long as 3 , joint 5 remarkably thick, incrensing in thiekness to the eml, longer than joints 6 and 7 laken together. Joint 6 not quite as long as thick; joint 7 small, conical; broad at bise where it is nearly as thick as the 6th; the joints rather setose; there are two terminal flattened sense-sete on the tip of the screnth joint. The cud of the boly is molerately blunt, with four setie on ench side of the last scrment (anal valves). It is of a pale horn color. I.ength $4 \mathrm{~mm}$.

"'This abermant form would not at first be regnrled as a L'olyolesmus, but would be ensily mistaken for a Trichopetalus. The individuals were mature or nearly 5o, as they were horn-brown. In the cylindrical borly and thick antenne it approaches Polydismus cavicoln Pack., from a mie on the shores of the Great Salt Lake. It differs from that species, which is cyeles, in the fusiform boly, much thicker antenue, and the fincr granulations as well as the larger number of segments."

The ahoye is Dr. Packard's original description. The species seems to have been placed in P'olydesmus becanse of carina larger than those of Trichopetalum, and the granulations of the dorsal surface. From the number of segments, shape of antennx, size, 
and other charncters, it seems that the present species is more related to Trichopetalum than to auy other genus described in this paper. It is possible that a closer study will show that it is the type of a new genus.

In using Dr. Packarl's description, the fact that he was comparing with species of Polydesmus should not be forgotten, and the "usual prominent lateral ridges" appear to be much larger than those of ally American craspedosomatid known to us. Dr. Packard also counted the anal valves as a segment, which is not customary.

That there is but one row of bristles on ench side of the median line, that there are but two olfactory cones, and that these are flatlened, are such anomalous characters that we hesitate to credit their-actual-oxistence-

'I'wo years after the original description was published, Dr. Packard printed in note he liad received from Dr. Anton Stuxherg, of Gothenburg, Sweden, relative to the "Generic position of Polydesmus ocellatus." The species is referred to the European genus Craspeclosoma on account of the general fact that this genus has eyes and thirty segments, Dr. Stuxberg having hal no opportunity of examining specimens.

$\Lambda$ change in the specific name is also proposed, on the following ground :

"In consequence of the necessity of ranging your species in another genus, all the nembers of which are provided with eyes, the specific name ocellalus should be removed and another introduced instead of it. I propose the name Craspedosoma packardii."

Distinctive specific names are of course desirable, but $n$ general application of Ih: Stuxberg's principle would necessitate too many changes to make possible its admission as a rule of nomenclature, hence the original nune is here retained.

Dr. Stuxberg also implies his belief that I). Packard's specimens were immature, being credited with but 28 segments (29 if the anal valves are counted), but we are convineed hat 28 is the normal number for 'Trichopetalum. Dr. Stuxberg's statement that immature specimens of Craspedosoma have 29 and 27 segments, does not agree with other buropen writers, according to whom the stnges are $26,28,30$. 
CONOTYLA gen. nov.

Eyes of numerous (16-19)* prominent ocelli arranged in triangular patches. Antennic long or very long, slender or sub)-clavate; third joint longest.

Mandibles with eleven pectinate lamella.

Promentum not distinct. *

Segments with molerately prominent, shoulder-like earina.

$\Lambda$ nterior male legs with ventral face of the last joint hispid with fine bayonet-like spines.

First two pairs of legs much smaller than tlic others; legs,+ 5 and 6 of males somewhat crassate.

Second legs of males with a cushion-like, cone-bearing process on the third joint; legs 4 and 5 with a similar process on the fourtl joint.

Mnle genitnlia of two distinet pairs, the posterior larger, attached to the bases of the ninth legr.

Ninth legs of male two-jointed, the distal joint oval, unarmed, without a chitinous knob.

Tenth and elerenth legs of male with large coxal apertures directed mesocandad.

Eleventh legs of male whth a meso-proximally directed process arising from the base of the thirrl joint.

Segments of adult 30 .

Distribution-Sortheastern North America.

In addition to the above, the following characters are common to all the species we have examined :-

Boily fusiform, brondest at ahout the 9th segment, narrowerl abruptly cephalad, and very gradually coudal; in cross-section nenily circular, with rather prominent lateral elevations.

Labrum with the lateral teeth exceeding the midlle one, but not projecting as far as the sides of the labrum.

Antenna with average ratio of length of joints 2.5:4.5:7-8.5: 7: 10:5:1.5.

Antepenultimate segment without carine, that is, the surface loctween the bristle-bearing tubercles is not elevated.

Penultimate with its ventral portion nearly covered by the preceding segment.

Anal segment with two long transparent papillec on the posterior truneation; from ench papilla springs a long slender bristle.

The genitalia of the species of this genus are, as far as known, double, that is consist of two entirely distinct pairs of structures (e. g., plate IV, fig. 73), and in this respect offer a sharp distinction from those of $\mathrm{Zy}$ yonopus and Trichopetalum, the nearest

* The ocelli number 24, and a promentum is present in Conolyla lcilergi 8p. n., which is provisionally placel in the present genus, with which it apparently has most aftinity. Males are not known. 
generic relntives. We have little fnith in the homologies of these structures suggested by European writers, for though in some special 'cases they may sometimes appear reasonnble, a general application is not evident. 'In dissecting $C$. fischeri we found that the posterior pair of genital processes always remainel attached to the ninth pair of legs, while the anterior pair remained in the body, and on accomt of their small size were at first overlooked. An examination of other species showed in each the two pairs of structures, though the anterior is much reduced, and perluips func. tionless. 'I'he posterior pair of genitalia may perbajss be homologous to the larger of the plumose processes of Trichopetalm.

T'his genus much resembles in charneters of form, carina and spines the three genern Zygonopus, Scoterpes and Trichopetalum.

- From the first tivo of these it is distinct in the possession of welldeveloped eyes, and from the last in having 30 segments.

The spines of the pectinate lamellie are sometimes bifid at the tip, especially in the mirldle rows.

In this genus the bayonet-like spines of the last joint are found on all or nenrly all the male legs, becoming fewer and smaller on the posterior legs.

In describing the species of this genus we have male frequent comparisons with Conotyla fischeri, the type of the genus, a new species of which we have abundant material and nre hence able to describe more thoroughly than the other species.

\section{Conotyla fischeri sp. $n$.}

Plates IV-V, figures isi-78.

Fyes.prominent, brondly tringyllar, the neclli armaged in four rows, $2 \cdot 4$ - 4 $+61.7=19$, the short rows being towarls the antennic. The dircetion of the rows is olligue to the proterior margin of the vertex, and diverging mesul.

Antenna filiform, 2.8 to $3.2 \mathrm{~mm}$. Jong, .14 to $.16 \mathrm{~mm}$. thick; approximate ratio of lengths of joints heriming with the seventh, 2.5: 4: $8:$ : $: 10: 5: 1.5$.

First segment viewed from ahove semicircular-reniform; a fine vidloge, or rather row of minute, bend-like protuberances; a small plane or slightly depressed area on each site of the meelian line near the centre of the surface of the segment; on ench sile the customary three bristles and acconipanying peminineness, the outer and larper bristle leing usually direeted horizontally ontwarl ancl locaterl on the susall carina or lateral corner of the segement. Second bristle mucl smally', located a little mesad and cophalad of the other, near the margin of the serment; thirrl bristle alout midway hetwen the seeond and the needian line, ind directly incsal from the first bristle. 
Mentum semi-elliptical, alout twice as broad as long. It is difficult to determine the posterior elge, as the chitin is gindually thimer, passing into a trunsparent membrane. $A$ cross-section, however, shows that the clitinized membrane extends bick to a transverse rilge and furrow, giving the nentum the proportions assignel above.

Promentum olssolete, the pninted triangular space between the rounded anterior elge of the mentum and the lingual lamine is covercel by a transparent membrane, sometimes appearing chitinized, but not to the same extent as the surrounding parts.

Stipes of guathochilarium with two cardos, an exterior, subtriangular, and a larger interior, sharply serrated along its anterior edge (see plate). Including the processes, the stipes are five times as long as thcir greatest width, which accurs anteriorly; spansely hirsute posteriorly with short briskles; $n$ row of longer bristles along the lateral maryin anteriorly; one long bristle alont the middle, considernloly removed from the anterior margin. Exterior process

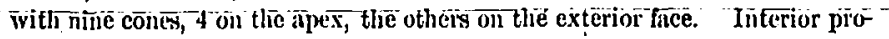
cess thicker than the exterior, with 12-10 cones, all on the apex.

Lingual lamine about three times as long as broad, the anterior and posterior elges nearly stiaight, converging mesnd; a few (7-8) scatterel bristles, a very long one near the anterior-exterior conel. Iingual lobes semicircular, suberiul to base of inner proces; with $4-i$ cones, the inner of which is larger, longer, sharp-pointel and curved mesnl.

Midclle lobe of tonguc sulsecual to the lingual lanine, equal in with to inuer process; anterior elges straight, meeting at a right angle, or rounded.

I.ingual process longer than broal; midcle tooth large, one or both of the - small lateral teeth frejuently olssolete.

Second serment about half as long as the first, the two onter bristles locited on the upper side of the carini, the second nearly directly ecpholud from the first. the thirl alout midway between the first and the median line.

Thirl and sulsequent segments gradually longer, aud with larger, gomewhat oblique, carine, on which the two outer bristles are locaterl. The third bristle is gradually furtlier away from the median line on the succecling segr-: ments, and directed more oblituely hackward. 'The anterior subsegments have about five tmusterse parallel lines comnected by fine longitulinal lines. . Begrimning at the middle of the first segment, and extending caudad over all the segments except the anal, is a finc median ridge, with a fine furrow on each sirle. Near the ventral elge of cich segment, leerinning with the seremel, is a thin oblique carina, nearly parallel to the thickened ventral margin, so that its posterior end is highler; this carina ling a downward curve or angle on the anterior segments, nucl is straighter on the posterior.

Posterior segments linve the eurine grulually smaller, and the midlle pair of bristims come closer to the metinn line. The surface of all the segments is finely ureolate; on the lateral and ventral surfaces are finc parallel furrows suggresting the striated condition in Iuliclac. P'osterior miclle portion of the segment freguently with a few obligue wrinkles or depreswions.

Antepronultimate segment shortest, without kecl, that is the surface be- 
tween the bristle-loaring protuberances is scarcely elevated, and the bristles are nearly in a traverse line.

Penultimate segment almost corered by the precelling; bristles in a straight row; posterior margin very finely serrate, as is also that of the precellingr segments, lunt to a less degree.

Anal sement truncate posteriorly, slightly emarginate in the middle, latcrally bronlly simute. There are eight bristles, two clone to the melian line, near the midlle of the serment, the others close to the posterior margin; at the emargination, one on each side of the median line, n pair of rery slemier bristles with large conic bases as long as the anterior pair of hristles; one bristhe at each angle of the truncation; below these a third pair in the upper-part of the simuation. All the bristles of this segment ate more slender than those of the preceling segments.

Anal valves subequal to the anal segment, alove with a blunt mole, convex; a slight ridge near the somewhat faintly raised margins bears three slendèr bristless at equal distances front each-other;-the-superior bristle is much closer to the anal segment than the inferior one is to the prenual seale.

Prennal senle semicircular, faintly truncate or nedianly emarginate, baring on enclı sille, not far from the median line a setigerous tubercle; the bristles very slenter, nearly twice as long as those of the ant valves, directed posteriorly and upward, lying close to the unal valves.

First peir of legs of male small, six-jointel, the joints beyond the coxic measuring respectively $.08, .34, .18, .12$, and $.42 \mathrm{~mm}$, third and fourth joints widest, $.12 \mathrm{~mm}$; no rougheningy or protuberances; claw large, with two large sccomdary claws on the superion elye.

Seconk pair of legs of male also six-jointed, larger than first pair, mensurements of correspondling joints, .10, .40, .18, .12 aud .4t mum.; second joint thickest, .14 mm., not including a inge roumied protuberance near the midIlle of the inferior surface of the joint. The dinineter of this protuberance is about half that of the joint, and its surfice is covered with transpatent chitinous cones of various sizes. ('law as for the first legs.

Third pair of legs of malc seven-jointed, lengths of joints, from coxa, .20, $.04, .34, .46, .16, .12, .18 \mathrm{~mm}$; width of thiril joint $.22 \mathrm{~mm}$. The inferior surface of the distal half of the serenth joint is covered with hook-like, transfarent processes arranged in Inngitulinal rows. ('law without eritlent secondary claws.

Fourth pair of Jers of male with joints measuring .20, .04, .31, .54, .20, .14 and .46 mm., width of thime and fourth joints .24 mm. Ahout oncthirl of the distance from the distal end of the fourth joint a large subclavate protuberance alout as broal as long, the surface covered with conce like the jrotuherance of the second leg. 'The serenth joint is rongliened like that of the third legr. So secondury claws.

Fith legs of male; joiats .14, .04, .10, .52, .18, .14 and .54 mm, third joint D. $\mathrm{mm}$. wille. A lange protulerunce similar to that of the lourth legs. Xo sccondary claws.

Sixth legs same as tifth in proportion of joints, etc. Third joint similar to second joint of seconil leg. 


\section{The Craspedosomatidx of North America.}

Seventh legs of male with joints of similar proportions; on the side of the proximal ent of the fourth joint a long, mearly cylindrieal process, at the end with four large terth, between which its surface is besct with small cones. The distal end of the coxa has a rounded protuberance covered with small knobs. 'This protuberance is on the inferior-posterior surface of the coxa, and it appears to fit against the anterior of the two pairs of genitalia.

Tenth legs of male with nearly the sume proportions as the seventh, slightly more slender, coxie closely approximate, ench prolucell into a protubernuce next to the median line; the protuberance is distally of soft tissuc, and very irregular in slıape and size. Seventh joint roughened below with hooks. Claw with two small secondary claws on supcrior edge.

Eleventh legs of male with similar proportions; third joint inferiorly and proximally with a cylindrical process directed mest. Seventh joint with look-like ronghenings more confinel to distal portion; two secondary claw's.

T'welfth legs of male slightly longer and more slender thm the others. Ser-

-. :-enth-joint as fonr elcienth legs. Two secondary claws; inferior surface of coxa vith sniall knols.

The legs of females are in a yeneral way similar in size and shape to those of males, but the anterior are more slender, aul all are destitute of the freculiar knobs, processes, and protulerances.

The normal legs of the borly are more slender than the anterior pairs. The bayonet-like structures of the seventh joint grilually decrease in number, and disappear at the forty-fifth pair. The surface of the coxic of all the legs is roughened with small cunical knols, as is also the surfuce of the pediferous laminie.

In the inferior groove of the claw of all the legs of this species is a very delicate hair extending consideribly heyond the claw, to which it lies closely appressed. We have not been able to tind any similar structure in other species.

Color olscure horn-brown, with dark brown points, especially on the exposed posterior portions of the segments; ventral portions mottled. I'roximal joints of lergs paler, the distul dark brown; antemue fuscous. P'enultimate segment pale, the last segment lark.

Length of large specimen $18 \mathrm{~mm}$; width $1.6 \mathrm{~mm}$.

Habilal-Central New York. We have collected about 100 specimens from the following localities:-Syracuse, Jamesville, Onativia and Marcellus, Onondaga county; Wolcott, Wayne county; Furmington, Ontario county. At Marcellus several in-. dividuals were found under the loose bark of a fallen butternut tree (Juglans cinerea). All the other specimens were found among leaves and rotting vegetable matter in moist woods.

It gives us great pleasurc to nane this species for our friend, Prof. J. T. Fisclier, of Syrnense University, whose keen powers of vision and lively company coutributed greatly to the success and pleasure of many collecting expeditions in central New York. 
Conotyla atrolineata (Bollm.).

Craspctosoma atrolincatum Bollman: Proc. U. S. Ynt. Mus. X, p. 618 (1887); Bulletin 46 C. S. Nat. Ifuseum, 1p. 35 and 183 (1883).

l'ante VI, figrures $95-100$.

Eyes rounded triangular in shape, the ocelli in dingonal rows leeginning posteriorly $7+6-6+4+3=20$, or $7+-6-1+4+2=2=10$.

Antenna filitorm; $2.5 \mathrm{~mm}$. Iong, .1.4 thick, ratio of lengtlis of joints beginning with the seventh, 3: 4.5: 8: 7.5: $10: 5.5: 1.5$, the seventh being proportionally longer than in other species of the genus. The antenne are somewhat stonter than in fixcheri and limllnami, cf. tigs. 6.t, 8.3 and 9i).

Gnathochilarium apparently not different from C. jischeri, except that the lingual processes are strongly tridentate.

First segment reniform; anterior margin and setigerous tubercles as in C. fischeri.

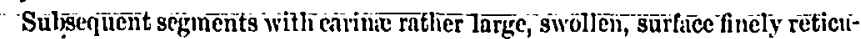
lated, anterior subsegment with about three transverse parallel ridges, sometimes concealed by the preceding segment: Between the anterior and josterior subsegments there sometimes appears a row of small, bual-like rilgres.

- Anal segment smooth, the posterior scarcely or not at all depressetl. The two anterior setae very close together, the others as in $C$. fivetevi.

Anal valves slightly convex, the posterior margins neally straight up to the angulation which is quite sharp ant equakl to the anal segment.

l'reanal scale ns in C. jischmi.

Male genitalin of the anterior pair with (fig. 9i) a large bulbous leise, bifid distrilly, the larger division Incininte-dentate at apex. The posterior pair of genitalia (fig. 96 ) are much more complex than in bollwani or fischeri.

Color light horn-brown, the carine und an rather broat dorsal line darker, Bometimes very dark.

Length $14 \mathrm{~mm}$; width $1.3 \mathrm{~mm}$.

We have examined nine specimens referred to this species. One mature male and two fumales. T. S. N. M. No. 439 , from Glacier, B. C.; five immature specimens U. S. N. M. 33:3, from the same place, and one female from Winona, Minuesota (No. 331).

The type of this species was from Glacier, 3 . C., and we have cxamined specimens from that locality. Mr. Bollman also reported this species from Winona, Minn. (Coll. Holyinger). The single female specimen is now in the National Museum. It loas three dark longitudimal lines, but the color is lighter than the typical specimen, the animal considerably more robust, less attenuate posteriorly. The arrangement of the ocelli is also different in specimens from the troo locilities, cf. figs. 99 and 100.

We would not be surprised if when the males are collected the species will prove to be distinct. The great difference in habitat 
also indicates probable distinctness, for with the possible exception of Underwoodia inloides (Harger) there is no chordeumid species known from localities so widely sepurated.

\section{Conotyla bollmani (MeNeill).}

Trichopetulum Lollmani IIcXeill: I'roc. I. S. Xat. Museum X, 330 (1837); 13ull. Brookville Soc. III, 8 (1988).

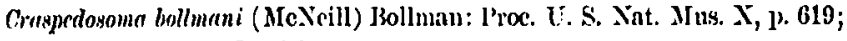
Bull. 46 L. S. Nat. Mus., p. :36.

Senteryes bollmani (Mc.Neill) Jollman: Proc. I.. S. Nat. Mus. XI, 405, 1888; Bull. 46 U. S. Ynt. Mus., 106.

['late $V$, tigures 79-9)4.

Fyes triangular of alout-19 ocelli, arranged in-four rows, as in $C$. fischeri, 2 : $4-7-7$, though this formulu is varich by the interposition of small ocelli, and the curving of the rows.

Antenn: filiform, $3.5 \mathrm{~mm}$. long, .16 mm. thick; ratio of Iengths of joints berinning with the seventh, 2.5: 4.5: $8:-7.5: 10: 4.5: 1$.

(inathochilarium as in $C$, fixcheri.

First segment semicireular or subreniform; about half way from the melian line to the lateral angle is a well-pronounced iepression about the size of the Inse of an antenua; the midkle tubercle is also situated in a smaller, moro shallow depression. Tuhercles uranged as in $C$. fixcheri. Surface nearly smooth, a very fine metian furrow berrinning abont the midlle of the segment, and extending to the pesterior margin. Anterior margin raised.

Subsequent segments nearly the same as in C. fuchcri. The ridge of the clorsal furrow is someswhat friuter, and the oblique wrinkles of the posterior portion of the sergment do not appear. Soreover the whole dorsal surface of the segments is very minutely hispid with microscopic point-like bristles, either not present or seare in C. fixcheri. I'osterior set:c as long as the segments.

Anal segment without median furrow or ridge, truncate behind for a distance of alout half the bieadth of the scyment, the eight setec arranged as in C. fischeri, except that the outside pair are farther away from those alove them than in that species. Sirfuce more finely areslate punctate than the other segments and with the mieroscopic point-like hairs.

Anal valves not strongly convex, more prominent alove the middle, and almost amrulate, with three sotigrerous tubercles along the margin somewhat. more prominent than in $C$ fischeri. 'The surface of the valves is like that of lie anil serment.

Preanal seale as in C. fixcheri.

Color uniform lighte hom-lnown.

Length $17 \mathrm{~mm}$; willth $1.7 \mathrm{~mm}$.

Inhitut: Caves netr Bloomington, Indiana. We have ex:unined about to specimens, as follows: Bloomington U. S. 
N. M. No. 3; Truitt's Cave, No. 234; Neal's Cave, No. 235; Coon's Cave, Nos. 236 and 443 ; nlso Nos. $\$ 19$ and 44 , with no locality given. MeNeill's types were from Mayfield's Cave, five miles nortliwest of Blnomington. The species is reported by Bollman from all the above localities and from Phitt's and Donehue's Caves, Bedford, Indiana, and said to be abundant.

\section{Conotyla leibergi spl. n.}

I'late VI, tigures $10: 2-104$.

Eyes subtriangnlar, the posterior dorwil side straight, other sides curved, beginning at posterior (lorsal sicle arranger $9: 6+5 ; 3: 1=2 \cdot 4$, the fint row - with two sminll ocelli.;

Antenna sulsclavate, length $1.7 \mathrm{~mm}$, fitl joint thickest, . 16 mu. in diam-

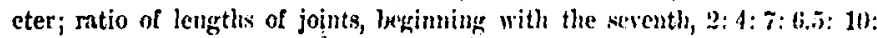
: 5:5.

Gunthochilarium differing from that of the threc precerling species in the possession of a small, broully triangrular promentum.

First segment anteriorly nearly semicircular, posteriorly slightly emarginate, margined anteriorly to the laternl angles; a fine dowal line postcriorly; the three tulsercles located as in $C$. fixcheri.

Subseguent segments with gmalually swollen caringe of moderate size, proportionaly not so large and abruptly elcrated as in C. fischwi. 'lhe lines and reticulations as in that species, but more pronounced.

Anal segment broully trinente, more so than in C. fixchiti. Bristles arranged as in that species.

Anal valves subegual to aunl segment, the angle more pronousueel than in C. fischeri; molerately convex, mirgined, with three bristles, anranged as in C. fixcheri.

- Anal scule small, marly semicireuhar; two tubercles, with iong sote alppressed to the anul valies.

Color: Jomsum tark fuseous-brown, nearly black, a dine median linc, a line aloug the tubercles, the ventral portions, fect and extrenitics of the inoly paler, horn-lorown or sordiul. Autentnic dark lrown. On some paler speciuens the larker color of the posterior sulswhine'nts gives the apjearance of a series of transverse diurk lyunls and a row of dark spots alonge the sides.

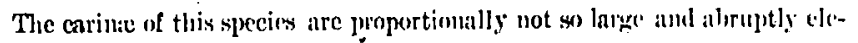
vated as in C. fischeri.

I.cogth $14 \mathrm{~mm}$.; width $1.1 \mathrm{nmm}$.

Ifabilal: Isake Pend d'Oreille, Idaho.

We have examined three fentale specimens collected on "dry granite lediges, in tufts of moss." 'lhe material was sent us by Mr. J. B. Leiberg, for whom we take pletsure in naming this species. 
We attempted to identify this species with Trichopetalum glomeralum Harger, but the differences in color, size and number of ocelli are too great to permit this.

The characters of the antenna, gnathochilarium and ocelli render this species quite distinct from atrolineata. Indeed, it is probable that when the males are found this species will prove generically distinct from Conotyla.

\section{Conotyla glomerata (Ilarger).}

Trichnpelalmm glomeratum Harger: All. Journ. Sci. and Arts, IV, pp. 118 (1872).

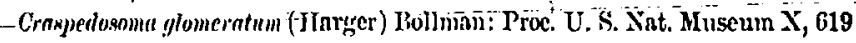
(1887); Bull. 46 L. S. Nat. YIus. pp. 36 and 120.

l'late VI, figure 10).la.

"This species is somewhat larger than the preceling (lunatum), but closely resembles it, except in the following points: The general color is somewhat darkcr. The cyes of 10 ocelli in a subtriangular patch. There are 31 segmente, and the fith joint of the antenna is much shorter than the third. These joints, except the first, measure: second . 20 mun.; thirl .40 min.; fourth $.24 \mathrm{mn}$.; fifth $.33 \mathrm{~mm}$.; sixth $.18 \mathrm{~mm}$.; seventh $.12 \mathrm{~mm}$. Length of animal $10 \mathrm{~mm}$.

" $\Lambda$ singre specimen of this species was collectel by the writer in the valley of the John Day River, Oregon, in October, 1871."

The original description of this species is so brief that the generic position must remain in doubt. $\Lambda$ general resemblance to Trichopetulum lunatum is alleged, but the thirty(-one) segments, the shorter fifth joint of the antenna and the triangular eyes show at close approximation with Conotyla.

\section{Conotyla wyandotte (Bollnan).}

Scotherpes mymulte Bollman: Proc. U. S. Nat. MLuseum XI, p. 405 (1888). Bull. 46 U. S. Nat. Museum p. 106 (1893).

Plate VI, figure 101.

"Ditumosis: lelated to ('r. lummlum (Harger), but the color dark, ocelli arranged in a triangrular patel, and the boily larger and morc robust.

Ilubitat: Wyandotte, Indiana.

Jinc: T.S. Satiomal Muscum.

Drscriplion: IBoxly stout, sliort, scarcely depressel. Dorsal plates retioulated; lateral carine as in lunatum. Ocelli 16-4, in a triangular patch. Yellowish-brown; legs palc. J.ength $.10 \mathrm{~mm} . ;$ width, $1.5 \mathrm{~mm}$.

This new species is describel from a female which was found a few miles north of Wyaulotte Cave, Crawfort County [Indiana]." 
'The triangular"cyes, dark color and larger size indicate that this species has more characters in common with Conotyla than witls Trichoperalim, thongh when males are found it is likely to prove distinct from both genern.

We examined the type specimen, U. S. Nat. Museum Yo. 440, and made the following notes :-

Lyes (fig. 101) triangular, the ocelli in diagonal rows betrinning posteriorly $1+6+5+3+1=16$. Three ocelli horler on the lateral maryin of the head.

First segment with posterior margin convex, otherwise ns in $C$. fikcheri.

Subsequent segments with the mediun bristles longer than the exterior ones, at least on posterior segments. The tulkercle on which the interior. bristle is located is just mesal of the much swollen carina. An elevatel rilge runs above both the cxterior tuliercles. Segrments of the midille of the lookly short, bristles ratlier close together, the median pair located well nheal. Anterior subsegments with four or five rows of small, oblong elevations set close together. The usual median furrows and rilge present, but faint. On the posterior segments the carina gradually disippear, and the protuberances tend to become arrmuget in as straight line.

Penultimnte segment equal in length to the antepenultinate.

A nal segment contricted posteriorly, vieweil from above it appears squarely truncate. The usual cighlt bristles present.

$\Lambda$ nal valves not prominent, margins scarcely raiscl; aloove slightly exceeding last segment, and fainitly angled; ench with three bristies, the superior one close to the apex of the anal segment.

In September 1893 two female specimens of a species bearing a general resemblince to wyandotle were collected in a swampy pasture at Grass Lake, near Jackson, Michigan.

Habilat: Known only from the vicinity of Bloomington, Indiann.

\section{UNDER WOODIA gen. nov.}

Eyes moderately ierclopel, of nimerous (13) ocelli arranged in triangular jastches.

Antenna moderately rolust, subelavate, third joint longest, or the fifth suberiual.

Mandibles with eight peetinate lamellic.

Promentum present, triangrular.

Segments with lateril catrine strizeform, nppearing only on the anterior segments; setigerous tubercles minute.

Lcegs rather robust; terninal joints of mitle legs not hispicl.

First pair of legrs of male rohust.

Second legs of malc strongly crassate, the coxac produced, Ihamate; claw very Bnall. 
Third legs of male modemtely crussnte; coxie proluced, third joint nuch swollen.

I.egrs 4-7 not specially moditiel.

Genitalia of male of two pairs of lamina, the anterior broad, the posterior slenker.

Ninth lers of male two-jointed; lasal joint bulbous, attenuate above; second joint bronlly oval.

Tonth legs with coxa much enlargetl, the other joints reducerl.

Segments of alult 30 .

Distribution: Northenstern North A merica.

This genus is named for Dr. L. M. Underwood, to whose hindness-wc-are-indebted for the opportmnity of studying Myriapoda.

The following new species is male the type of the genus because the male is known, and the generic secondary sexual characters are drawn from this species. In the other characters the two species agree, except in the proportions of the antennal joints.

$A$ notewortly fact regarding this genus is the enormous preponderance of females. We have collected nearly 300 specimens, of which but two are males. In most Diplopoda the females are more numerous than the males, but such a proportion as this is not reached elsewhere, as far as we are aware. The other genera of Craspedosomatidie do not seem to have the sexes especially unequal in number.

\title{
Cnderwoodia polygama sp. $n$.
}

\author{
Plate $X$, fignres 180-190.
}

Borly fusiform, broadest abont the iniddle, marrowed irradually to inth ends.

Vertex prominent, smontl and slining, without evident sulcus.

Clypeus spansely lirsute below; evenly convex.

Eyes loratly triangular, of 13 ocelli arranged in threc rows $6+5$. The extermal ocellus of the upper rows is somewhat alove the line of those with which it is counted.

Antenuic molcritely robust, slightly clavate; the approximate ratios of lengtlss of joints, beginning with the seventh: $3: 4.5: 9: 5: 10: 5: 3$. Joints all hirsute, the distal more than the proximal.

IIentum rounderl in front and lechind.

lromentum triangular, the posterior side conave.

Stipes and lingual lamina with a few long hairs.

lingual lobes with three sense-conew.

Styliform processes decply trifid, the middle tooth smallest.

First segment broudly reniform; the posterior corners rather square; not medianly cmarginate behiml. Outer setigerous tubercles somewhat mesud 
from the posterior cormer; second tabercle about midway between the first and thircl; the third nather close to the medinn line. 'Tubercles very smull, located in very slight depressions; the setec slender and if horizontal would nearly reach the posterior maryin of the segment.

Surfuce of all the segments apparently smonth and shining, but if sufliciently magnitied it appears finely reticulate-nreolate, the areas being irregularly hexagonal or qualmate. On the anterior subsements the areolation is somewhat coarser and more regular; consisting of rectangles in transverse rows. On the sicles of the segments and helow the longitudinal lines of the reticulations become more distinct giving the apjearance of longitudinal striations. The usunl fine median line distinct.

Carina very line, linear, strieform, ollique, the anterior end heing higher; -.the carina-gralually decrease iti size from the first schment and dianpenr about the tenth. Below, near to and parallel with the ventaal edge of the segments is a fime furrow, more eviklent on posterior segments.

Setigerous tubercles and setro alwo lecreasing in size from the first segntent, almort disappearing on the middle segments. On posterior segments the trubercles and set:c incrense in size, extending beyond the posterior margins of their segments.

Iosterior segments not much shorter than the anterior.

Amal segment without median line; brondly trunate; the domsal pair of tubercles very small and close togcther, located in a very slighth trunsverse furrow, the seta not reaching the josterior margin of the serment. The conic processes of the posterior margin as long as the distance from their basas to the anterior pair of tubercles; from their apices extend yery slender hairs (frequently broken off) equalling in length the conic bascs. The next pair of marginal setie located near the corners of the truncation, and as long as the conic processes.

Anal valves smosth or with faint rertical wrinkles; three setigerous tubercles somewhat removed from the slightly compressel margin.

l'reanal sale semicircular, bratdly emarginate; two tubercles and slender scta'.

Pedigerous lamine plain in front, seticulate-areolate, mucronate between the bases of the legs.

Legs of both sexes rather robust.

First legrs of male (fig. 180) six-jointed, rather robust; lasal joint with apex hirsute with fine hairs; second joint bronder than long; last joint with a comb of conser hairs along the rentral side; claw large; two supplementary claws.

Sccond legs of male (tirr. 181) six-jainted, strongly crassite; hasal joint produced into a long chitinots hook; second joint very small; joints 3-6 very stout and hirsute with fine flexuous lanirs; last joint densely clothed with long flexuous hairs, rspecially long at apex, and far exceeding the very small claw.

Third legs of inale (fig. 1-2) seven-jointed; bisal joint produced into rouncled processes with a tuft of tlexuous hairs at apex; second joint very small, concenled (in the drawing) belind the first and third joints; third joint

AnNalos N. Y. ACA1. Sct., IX, Nov.', 1995-'; 
strongly erassate; fourth joint less crasente, the others nearly normal, except that all are hirsute; claw very small, but lunger thin on the second legs.

Legs 4-7 not specially modified.

Male genitalia (figs. 186-187) consisting of an anterior Inmina deeply bifid at apex, the divisions subequal, cursed hackward; anterior lamina simple, narrow, subecual in length to the other; a median sulkclarate process arising from the peligerous Iamina.

Ninth legs of mule (figs. 18t-187) two jointed, the basil joint large and bulbous at lense, gradually attenuate clistad into a point, subequal to the genitalia in length; second joint broadly oval, attached by a narrow lase to the outer side of the first juint; outer face of second joint somewhat flattened,

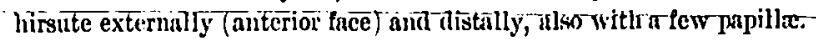

'Tenth leass of male with the coxa (fig. 185) greatly enlargel and with an irregular mass of membrane or hardencl secretion attached to the ventral sicle; other joints normal lut reduced in size.

Color dark horn-brown, lighter below. The shade varies, some specimens being much lighter than otliess. The darkest color is upon the head and the exposed portion of the anterior subsegments, giving the animal alternate bands of darker and lighter brown, if examined more closely. Last segment and anal valves dark. Lxcepting the dark band the segnents are spotterloand mottled with light brown or whitish. $\Lambda$ tine median line pale or whitish. Feet palc, the distal joints darker than the proximal. Antenue dark, each joint tinely ringel with white at base.

Length about 8 min.; wilth . $65 \mathrm{jmm}$.

Ilabitat: We have collected about 80 specimens on the north slore of Long Island, New York, May, 1893, at two stations about seven miles apart, Centreport and Cold Spring.

'The habitat was in both cases quite the same, among rotting leaves on a heavily wooded hillside where the ground was springy and moist all the year. The Cold Spring station is near the building of the New York State Fish Commission. Of the nearly 80 specimens but two were males, henee the specifie name. Specimens were not abundant and several hours were spent collecting them, in the hope of finding more males, so that the material for study might be more abundant, the animal being so small that nothing can be made out with accuracy withont disscction.

The species differs from $U$. iuloides in being slightly larger, of dark color, in the better development of the eves, and in having the third joint of the antennse longer than the fifth. 


\section{Underwoodia iuloides (Harger).}

Trichopetalum iuloides Iarurel: Am. Journ. Sci, and Arts, IV, 11\% (1872); layder: Proc. li. s. Nat. Mlus. III, 527 1881; Packard: Proc. Au. I'hilos. Soc. XXI, 192 (1883).

Chordeuma iuloides (Harger) Bollman: Bnill. 46 U. S. Sat. ILus. 121 (1893). Plnte $\mathrm{X}$, figures 177-179.

lyes more or less triangular, of about 13 ocelli, without cvident arrangement into rows.

Antenna molentely clavate .7is to $.85 \mathrm{~mm}$. long, fifth joint thick $(x), 10$ to -12 mm- in diameter matio of lengths of joints, beginining with the seventh, 3: 4.5: 8-10:5.5: 10:5: 3. Olfactory cones very slender and sharp-pointed.

First segment smooth, nearly semi-circular in front, struight behint, except a.slight emargination in the nilldle; with a very fine raised margin anterionly to the lateral angles. 'Median furrow indistinet. 'Three finc, hair-like sete on eacls sille, one close to the laternl angle, one a short listance from tho median line and one miclwa between.

Subserjuent segments nearly smooth, a very fine dorsal line, the lirst five or six serments witl a slight trace of lateral carine, the others smooth, as in Iulidx. Fach segment his thrce sulall bristles on each side, situated as on the first segment. On posterior sements the bristles become lnger, have is prontinent lase, and are closer to the posterior margin of the segment. The ventral elges of anterior scgmenty, at least, are sinarply and finely scrmte.

Amal segment smooth, as viewed from above having a semi-circulnr outline, posteriorly truncite. From the pasterior margin of the trumention, near the mieldle, come two long conic ponillic, cach tipped with a very slender flexuous hair. At each corner of the trumbation, a little remosed from the margin is a slender bristle directed backwarl; another posteriorly-directed slender bristle some distauce below, near the simuation. The other two dorsal bristles are near the median line, some distance behind the middle of the segment, and ench located in a depression.

Color light horn-brown, mottled with white, many specimens show very little brown and arc dirty white in color, especially in alcoliol. The boly is so transparent that the contents of the alimentiry canal frequently wive the appearance of a dark dorsil stripe.

L.ength $6.5-8 \mathrm{~mm}$.; willth .6 mm.

Halitat: North Eastern North America. Harger's type was from Simmons' Harbor, north shore of Lake Superior. We have collected specimens at Orillia, Ontario; abundant on Chief Island, Iake Couchiching; Grass Lake, near Jackson, Michigan ; and at several localities in central New York; Syracuse, Kirkville, Marcellus. A careful search is likely to be successful in any wooded locality which is so situated as to soil and drainage as to be always moist, without being submerged. Individuals are 
however, seldom abundant, and we have spent considernlle time in collecting about 200 . None of these are males, so that the generic position of the species must remain somewhat in doubt. We were very mwilling to believe that so lnige a number of specimens were all females, and reexnmined them several times; finally, in order to make sure that the internal structure corresponded with the external appenrance, longitudinal sections of about 30 were eut, all of which showed more or less developed eggs. We had begun to suspect parthenogenesis or some other reproductiva-arrangement novel ir-Diplopoda whentle specitinens of $U$. polygama were collected. Males were in that case found, but with a disproportion of sexes so great as to encourage the hope that the males of illoides will be discovered by persistent collecting.

Some specimens of this species have the fifth joint of the antenne equal to the third, in character otherwise found only in Trichopetalum. The length, however, is not entirely the same in specimens from the different localities.

\section{CASEXA gen. nov}

Eyes well developed, of numerous (23) ocelli, arkunged in subtriangular patches.

Antenux moderntely robust, clavate, third jning lomgest.

Mandibles with eleren pectinate lamellic.

Promentum present, tringular.

Segments cylindrical, without lateral carime, longitulinally striate; setigerous tubereles minnte.

I.egs slender; terminal joint of male legrs not hispid.

First legs of male small and slender.

Second legs of male very slender, the coxte producerl into a curved process; hird joint tuberculate on the ventral face; claw nomal.

Thirl legs of male not crassate; coxa producen, third joint not swollen.

Legs 4 and is not specinlly molified.

Sixth legrs with coxa somewhat enlargerl, nut with a tult of hairs.

Severith Iegs of mule with the coxa much culargerl, the other joints reduced.

Genitalia of male of two pairs of lamine, the anterior large, the posterior smaller, hoth pairs complex.

Ninth legs of male two-jointed, the lossal joint hroat at basc, pronluced distrud, second joint broadly oval.

Tenth legs of male with coxac mueh enlarged, the other joints reducel.

Segments of adult 30 .

Distribution: Californitt. 
'This genus is named for Captain Thomas I. Casey, to whom our thanks are due for $n$ collection of Californian Myriapoda including this and other interesting forms.

Caseya differs from Underwoodia in the more numerous ocelli and pectinate lamellie, the entire absence of carinie, the pronounced lateral stria, the slender anterior male legs, and the greatly enlarged coxe of the scventh legs of the male. Many other differences of the same or less importance might be enumerated, such as the shape of the modified coxa of the second and third pairs of-male legs; -the_slight modification of the coxa of the sixth male legs, the process of the coxic of the tenth leg $\bar{s}$, and the--..oblique carina of the coxne of the tenth and following legs; also the form of the male genitalia and ninth male legs, for these differences are not paralleled among the species of the other genera.

On the other hand there can be no donbt that these two gener: form a natural group and lonve more aftinity with the European genus Chordeumn than with the other Aneriean types.

The mandibulary cardo is apparently smaller and more coaleseed than in Cleidogona; no sulcus is evident, but an suture becomes apparent as the alcoliol dries out.

The body is somewhat more gradually tapering candad, and slightly less so cephalad than Cleidogona, which this form much resembles in external appenrance. The head is, howerer, not wider than the first segment, and the whole appearnece of the animal is the most iuliform of any of our Craspeciosomatidx. 'The entire absence of carine, the rudimentnly character of the setigerous tubercles, . Which are sunk in depressions, as though to more thoroughly dispose of thein, and the presence of longitudinal striations, also give foree to the fact that in the iuliform Craspedosomatidie we have nnother of the strange npproximations of external form between animals widely separated by the more important structural charncters.

\section{Caseya heteropus sp. 1 .}

Borly fusiform, hroalest alout the midrlle, narrowed gradually to both ends.

Vertex prominent, sncoth and shining; a few sattered princtations (prerhaps the inses of hair); proteriorly cmareinate-cxearate, with a short melinn suture extending foum the posterior margin and not reachingr an imarinary line comnecting the eyes. 
Clypeus sparsely hirsute below, rather plane, a transverse depression above the labrum.

Eyes brondly subtriangular, the occlli not amanged with much regularity, the vertical rows being usually more evident than the horizontal. Ocelli counted horizontally from above: $7+6+5+4+2=24$, or $6+5+4-3-3=21$, $1+6:-5+4:-3+2-1=22$.

Antennie moklerately robust, somewhat clavate, ratio of lengths of joints, beginning with the seventh: 2:4:8:6:10:6:2.

I'roximal joints spursely, the distal more densely hirsute. IBelow and laterad from the antemal socket the margin of the hend has a deep rounded notch.

Ifentum broadly quadrangular-arcuate, all the siules curved, convex in front, conçve behinit.

Promentum triangular, subequilateral, posteriorly broadly emarginute; spursely hirsute.

Stipes and lingual lamine sparsely hirsute.

Jingual lobes with five sense cones.

Styliform processes r quadridentate.

First segment broadly reniform, slightly enarginate in the midlle posteriorly. $A$ tine raised auterior margin; rorsal median line beginning just back of the midlle of serment; outer setigerous tubercles somewhat mesil from the onter coluers of the seyment; second tubercle about midway between the first amil thircl. 'lubercles minute, rather closer to the posterior margin than in Emerwoolia.

Surface of scgments appeariug smootl, but reticulate-arcolate as described for Underwodia pulyjama. On the sides and below the posterior subsegments are longitulinally strinte as in Iulide. On the first segment are no striations; the second with but one above the lower tulicicle; the thirl with two; the suceeding segments with three or four; below the lower tubercle about ten striations, very distinct, at equal distances, somewlat oblique, the posterior end lower. The suture between the subserments is wiunate medinnly, the anterior sulsegment extending somewhat into the posterior. Tubercles minute, located in depressions, on all secrments except the first and last arminged in a transverse line. No trace of lateral carince, the striations of the side not larger than those below. On posterion segments the striac lelow the tulsercles are somcwhat morc numerous. Cormers of the segments helow evenly rounded, the nungin somewhat thickenet; the lower side of the subnarginal furrow is extended into a minute sharp tootl.

last segment truncute, ttibereles loxated as usual; conic processes and setie not scen.

Anal ralves with the usunl tubercles and long setic.

Pruanal seale semicircular, sulbtruncite posteriorly; two long bristles somewhat remote from the posterior maigin and locited upon a transicrse thickenin's of the scale.

J'eliferons lamine very small, coarsely arcolite, subearinate in front, neuminute distal. 
Legs rather slender, molerately hirsute, the coxac approximate, reticulateareolate, especinlly on pasterior legs.

First legs of male (tiz. 198) slemler, appurently of the usual form, our specimen eomewhat broken and distal joint lost.

Second less of male (tigrs. 199-200) more slender than the first; coxa producel from the anterior face into a blunt process curved hackivari; the process is partly concealed ly a tuft of long hairs which arise from the coxa behind the process, extend distal and inesal and are curved around the process; third joint very long, thickly tuberculate on the middile of the ventral face.

Third legs of male (figs. 201-203) with coxa much enlarged and produced into conic processes, clothel at apex with a tuft of long hairs; botle surfaces of the joint are sparsely hirsute with shorter hairs; other joints not specially molified, except that the distal joints are more hirsute; claw normal, cqual to-that of the sccond legrs.

Sixth male legs (fig. 206 ) witlr coxa-slightly-enlarget, the mess)-distal (orner prominent, clothel with long hairs.

Serenth male legs (figs. 207-209) with coxa greatly enlargecl; on the midthe of the clistal sile a comic procesy truneate at apex and surmounted with a tuft of long luirs; in front of the process are other long lasirs, and awother tuft at the inner distal conner of this joint. The second joint inserted at the onter corner of the coxn. Other joints somewlat reduced in size, so that the length of the serenth lecrs does not exceel thiat of the sixth. The third joint is shortened more than the others.

Male genitalia complex, (tigss. 216-217) and as we had but one male, dissection was not carricul far enotyll to make phin the relations of the parts. The -posterior arm seems to be perforate, the anterior part of it extending up into the complicate anterior arm as two slender columns ( fig. 216).

Ninth legs of male ( hig. 218) withı basal juint prodtuced alowe and anglet near the apex with a deep, rounded notel subtended by a sharp tooth; second jnint narrower than in L"ulerwondia, hirsute distally and on the lateril face. The pedigerous Janina lins long curved ends aud is medianly prominent. It may be that this ineclial prominence is homolugrous with the lomg mediun process of Underwnolia.

T'enth lerg of male (figst. 210-211) with coxie much enlarged, similar to those of Underwoolia; on the posterior side near the iperture a large rounded prominence; also an oblifue carina; other joints eridently reduced.

Eleventh and twelfth Iegs of male (figs, 21?-213) slightly thicker than the normal (fir. :214). 'Thirl joint witl a few' small tulheredes on the ventral face; enxac oblingely carinate on the posterior face.

Color in alcohol, ditrk brown with a buith tinge. This may be due to the fact that the syecimens are old. Iulidac sometimes turn blue in alcohol. 'The

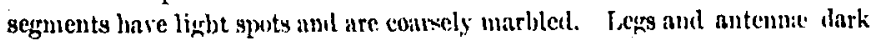
brown, especinlly the distal joints.

Length $15 \mathrm{~mm}$. ; wilth $1.7 \mathrm{~mm}$.

Exact locality not known, but the specimens, a mature male and female, are evidently from California. In the same bottle was a 
specimen of Preromopus which is known with certainty to have been taken on the hills back of Saucelito, across the Golden Gate from San Francisco.

\section{Notes on Fxomio Craspedosomatida.}

As likely to be of interest in connection with a study of the $\Lambda$ merican forms, we add brief notes on the other genern and species, as far as they have beell described sufnciently to state the more important characters.

RnISCOSOMA Latzel. 1884.

Myr. Usst. Ung. Mon. Zweite Mïllte, p. 173.

liyes distinct, ocelli numerons (11).

Antenne-moderntely-long,rather sleuder,_slightly clivate, fifth-joint-long.-....est.

Seguncuts alove strongly arched, with large, continuous carince which are decurved in the clirection of the dorsal arch; setigerous tulercles very stuall.

Distribution: Austro-Hungary.

This very curious genus was described from individuals supposed to be immature, with 23 segments, and measuring $3.5 \mathrm{~mm}$. by $6 \mathrm{~mm}$. The carine are so large as to reach down to the ground when the animal is crawling, so that the animal is hollowed out below. 'The resemblance to a Polyzonium is very great.

ATRACTOSOMA Fanzago, 187i.

Anmuario d. Soc. d. Naturaliste in Morlena X, p. 70.

Eyes distinct, of numerons ocelli (25-29) arranged in triangular or semicircular putches.

Antenne very long and slender, third joint longest.

Seguents with lateral carina large, horizontal, roumled in front, hookel behind; seta rather long.

Serenth segment nearly normal.

Fist two pairs of legs small and slender, the next five pairs strongly crissate in the male.

I.egs 3-7 of male with a very siont claw, the ventral face of the last joint hispid. Coxa of serentlı leg with a conic process. Genitalia of male complex, of threc pairs of lamellic.

Ninth legs of male simple, oblong (ct. Verheft).

Tenth and eleventh legs of male with a wart-like process on the coxa, the terminal joint somewhat hispicl.

'The ahove charncters are diawn from Latzel's description of A. meridionale Fanzago, the type species. 
Atractosoma carpathicum Iat:el.

Seventh segment of mule with the ventral margin prokincel into two long slender tecth.

Genitalia totally different from those of $A$. meridionale, of two pairs of lamells.

Ninth legs of male very simple, reduced to a somewhint conic process with iu apical liristle.

Atractosoma bohemicum lasicky.

Anterior male legs with the terminal joint not suslioned or hispid.

Nintl nalc legs simple, without proceswes or tecth, their sternum also simple.

The North American Craspeclosomaticla, as far as known, show no close resemblances with the species of $A$ tractosoma, either in form of body or structure of genitalia and ninth male legs.

CRASPEDOSOM A Lach and liawling, 181 .

'Truns. Jinn. Sac. XI. 2, p. 380.

Eyes well developed, of numerous ( $25-28)$ ocelli armnged in trinngular patches.

Anteune very long, slender, third joint longest.

Segments matier depressed, with traces of ohtuse curine, especially in front; tubercles and sctec very small.

Serentlı setgment ventmally in faterl.

First and secoml male legs sumall, the last joint fringed on the inner edge.

Jeess 3-7 of male sareely thicker than the normal, the last joint pulvinate.*

Male genitalia of two puirs of processes, the larger simple, broid, the others approximate, very sleucler.

Ninth legrs of male replaced by a jelviform structure with modian processes.

T'enth and eleventh malc less with a verruciform process.

Distribulion: Many species, reported from nearly all purts of Europe.

The above characters are drawn from Latzel's description and plates of $\mathrm{Cr}$. rawlinsii, the type of the genus. Numerous species linve been referred to Crasperlosoma, miny of them without proper study of the secondary sexunl characters, and without giving them such systematic weight as they seen to us to be entitled.

Among chnacters of this kind some of the inne notewortly are as follows :-

*Whether these legrs differ from those we have malled hispid is not elear. 


\section{Craspedosoma oribates Intzel.}

Genitalin apparently similar in plan to those of $C$ raclinsii, but the ninth pair of legs consisting of two clavate structures united at base, diverging at apex and heset with bristles. Seventh pair of legs decidedly smaller than the sixth.

\section{Craspedosoma stygium Istyel.}

(ienitalia, according to Latzel, of four pairs of structures, one clavatc (probably ninth lecrs) and three pairs of smaller structures between.

Seventh pair of male legs wanting, that is, there are but six paiss in frout of the gronitalia.

Legs +-6 stump-like, though the author of the species doulsts whether this claracter may not be accilental.

\section{Craspedosoma moniliforme Istzel.}

Legrs 3-7 not noticcably crassate, the terminal joint mother thick, pulvinate. Serenth legs reducel, their coxic enlarged, posteriorly with a hirsute process, the pedigerous lamilte powteriorly with a slarp cuneiforn process.

Sinth legrs clavate, more of less evidently jointed, with bristles at the end. Pedigerous lamina nuedinuly producel between the clavate structures and hollowed out in front.

\section{Craspedosoma mutabile Istzel.}

Legs :3- $\boldsymbol{\gamma}$ strongly crassitc, more sparsely hairy, shining, the ternimnl joint compressed, scarcely pulvinate.

Ninth legs in the young five-jointed, attenuate, fuleate; in adult molified into a complex structure apically with long compouml bristles; lasally giving rise to a long flagellum, suygestive as the author says of the flagellum of Iulida, and apuarently indicating a functional difference from other Chordeumidae.

'Tenth and eleventh legs with an inwardly projectingr hamate process from the distal end of the coxie, also a pear-shapeel wart on the hase of the coxe.

It is also stated that the females do not have the legs of the second segment rleveloped, a character apparently of great importance. 'The species has, lowevel, according to Latzel, several varieties and in one of these a female had the usual number of legs. Judging from the American forms it is very remarkable that such a character should not be constant. The difliculty of correctly determining females is very great, especially when the species are incompletely known.

\section{Craspedosoma llavescens I atzel.}

J.cps 3-7 strongly crassate, distal half of the last joint cushioned.

Ninth legs clavate, hirsute, scparated hy a pair of small structures lassally 
broad, apieally clavate, with a pointed triangular transparent lamina rising from the base of each.

Tenth legs much reducel; coxie swollen, on the inner side with a clavate process bearing a bristle, also a small wat below the process.

Eleventh legs normal excepting a small wart on the coxa.

It is to the present genus that the Europenn writers have referred a considerable number of American species. 'l'o us it appetrs that the genus as treated in Europen works is not a natural one, and that the Anerican species are all generically' distinct from any of the European, as far as the sexual chatacters of either are sufliciently known to give basis for an opinion. T'o judge by the characters of the ninth male legs the European forms are all more diverged from the primitive than any of the American, and the grenter complexity of the genitalia in most of them is in accordance with such an idea.

HA ASIA. Bollman, 1893 (as subgenus).

Bulletin Xo. 46, L'. S. N. MIuscum, p. 1 is.

Jiyes entircly alsent.

Antenue slightly elarate, slender, much longer than the wilth of the boly, the seventh joint longer than the sixth.

Segments with exterior two pairs of sete approximate, rather large.

Legs very slender and densely hirsute.

The establishment of the subgenus appears somewhat premature, as both species placed under it are incompletely clescriberl. Craspelosoma troglodytes Latzel, is known only from a femalc specimen, and no characters of generic value are stated except the above. Craspedosoma mamillatum was describec from a male specimen but only at lough sketch of the genitalia is given. From this it would appear that like the open air species of Cras. peclosoma the ninth male legs are reducel to a single joint, without a claw. If this is the case, and if troglodyles and mamillatum are congeneric, Haasia will prove valid.

CHORDECMA ('. I. Koch, 18.7.

System der Myrriap., p. 51, also p. 12.4.

Fyes well develnyel, of numerous weelli $(2 \pi-2 x)$ arrangel in trimgular matches.

Antemna very long, twice the disaneter of the bexly, slender, thirt joint longest.

Segments without arrina; sete and tuberdes nearly obsolete, somewhat more evident on the pusterior end of the botly. 
Males with 6 aubulatory legs in front of the genitalia and 39 behind. First two pairs of male legs with the last joint pectinately spined.

I.ers 3-6 of male distinctly crassite, the inner side of the last joint tomentosc pulvillate.

Seventh lens of males three-jointed, the basal joint large, produced, the others small clavate; an indistinct very small fonth joint (rudimentary claw?).

Genitalia very complex, the anterior large, somewhat hool-like, with an iucluded lamella; the prsterior pair slender, apienlly bifid. There is present a clavate, distally hirsute structure much resmbling the ninth legs of some of the species of Craspedosoma, but Dr. Iatzel does not so interpret it.

The tenth male leas have also been completely molified for copulatory purjwses, consisting of slendur processes.

In females are but 40 umbulatory legs, and the sternum of the third segment projects ceplanlal covering the genitalia.

The above claracters are from Latzel's description of Chordeuma syluestre, the type of the genus. The description and figures of Verhoeff* differ considerably from those of Latzel, in the shape of the genitalia as well as in that of the seventh and ninth legs.

\section{Chorieuma rhenanum Verhorf.}

Seventlı legs reduced to a single sujumiform joint.

'Tentlı legs also of one joint, irregular in shape, with rounded prominences.

Chordeuma germanicum Verhoeff.

Difler's grently in the genitalia, but has the table-like ninth legs of the other species as figured by Verhoeff.

Chordeuma has, perhaps, nenrer relatives in A merica than the other European genern, as alrealy noted under the genus Casey?. The rudimentary seventh and tenth legs of the males of Chordeuma, as well as other secondary sexual characters, give distinct lines of generic separation.

In sddition to the European genern of Craspedosomatida already noted there hare been described three others, Hyphanturgus of Waga, Megalosoma of Fedrizai, and Prinosoma of Berlese, but these have not been recognized by Latzel and Haase, and stand as synonyms of $A$ tractosoma and Craspedosoma.

WFTEROCHORDETMA Pocock: 1893.

Am. Mus, Storia Sat. d. (icmora XIII, p. 397.

Fyes of numerous ocelli (11) arranged in four transverse rows. Antenuse moleratcly long, thivd and tifth serments longest.

* Berliner Fintom Zeitselur, xxxvi, p. 132 (1891). 
Segnients with broad horizontal enrine, like those of I'olyclesmilix; setigerous tubercles very small, only two pairs observel; surfnce covered with short hairs.

Genitalia composed of the two paiss of legs, of the seventh segnuent, completely ext'snal.

Segments of adult 3:.

Habilat: Knren Hills, Burmah, at 1200-1500 m. altitude.

'This anomalous genus presents several unique features, and its family disposition must lemain a matter of some cloubt until the characters of the legs and mouth-parts are known. No other Craspedosomaticle are known from southem Asia, but the discovery of this form suggests the probuble existence of others in the neighboring regions.

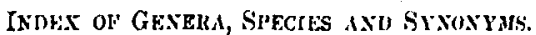

\begin{tabular}{|c|c|}
\hline e & \\
\hline$\ldots \ldots \ldots \ldots \ldots \ldots \ldots \ldots$ & fer. $\ldots \ldots \ldots \ldots \ldots \ldots$ \\
\hline$\ldots \ldots \ldots .88$ & $\ldots \ldots \ldots \ldots$ \\
\hline & rta $\ldots . .$. \\
\hline$\ldots 89$ & bollmani ........ \\
\hline$\ldots 88$ & $\ldots \ldots \ldots \ldots$ \\
\hline$\ldots 75$ & ernta......... \\
\hline$\ldots 53$ & ruri $\ldots \ldots \ldots$ \\
\hline ... it & anilotte ............. \\
\hline$\ldots 89$ & $\ldots \ldots \ldots \ldots$ \\
\hline$\ldots 76$ & $\ldots \ldots$ \\
\hline$\ldots 33$ & crlosomin $\ldots \ldots \ldots \ldots$ \\
\hline . . 33 & inentwm......... \\
\hline esioannulata ....... & lollmani $\ldots \ldots \ldots \ldots \ldots \ldots \ldots$ \\
\hline ktmprodes ............ & corinatum $, \ldots \ldots \ldots \ldots \ldots \ldots, \ldots, \ldots, \ldots$ \\
\hline$\ldots 43$ & 4 cens ......... \\
\hline fiscicol & $l u m \ldots \ldots \ldots \ldots$ \\
\hline imatr......... & $m t u m \ldots \ldots \ldots$ \\
\hline$\ldots 89$ & iliforme . . . . . . \\
\hline eusis ... ...... & ile ..... \\
\hline sseya ....... & $\ldots 68$ \\
\hline$\ldots 8$ & .. \\
\hline .36 & $m$ wii ........... \\
\hline . 91 & nsii........... \\
\hline .. 92 & $i m \ldots$ \\
\hline .83 & $\ldots \ldots$ \\
\hline . . 92 & $\ldots$. \\
\hline .92 & fla \\
\hline . 41 & N.... \\
\hline 43 & fo \\
\hline .51 & ornis.... \\
\hline$\cdot 11$ & . \\
\hline .. 43 & $m u$ \\
\hline .49 & $\ldots$ \\
\hline .50 & Faas \\
\hline .18 & $\cdots$ \\
\hline . 47 & 01 \\
\hline 52 & \\
\hline & \\
\hline
\end{tabular}




\begin{tabular}{|c|c|}
\hline & \\
\hline $\mathfrak{H}^{2}$ & lunatus $\ldots \ldots \ldots \ldots \ldots \ldots$ \\
\hline 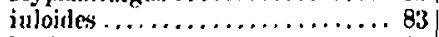 & wyandotle............. \\
\hline ta. $\ldots \ldots \ldots \ldots \ldots \ldots \ldots$ & Spirostrephon ...........41, \\
\hline$r i \ldots \ldots \ldots \ldots \ldots \ldots \ldots \ldots \pi$ & oanmulatus............. \\
\hline$\ldots \ldots \ldots \ldots+63$ & $m \ldots \ldots \ldots \ldots$ \\
\hline$\ldots 47$ & copci $\ldots \ldots \ldots \ldots \ldots \ldots$ \\
\hline ...91 & Striaria $\ldots \ldots \ldots \ldots \ldots$ \\
\hline$\ldots 92$ & $\ldots \ldots \ldots$ \\
\hline . . $88^{!}$ & $\cdots$ \\
\hline$\ldots 52$ & talum $\ldots \ldots \ldots \ldots \ldots \ldots$ \\
\hline .90 & $\because \ldots \ldots \ldots$ \\
\hline .9 & $m i \ldots \ldots \ldots \ldots$ \\
\hline . 68 & $\ldots \therefore$ \\
\hline ..9()! & $m \ldots \ldots \ldots \ldots \ldots$ \\
\hline$\ldots 69$ & $n t u m \ldots \ldots \ldots \ldots \ldots$ \\
\hline . 6s: & גונ \\
\hline & Im \\
\hline$\ldots 92$ & $\ldots \ldots \ldots$ \\
\hline & 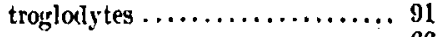 \\
\hline 43 & \\
\hline - 40 & $\operatorname{lin} \ldots \ldots \ldots \ldots \ldots . . . . . .$. \\
\hline$\ldots 36$ & es $\ldots \ldots$. \\
\hline 43,51 & \\
\hline 30 & $\ldots \ldots \ldots \ldots \ldots$ \\
\hline . 88 & $\ldots \ldots \ldots 6$ \\
\hline . 55 & $\ldots \ldots \ldots \ldots \ldots \ldots$ \\
\hline 6 & $\ldots \ldots$ \\
\hline & husted $\ldots \ldots \ldots \ldots \ldots \ldots \ldots$ \\
\hline
\end{tabular}

\section{EXPLANATIOS OF 'THE PLATES. \\ IIATE I.}

Branneria carlnata.

Figr. 1.- Intenya, three clistal jointy, $\chi .56$.

Pseudotremia cavernarum.

Fig. 2--Genitalia of male, anterior view.

Fig. 3.-Same, lateral view.

Fig. 4,-(inathochilarium. C.S. N. MI. No, 42).

Fig. 5. - Antemn, $\times 24$.

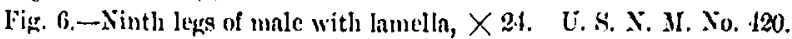

Fir. 7.-Jieventh legs ol male, X24. U. S. N. M. No. 436.

\section{Preudotremia carterenois.}

Fig. R.-Yinth legs of mals, posterior view.

Figr. 9.-Tamella embraced between the ninth legs of male, $X 35$.

Fig. 10.--(ienitalia of male, $\times 50$.

\section{Preudotremia cavernarum.}

Fig. 11.-Body, dorsal view. 


\section{Bcotorpes copel.}

Fig. 12.-Genitalia of male, after Packarl.

Fig. 13.-Same, less magnified; also ninth legs, after Packaıl.

\section{Zygonopus whitel.}

Fig. 14.-Antenna, $\times 27$.

Fig. 15.-First leg of male, $>50$.

Fig. 16. - Second leg of male, $X 50$.

T'LA'PE II.

Zygonopus whitel.

Fig. 17.-Fourth legs of male, $X \tilde{0} 0$.

Fig. 18. -Sixth lexs of male, $X i n$.

Fig. 19.- '-'wolfth leg of male, $X 50$.

Fig. 20.-Genitalia of male, anterior face.

Fig. 21.-Sime, posterior face, also ninth legss.

Trichopetalum album.

Fig. 22. $-\Lambda$ utennac of malc, $\times 105$.

Fig. 23.-First leg of male, $X 105$.

Fig. 23a. - Second legr of male, $X 105$.

Fig. 24.-F'Third leg of male, $X 105$.

Fig. 25.-Fourth le of male, $X 10 \mathrm{i}$.

Fig. 26. -Fifth leg of male, $X 105$.

Fig. 27.-Serenth ler of male, $X 10 \bar{i}$.

Figr. 29.-C'enth legr of malc, $\times 105$.

Fig. 29.-Nomal legr of mile, $\times 105$.

\section{PIATE III.}

Trichopetalum ocellatum.

Figr. 30. - Ilead and three segmeuts, alter Packard.

Fig. 31.-Antemua, after l'uckarl.

Fig, 32.-Wigt, after I'nekard.

Nigr. 33.-Segments, lateral view, after Packart.

Fig. 3.1.-Segnents, rlossil view, nfter l'ackard.

Fig. 35.-Inst six sepments, lateral view, after l'uckard.

\section{Trichopetalum album.}

Firs. $36(X 312), 37(\times: 3,0), 38,39,40(\times 31:), 41 .-A$ pices of male grenitalia, different views, from different specinems.

Fig. 42.- MIale trenitalia, anterion face, $\times 187$.

Figr. 43.-Simme, posterior riew, alse ninth legs.

Fig. 44.-Distal portion of guathochilarium $\times 100$.

Figr. 45.- Eyc.

\section{Trichopetalum comutum.}

Figs. 46, $47(\times 294), 19(\times 333)$. -A pices of malc genitalia, different specimens and rievs.

Fig. 49.-Male genitalium, lateral vitw. 
Fig. 50.- Hye.

\section{Trichopetalum flavidum.}

Trichopetalum nncum.

Fig. 51. -Genitalia of male, anterior face, $\times 169$.

\section{Thlchopetalum lunatum.}

Fig. 52.-Antenma, atter Jurger.

Fig. 53.- lise, after Harger.

Fig. 54,-Male genitalia, after Harger.

\section{PLATE IV.}

\section{Conotyla fischer.}

Fir. 55.- Ileal and tirst three segnents, dowsal aspect.

Fir. 56.,-Same, lateral anject.

Fir. 57.-I ast four sxyments, lateral aspect.

Fig. i8.-1abrum.

Figr. i99.-Distal portion of lanlf of gnathochilarium.

Fig. 60.-Inst four gegments, ventral view.

Fig. 61. - 'Two distal joints of antenna, $\times 50$.

Fig. fi2.-Distal portion of half of gnathochilarium, dorsal face.

Fig. 63. - Cuathochilaritui.

Fig. 64.-Intemna, $\times 2.5$.

Fig. (ij.-First legr of male, $X 2 \mathrm{i}$.

Fig. 66. -Sccond lerr of male, $\times 25$.

Fir. 67.-Third leg of male, $\times 25$.

Fig. 68. - Fourth les of mule, posterior view, $\times 25$.

Fig. 69. -Fifth lew of male, posterior riew, $X 25$.

Fig. 7ill.-Seventlı lexr of male, anterior view, $X$. 25.

Fig. 71.-l'rocess of the fourth joint of the seventh leg, more magnified.

Fig. 72.- Male grenitalia, nnterior view.

Fig. 73. - Ventral portion of segments 5-8, male genitalia, and lasal joints of lergs, lateral view.

Fig. it.- Yale genitalia, lateral view.

Fig. 75. - Anterior pair of male genitalia, anterior view.

\section{l'IATE V.}

\section{Conotyla fischeri.}

Fig. 76.-Tenth pair of legs of nitle, $\times 25$.

Fig. i7. - Yleventh pair of legs of male, $X 25$.

Fig. $7 x$, Twelfth pair of legs of male, $X 37$.

\section{Conotyla bollmanl}

Fig. 79.-DIale gentalia, anterior view, Li. S. N. II. No. 419.

Fig. 80. - Same, lateral view.

Fig. 81.-Right eye.

Fig. 82.-Left eye.

Fig. 83.-Antenna, $\times 2$ i. 
Fig. 84.- Ilead and first eight segments.

Fig. 85. - Last six segments.

Fir. 86. - First leg of male, $X 45$. U. S. S. M. No. 443 .

Fig. 87.--Second leg of male, $>28$.

Fig. 88.-Third leg of male, posterior view.

Fig. 89.-Fourth leg of male, posterior vicw, $x$ 25.

Fig. 90.--Serenth ley of male, anterior view.

Fig. 91.-T'enth ley of male, posterior view, $\times \mathbf{2 5}$.

Fig. 92.-Eleventh leg of male, posterior vicw, $X, 25$.

Fig. 93.-Normal leg of male, anterior view.

Fir. 94.-Iongitudinal section of spine, drawn from C. fartheri.

\section{PIATEE VI.}

\section{Conotyla atrolineata.}

Fig. 95.,-Antenna, $\times 57$.

Fig. 96.-Male grenitalium of posterinr pair, $\times 127$.

Fig. 97. - Nale genitalium of anterior pair, $\times 127$.

Fig. 98. - Ninth ler of male, $\times 16$.

Fig. 99.-Fye, drawn from Winona specimen.

Fig. 100.-Eye, irawn from Glacier, B. C., specinten.

\section{Conotyla wyandötte.}

Fig. 101.- Fye. The photo-engravers omitted the number on the plate. The figure is alsove 100 , at the right-hand margin of the plate.

Fis. 102.-Antenna.

\section{Conotyla lelbergi.}

Pig. 103.-(inathechilarium.

Figr. 104.-Eye.

\section{Conotyla glomerata.}

Fig. 104a.-Antenna and eye, after Harger.

\section{Cleidogona mexdcana.}

Figrures copied from Sauswure and Humbert.

Fig. 105. - Ginathochilarium.

Fig 10i,-Sesment, rental view.

Fig. 107.-Antemu.

Fig. 108. - Posterior part of losly, lateral view.

Fig. 109. -Same, dorsal view.

\section{Cleldogona major.}

Fig. 110.-First pail of legs of male, $\times 16$.

Fig. 111. Siceond pair of leges of male, $\times 16$.

Figr 112.-Third patir of legx of nule, 16.

Fin. 113,-Fourth pair of legs of male, $X 16$.

Firr. 114.-Fifth piir of legs of male, $X 16$.

Fir. 115. Sixth pair of legrs of male, $\times 16$.

Axwas N. Y. ACul. Sc.r., IX, Nov., 189;.-7 
Fig. 116.-S Seventh pair of legs of malc, $: 16$.

Fig. 117. - Sinth pair of legs of male, $\times 16$.

Pig. 118.-Tenth pair of legs of male, $\times 10$.

\section{PIATE VII.}

Cleldogona major concluled.

Jig. 119.-Eleventh pair of lears of male, $\lambda 16$.

Fig. 120.-Twelf th pair of legs of male, $\times 16$.

Vig. 121.-Thirteenth jair of legs of male, $X 16$.

Fig. 122.-Twentietl pair of leps of male, $\times 16$.

Figr. 123. -Fiftith (last) pair of legs of male, $\times 16$.

Fir. 124, $-A$ pian joints of second leg, $X 1 \$ 3$.

Fig. 125.-Antemn, $\times 31$.

Fif. 126.- - d pex of sixth joint of second leg, $\times 160$.

Fig. 127.-Niutl ler of male.

Fig. 128. -Male genitalia lateral view, $\times 46$.

Fig. 129.-Apices of sune, apieal view, $\times 46$.

Fig. 130.-Male genitalia, posterior view $\times 16$.

Fig. 131.-Legs 7-12, drawn in situ.

Fir. 132.-Ginathochilarium.

Jig. 133.-Head, lateral view.

Fig. 134,- - Head and six begments, dorsal view.

Fig. 13ij.--Last tive segments, lateral view.

Fig. 136.-Sime, dorsul view.

Fig. 137.--Pre-anal scale.

\section{PIJTE VIII.}

\section{Cleldogona casioannulata.}

Fig. 13\%.-Genitalia of male, lateral view.

Fig. 139. - Same, dorsal (anterior view).

Fig. 140.-Ninth leg of male.

Fig. 141.-Eleventh ley of male.

Fig. 142.-Twelf th ler of male.

Fig. 143.-Antenua.

'The above six figures were driwn from specimens collected near the Cutholic Lniverkity, Washington, D. C.

Fig. 14.-Iast joint of ninth male leg.

Jig. 145. - Sinth legs, $X 25$.

Fig. 146,-Anterior aspect of genitalia.

Fig. 147.- Lateral view of genitalin.

Fig. 148.- l'osterior view of genitalia.

Figures 14l-1/4 were drawn from Sational Mfusemu mnterial, with no record of locenlity.

Firg. 119.-Xintlı les.

Fir. 150.-(ienitalia; this and the preceling figure after MeNeill. His material was collected in Monroe Comity, Indiann. 


\section{Cleidogona fustis.}

[ig. 151. - Afale genitalia, anterior view.

Fig. 152.-Sane, lateral view.

Fig. 153.-Sime, drawn from :nother specimen and at a diflient angle.

lig. 154.-First leg of miale.

Fig. 155.- Second leg of male.

Fir. 156.-Seventh leg of male.

Fig. 157.-Tenth leg of male.

Fig. 158.-Eleventl leyr of male.

\section{I'LATE, IX. \\ Cleidogona forceps.}

Fig. 159,-. Iale grenitalia, lateral view.

Fig. 160.-Same, anterior view.

Fig. 161.-Sime, posterior view.

Figr. 162.-Ninth ler of male, $\times 30$.

Fig. 163.-A pical portion of same, $\times 10 \mathrm{z}$.

\section{Cleidogona laminata.}

Fig. 164.-Genitalia and legs 9-12, drawn in xilu.

Fir. 165. - Nale genitalia, anterior view.

Fig. 166.-Same, posterion view.

Fig. 167.-Ninth ley of male, posterior view.

I'ig. 168. - Same, anterior vicw.

Fig. 16\%.-Antemn, $X$ 31.

Fig. 170.--'T'enth legs of male.

Fig. 171.-Eleventh legs of malc.

Fig. 172.- - Intenna.

\section{Bactropus conifer.}

Fig. 173.-Gnatlochilarium, $\times 105$.

Fing. 17.1.-Centatia of male, anterior view, with ninth legs.

Fig. 17i). - $\lambda$ pical joints of ninth legr of male.

Fig. 176,-Taist two segments, lateral view.

\section{PLATE X.}

\section{Underwoodia iuloldea.}

Fig. 177.-Fye and part of antennal socket.

Fig. 178. - Antemn, $X 8()$.

Fig. 179.-Sceond pair of legrs of tenalc.

\section{Underwoodia polygama.}

Fig. 180.-First legs of male, $X$ io).

Fig. 181.-Second legrs of male, prosterion view, $<$ iv).

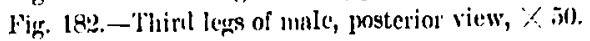

Fig. 1*3.-Fourth legs of male, $x$ stl.

Fig. 184.-Fifth legs of male, $x .50$. 
Fig. 185,-Eleventh legs of male, $X 45$.

Fig. 186.- - Inle genitnlin and ninth leg, pasterior view.

Fig. 187.-Same, anterior view.

Firg. 148. - Gnathochilarium.

Fiz. 189.-. Antemna, $X 57$.

Fig. 190.-Distal joints of antenna.

\section{PLATE XI.}

\section{Caseya heteropis.}

Fig. 191.- IIsid and first six segments, lnteml riew, $\times 10$.

Fig. 192.-Uhel, anterior view, $\times 25$.

Fig. 193.- Eyc, antennal socket, margin of ceplalic plate und post-antonual urgan, the bast indiciter by the small ring immediately lelow the ocelli.

Fig. 19. - I Labrum.

Fig. 195.-Guatlonchilarium.

Pig. 196.-Lingual lolke, lingual lamina with conic sense organs, and triclentate styliform process, $\times 105$.

Fig. 197.-Antemm, $\times 25$.

Fig. 199.-Fint ler of male; the specimen was injured, $\times 25$.

Fig. 199.-Second legs of male, posterior view, $\times 2 j$.

Fig. 2(0).-l'roxinal portion of same, anterior view, $\times 105$.

Fig. 201. - Third legs of male, posterior view, $X 25$.

Fig. 202.-Proxinal pertions of sume, anterior view; $X, 23$.

Fig. 203. - siane, $\times 105$.

Fig. 201. - Fourth legs of male, posterior view, $\times 25$.

Figr. 2015.-Fifth legrs of male, anterior view, $X 25$.

Figr. 206.-CSixth lecgs of male, anterior view, $X 25$.

Fig. 20\%.-Serenth lege of malc, anterior view, $X 2 \bar{i}$.

Fig. 208,-I'roximal joints of gamc, posterior view, $X 25$.

\section{PLATE XII.}

\section{Caseya heteropus.}

Fig. 20!),-1'ortion of lesal joint of seventh leg of male, anterior view; $X$ 1(i.).

Fig. 210.- Pasal joints of tenth leg of male, anterior view.

Fir. 211.-Sante leas, posterior vien; $\times 25$.

Fir. :212.- Elleventh legr of male, anterior view.

Fig. 213.-Twelfth leg of male, josterior view.

Fig. :1. - Yommal leg of male, anterior, $x: 31$.

Fig, 215. - Nale penitalia and ninth legs, ventml (anterior) view, drawn in silu,

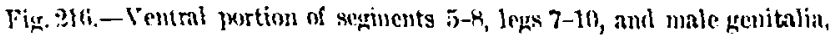
littral view, drawn in sillu, $\times 25$.

Figr. $21 \%$.-Male gonitalium, median view. The small unshaded part near Hile midille is non to the other side.

Fin. 21, - Ninth legs of male, anterior view, $x 40$.

Pig. 219. - Sinth legs of male, posterior view, $\times 40$. 